\title{
Hydrogeochemical characterisation and appraisal of groundwater suitability for domestic and irrigational purposes in a semi-arid region, Karnataka state, India
}

\author{
M. A. Mohammed-Aslam ${ }^{1}$. Syed Shams Rizvi ${ }^{1}$ (D)
}

Received: 24 May 2020 / Accepted: 21 October 2020 / Published online: 10 November 2020

(c) The Author(s) 2020

\begin{abstract}
Hydrogeochemical investigations have been carried out in a semi-arid region of Aland taluk of Karnataka State, India. The analysis has been done to examine the quality of groundwater for drinking, domestic and irrigational purposes. In this concern, thirty-two groundwater samples were collected in pre-monsoon (April 2016) and post-monsoon season (November 2016), from the different location within the study area. These samples have been further analysed for different ions such as $\mathrm{CO}_{3}{ }^{2-}, \mathrm{HCO}_{3}{ }^{-}, \mathrm{NO}_{3}{ }^{-}, \mathrm{Ca}^{2+}, \mathrm{Mg}^{2+}, \mathrm{Na}^{+}, \mathrm{K}^{+} \mathrm{Fe}^{2+}, \mathrm{SO}_{4}{ }^{2-}, \mathrm{Cl}^{-}$and $\mathrm{F}^{-}$to evaluate the hydrochemical behaviour with SSP (sodium soluble percentage), SAR (sodium absorption ratio), \% $\mathrm{Na}$ (percentage sodium), RSC (residual sodium carbonate), KR (Kelly's ratio), PI (permeability index) and MH (magnesium hazards). These positive and negative ions have been further correlated with the maximum annual rainfall within the study area to find out the variations between these ions for the precipitation. Suitability of groundwater for drinking purposes around the catchment was not suitable except in a few places. Irrigational suitability of groundwater showed that the water is within the limit for irrigation except in a few locations. Wilcox diagram depicts that $90 \%$ of the pre-monsoon samples and $65 \%$ of the post-monsoon samples fell into excellent to good category zone. US salinity diagram explains that $71 \%$ of pre-monsoon samples belong to medium-salinity-hazard to low-sodium-content zones, whereas $50 \%$ of post-monsoon samples fall into high-salinity-hazard to low-sodium-content zone. Gibbs's plot showed that the water-rock processes control the geochemistry of the Aland region in both monsoon seasons. Chadha's diagram depicts that $56.25 \%$ of the groundwater samples fall under the subfield of $\mathrm{Ca}^{2+}-\mathrm{Mg}^{2+}-\mathrm{Cl}^{-}$water type with permanent hardness during pre-monsoon season, whereas $50 \%$ of groundwater samples falls under the subfield of $\mathrm{Ca}^{2+}-\mathrm{Mg}^{2+}-\mathrm{HCO}_{3}^{-}$water type with temporary hardness during post-monsoon season.
\end{abstract}

Keywords Groundwater hydrochemistry · Quality analysis · Irrigational suitability · Domestic suitability · Rainfall · Correlation $\cdot$ Semi-arid region

\section{Introduction}

The quality of water is an essential factor for controlling water management studies. Generally, anthropogenic and geogenic activities are responsible for groundwater

M. A. Mohammed-Aslam and Syed Shams Rizvi both the authors have equally contributed throughout the work.

M. A. Mohammed-Aslam

maslam.in@gmail.com

Syed Shams Rizvi

shamsrizviamu@gmail.com

1 Department of Geology, Central University of Karnataka, Kalaburagi, Karnataka, India contamination. Industrial, agricultural and domestic wastes, rainfall pattern and infiltration rate are also responsible for the deterioration of groundwater quality. Once a groundwater system is contaminated, it continues for many years because of the very slow movement of water in them. It may become challenging to monitor their quality by removing the pollutants from the contaminated aquifer (Devi et al. 2009). The degrading groundwater quality has become a severe universal issue for sustainable development (Adimalla and Jianhua 2019; Li et al. 2019), and therefore, it is very important to understand the hydrogeochemical characteristics of groundwater for sustainable resource development and governance (Huzefa et al. 2020). Subsurface water is mostly limited due to the scanty precipitation, which leads to high evaporation and runoff, especially in arid and semi-arid 
regions (Kadam et al. 2020; Camacho Suarez et al. 2015). Almost one-tenth of worldwide diseases occur due to polluted water and poor sanitation (Fewtrell et al. 2007) and there are nearly 2.5 billion of the population without access to clean water (WHO 2011).

The quality of groundwater is controlled by geology, recharged water, water-soil interaction, recharge and discharge conditions of the area, soil-gas interaction and reactions occurring in the aquifer (Biswal and Kalita 2009; Selvakumar et al. 2014). It also plays a significant role in agricultural production and human health condition (Mohammed-Aslam et al. 2016). Polluted drinking water naturally affects the soil-crop-water system. If the deterioration of water quality is not checked at the right time, it will not be suitable for many purposes (MohammedAslam et al. 2016). Geochemical studies generally deal with chemical parameters and its portability for drinking, irrigation and industrial purpose. Sodium absorption ratio (SAR), high salinity and percentage sodium $(\% \mathrm{Na})$ play a significant role in the ranking of quality of groundwater for irrigational purposes. Evaluation of hydrochemical quality of groundwater reveals the interaction groundwater with the surrounding rocks and minerals (Gibbs 1970). The demand of freshwater resources has been increased in the Aland region mainly due to the population growth and severe agricultural activities. Moreover, the industrial establishments are attracted in this region, due to special schemes in Hyderabad-Karnataka region, wherein this area is located. Therefore, it has become essential to manage the groundwater deployment in the area. The goals of this study are to evaluate the hydrochemical behaviour and represent the appropriate picture of present water quality in the study region through SSP, SAR, RSC, KR, PI, MH and $\% \mathrm{Na}$ values with irrigational and domestic suitability of water quality using US salinity diagram, Wilcox diagram, Gibb's plot and Chadha's plot.

\section{Study area}

Amarja Reservoir Catchment comes under Aland Taluk of Northern Karnataka region. The region is well known for water scarcity. It covers an area of $544.76 \mathrm{sq}$. km and surrounded between latitude $17^{\circ} 50^{\prime}-9^{\prime \prime}-\mathrm{N}$ to $17^{\circ} 72^{\prime}-20^{\prime \prime}-\mathrm{N}$ and longitude $76^{\circ} 45^{\prime}-8^{\prime \prime}$-E to $76^{\circ} 55^{\prime}-20^{\prime \prime}$-E (Fig. 1). The study area comes under semi-arid provinces consisting mainly of basalt with intertrappean beds at some places (Rizvi and Mohammed-Aslam 2018, 2019). The region also contains deep black soils that have been derived from Deccan traps (Rizvi and Mohammed-Aslam 2018, 2019). The summer season is from February and June. The south-west monsoon is from June to September. The month of December comes under the coldest month, having a temperature variation $29.5^{\circ} \mathrm{C}$ to and $10^{\circ} \mathrm{C}$ (CGWB 2012). In the peak of summer, the temperature was found raised to $45{ }^{\circ} \mathrm{C}$. The relative humidity is about $26 \%$ in the summer season and increases by up to $62 \%$ in the winter period (CGWB 2012). The area receives an average annual rainfall of about $777 \mathrm{~mm}$, while the minimum yearly rainfall is $342 \mathrm{~mm}$ and the maximum yearly rainfall is $1270 \mathrm{~mm}$ (CGWB 2012).
Fig. 1 Sampling location map of the study area

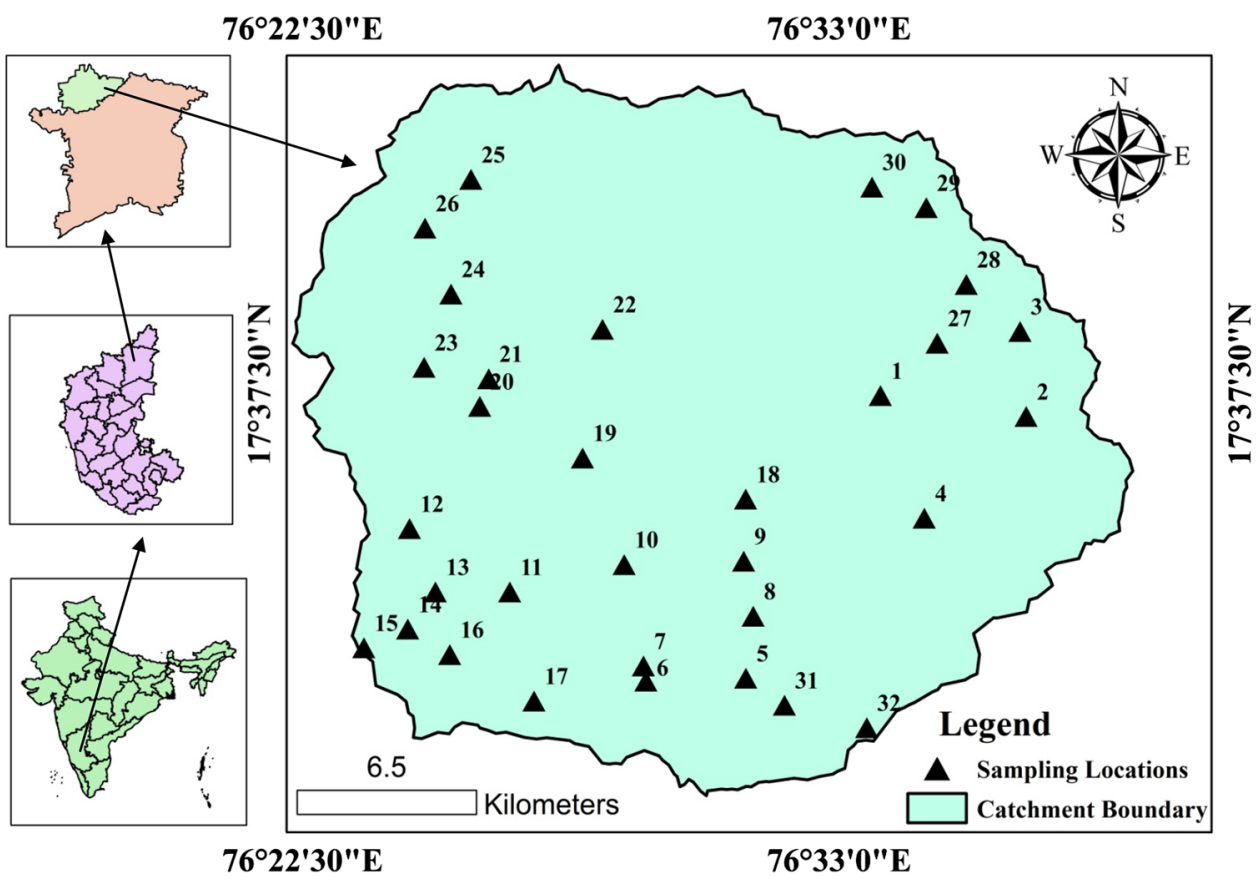




\section{Data collection and methodology}

A total number of 32 samples were collected from the bore wells and open wells in the study area (Fig. 1). Sampling has been done in both pre-monsoon (April 2016) and postmonsoon (November 2016) seasons. Drinking water samples were collected with high precautions, ensuring that there is no contamination takes place during the time of sampling. Intensive care has been taken during the collection of the water sample from freshwater resources in one-litre bottles. Geographical coordinates and elevation at each location were recorded by using GPS (global positioning system). ArcGIS 10.3 software has been used in the study for preparing the geospatial maps. The geospatial maps of physicochemical parameters were prepared to analyse the distribution pattern within Amarja reservoir catchment by using this software. TDS, $\mathrm{pH}$ and EC test were done at the field itself by using TDS, $\mathrm{pH}$ and electrical conductivity meters. The analyses of the rest of the parameters were performed in the laboratory within $24 \mathrm{~h}$ after the collection of the samples. Magnesium, calcium, sodium, potassium, chloride, fluoride, alkalinity, nitrate, sulphate and total hardness have been analysed for the water samples. The analysis was done based on BIS standards (2012).

\section{Result and discussion}

Geochemical characterisation has been evaluated based on sodium soluble percentage, sodium absorption ratio, residual sodium carbonate, percentage sodium, permeability index, Kelly's ratio and magnesium hazards. US salinity diagram was used to categorised salinity hazard zone, whereas water-rock interaction was done based on Gibb's diagram. Chadha's plot was used to understand the hydrochemical facies of groundwater within the study region. The details of the analysed results are shown in Tables 1 and 2, respectively.

\section{Groundwater suitability for drinking purposes}

\section{pH}

The $\mathrm{pH}$ of analysed samples varies from 7.16 to 8.88 in the pre-monsoon season, whereas it ranged from 7.30 to 8.75 during the post-monsoon season. The spatial distribution map of $\mathrm{pH}$ of both seasons is shown in Figs. 2 and 3 . According to the BIS guideline (2012), the permissible limit of $\mathrm{pH}$ is in the range from 6.5 to 8.5 and $9.38 \%$ of the samples during pre-monsoon, whereas $3.12 \%$ during the post-monsoon season were exceeded the maximum permissible limit. Though $\mathrm{pH}$ has no direct effect on human health, all biogeochemical reactions are sensitive to the variation of pH (Subba Rao and Krishna Rao 1991).

\section{Electrical conductivity}

Electrical conductivity values in the study area range from 168 to $1479 \mu \mathrm{S} / \mathrm{cm}$ in the pre-monsoon season and it varies from 181 to $1100 \mu \mathrm{S} / \mathrm{cm}$ during post-monsoon. $40.63 \%$ of the samples have shown conductivity values less than 500 $\mu \mathrm{S} / \mathrm{cm}, 50 \%$ were in between 500 and $1000 \mu \mathrm{S} / \mathrm{cm}$, whereas $9.37 \%$ of the groundwater samples have conductivity value more than $1000 \mu \mathrm{S} / \mathrm{cm}$. Higher amounts of electrical conductivity depend upon temperature, concentration and type of ions present in groundwater (Adimalla and Venkatayogi 2018). Geospatial mapping of the conductivity of both monsoon seasons is shown in Figs. 4 and 5.

\section{Total dissolved solids (TDS)}

Higher concentrations of dissolved solids increase the density of water and influence the osmoregulation of freshwater organism (Sharath et al. 2018). The lower concentration of TDS in groundwater is due to the repeated dilution through rainfall and influent nature of surface water bodies (Mohammad Muqtada et al. 2018). TDS values of pre-monsoon season were found in the range from 108 to $947 \mathrm{mg} / \mathrm{L}$ and showed the variation from 116 to $704 \mathrm{mg} / \mathrm{L}$ during postmonsoon. The acceptable limit of TDS in groundwater is $500 \mathrm{mg} / \mathrm{L}$ as per BIS 2012 . Only $21.88 \%$ of the groundwater samples were exceeded the permissible limit during pre-monsoon season, whereas $34.38 \%$ of the samples were above the limit during post-monsoon season. The spatial distribution map of TDS of both the seasons is shown in Figs. 6 and 7. The variation in TDS values may also occur due to Geogenic activities in the region.

\section{Calcium and magnesium}

Calcium in the groundwater of the study area varies from 16 to $368.16 \mathrm{mg} / \mathrm{L}$ in the pre-monsoon season, whereas 22.4-201.6 mg/L was recorded during post-monsoon season. Only $9.37 \%$ of samples were exceeded the permissible limit in the pre-monsoon season, whereas $3.12 \%$ were above during post-monsoon season. Spatial distribution map of calcium of both seasons is shown in Figs. 8 and 9 . The presence of a large amount of carbon dioxide may increase the solubility of calcium up to $200-300 \mathrm{mg} / \mathrm{L}$ with an availability of the bicarbonate (Hem 1985). Magnesium in the groundwater of the study area is varying from 0 to $92.15 \mathrm{mg} / \mathrm{L}$ during pre-monsoon season, whereas, during

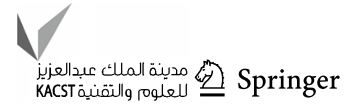


丞

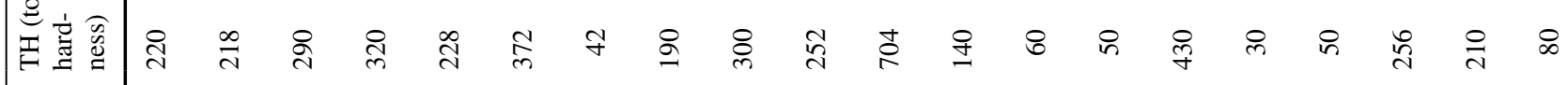

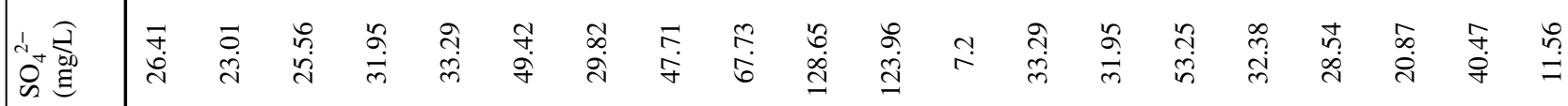

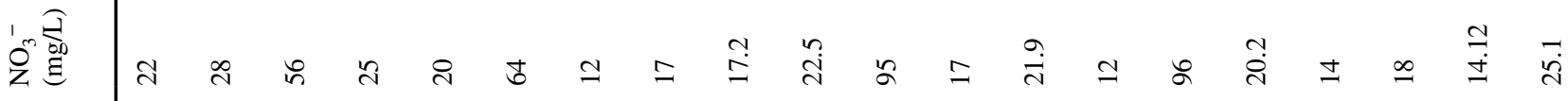

厸 莺

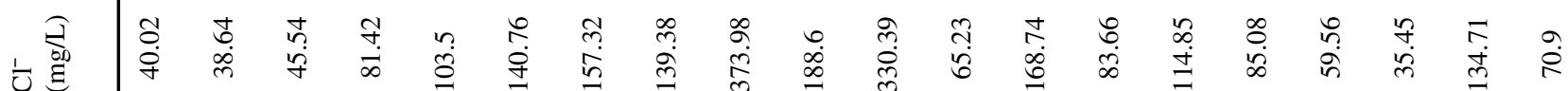

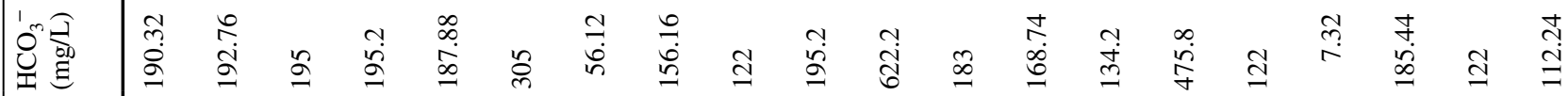

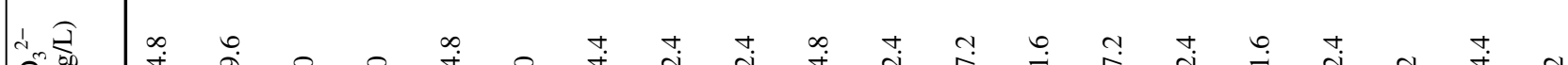

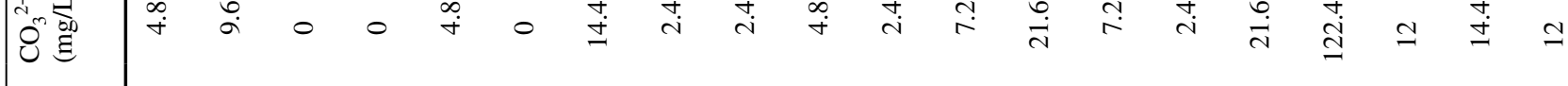

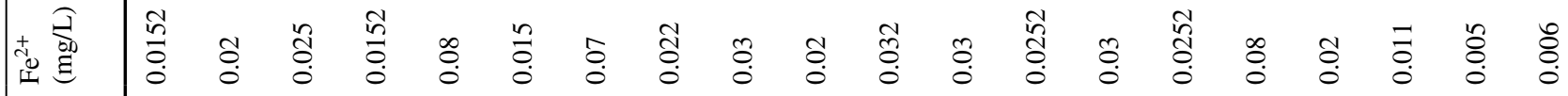

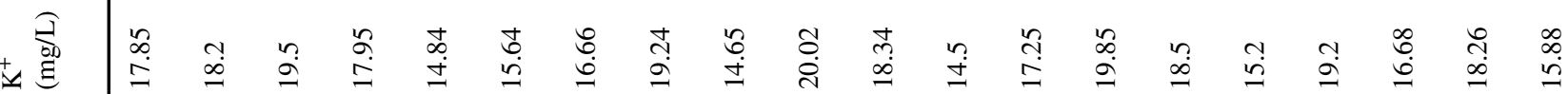

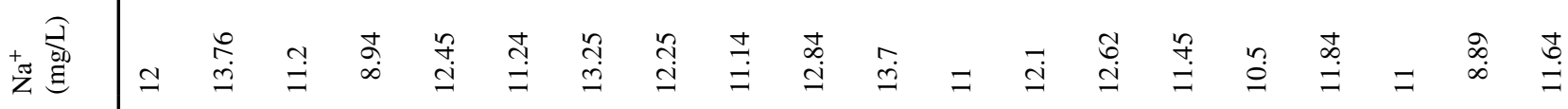

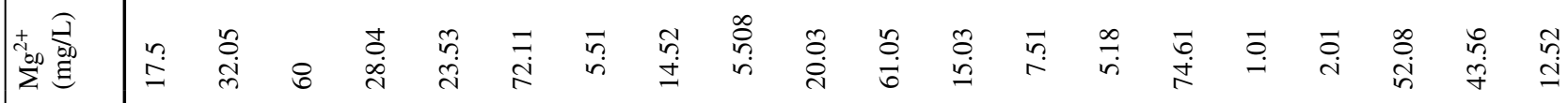

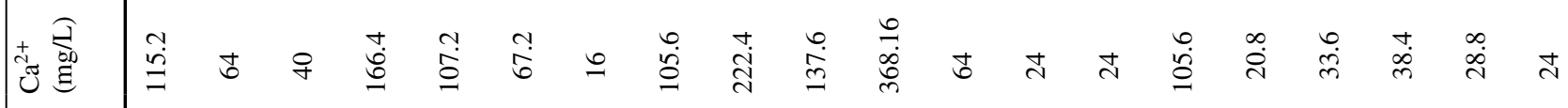

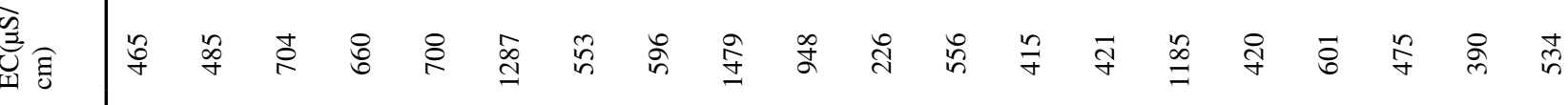

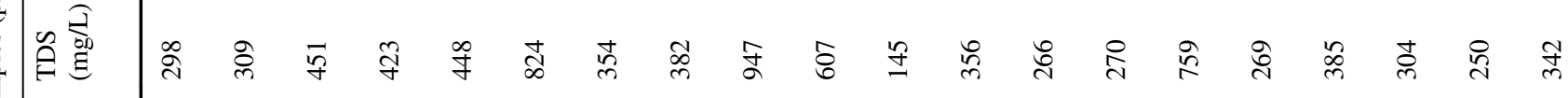

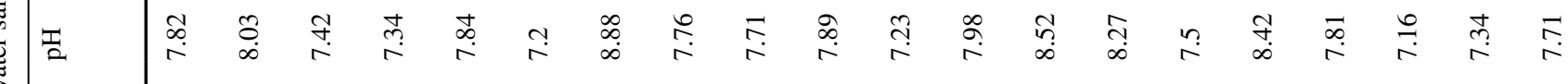

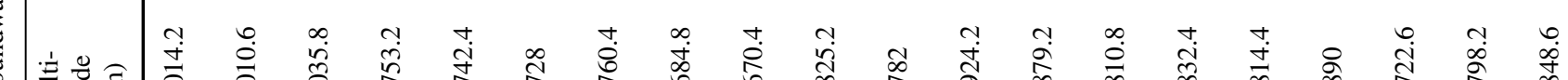

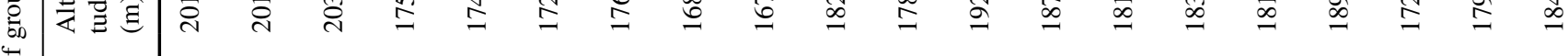

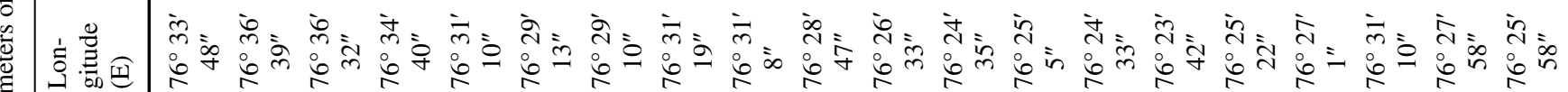

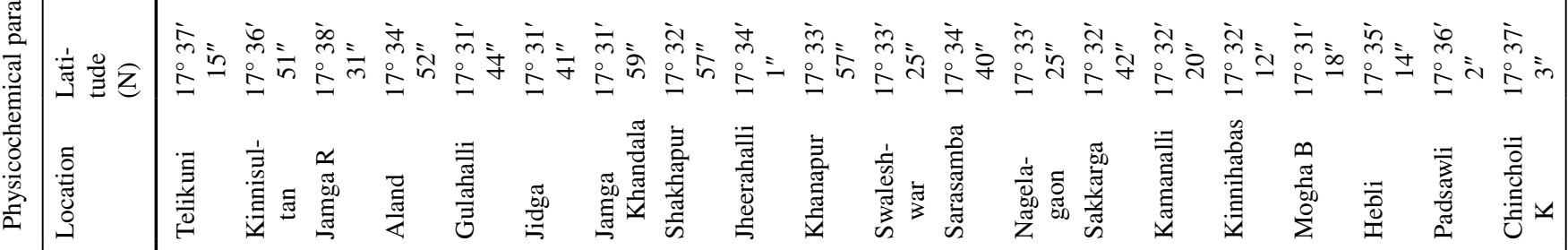




\begin{tabular}{|c|c|c|c|c|c|c|c|c|c|c|c|c|}
\hline 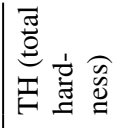 & 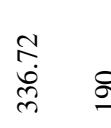 & 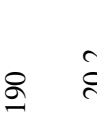 & ก้ & 8 & $\stackrel{\curvearrowleft}{n}$ & $\stackrel{0}{ \pm}$ & $\underset{\sim}{\sim}$ & సి & స్తి & I & 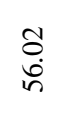 & $\underset{P}{\stackrel{P}{f}}$ \\
\hline & 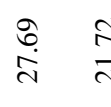 & 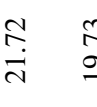 & $\stackrel{\overbrace{}}{\stackrel{9}{2}}$ & $\stackrel{?}{\vec{v}}$ & $\begin{array}{l}\infty \\
\grave{i}\end{array}$ & $\underset{\vec{i}}{\vec{a}}$ & ín & $\begin{array}{l}\hat{\infty} \\
\dot{\gamma}\end{array}$ & $\begin{array}{l}\infty \\
\stackrel{0}{+} \\
+\end{array}$ & $\underset{\infty}{\vec{j}}$ & $\begin{array}{l}n \\
\tilde{8} \\
\stackrel{0}{0}\end{array}$ & $\hat{a}$ \\
\hline & $\stackrel{n}{m}$ & ભે & פे & 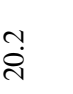 & $\check{a}$ & F & ㄱ. & กิ & $\stackrel{2}{2}$ & 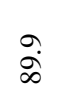 & $\stackrel{\sim}{\underset{I}{ \pm}}$ & $\begin{array}{c}n \\
\ddot{b}\end{array}$ \\
\hline & $\stackrel{8}{\stackrel{8}{+}} \stackrel{7}{-}$ & 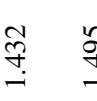 & 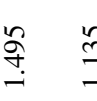 & $\stackrel{n}{\rightleftarrows}$ & $\stackrel{n}{\stackrel{n}{q}}$ & $\stackrel{n}{\stackrel{n}{q}}$ & $\stackrel{\infty}{m}$ & 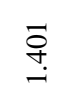 & $\underset{f}{\stackrel{f}{Z}}$ & $\stackrel{f}{-}$ & $\begin{array}{l}+ \\
b \\
0 \\
0\end{array}$ & $\stackrel{\infty}{\stackrel{\infty}{=}}$ \\
\hline & $\begin{array}{l}\infty \\
\dot{m} \\
\vec{m}\end{array}$ & $\begin{array}{ll}\hat{6} \\
\text { sิ }\end{array}$ & 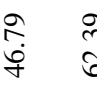 & ले & 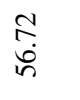 & $\underset{n}{\stackrel{5}{n}}$ & $\begin{array}{l}\dot{U} \\
\dot{ \pm} \\
\dot{I}\end{array}$ & $\begin{array}{l}\text { ర్ } \\
\text { î }\end{array}$ & $\stackrel{9}{\stackrel{7}{q}}$ & 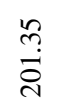 & 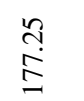 & $\frac{m}{\vec{n}}$ \\
\hline 8 & 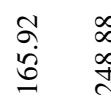 & 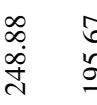 & 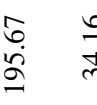 & $\begin{array}{l}\circ \\
\dot{+} \\
\dot{m}\end{array}$ & $\begin{array}{l}0 \\
\infty \\
\stackrel{0}{n}\end{array}$ & ֻุ' & $\begin{array}{l}+ \\
\dot{b} \\
\dot{J}\end{array}$ & $\stackrel{\circ}{\stackrel{\sim}{े}}$ & $\underset{\stackrel{d}{0}}{\underline{\sigma}}$ & 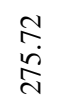 & 苛 & 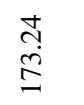 \\
\hline & $\stackrel{\sim}{\sim}$ & $\simeq$ & $\begin{array}{l}\mathscr{\infty} \\
\stackrel{+}{+}\end{array}$ & $\stackrel{r}{r}$ & $\simeq$ & 0 & $\stackrel{\grave{i}}{i}$ & $\stackrel{\infty}{+}$ & $\stackrel{\sim}{\sim}$ & 0 & $\simeq$ & 0 \\
\hline 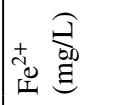 & $\underset{0}{8}$ & \begin{tabular}{ll}
$\frac{t}{0}$ & \multicolumn{2}{c}{} \\
\\
0
\end{tabular} & 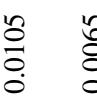 & : & $\begin{array}{l}\stackrel{0}{0} \\
\stackrel{0}{0}\end{array}$ & $\stackrel{8}{0}$ & ڤั & $\stackrel{t}{8}$ & $\begin{array}{l}n \\
\vdots \\
0\end{array}$ & ஜ̊̊. & \&̊. & : \\
\hline & $\stackrel{\simeq}{\check{L}}$ & 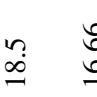 & 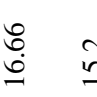 & $\begin{array}{l}\text { בֶ } \\
\text { ñ. }\end{array}$ & $\begin{array}{l}\tilde{n} \\
\stackrel{0}{0}\end{array}$ & $\stackrel{\Upsilon}{2}$ & $\stackrel{n}{=}$ & $\stackrel{+}{\infty}$ & $\begin{array}{l}\infty \\
\infty \\
\infty \\
\infty\end{array}$ & $\begin{array}{l}\stackrel{\wp}{q} \\
\infty \\
\rightarrow\end{array}$ & 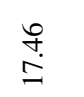 & $\begin{array}{l}\stackrel{a}{\alpha} \\
\dot{0}\end{array}$ \\
\hline & $\begin{array}{ll}\infty & \infty \\
& =\end{array}$ & $\stackrel{\infty}{\stackrel{\infty}{\Xi}}$ & 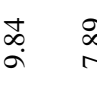 & $\stackrel{\infty}{\stackrel{\infty}{r}}$ & $\approx$ & $\stackrel{n}{\stackrel{n}{q}}$ & $\stackrel{\infty}{\stackrel{\infty}{=}}$ & $\cong$ & $\underline{n}$ & $\stackrel{\sim}{2}$ & $\stackrel{\circ}{=}$ & $\stackrel{n}{=}$ \\
\hline 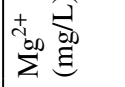 & 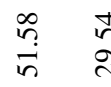 & 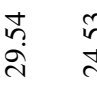 & $\begin{array}{l}n \\
\stackrel{n}{\sim} \\
\dot{N}\end{array}$ & $\sqrt{n}$ & $\begin{array}{l}\dot{d} \\
\stackrel{\sim}{0}\end{array}$ & $\begin{array}{l}\text { ֻે } \\
\text { ते }\end{array}$ & 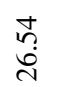 & 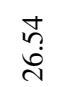 & $\begin{array}{l}n \\
\stackrel{n}{n}\end{array}$ & $\stackrel{n}{\stackrel{n}{i}}$ & 0 & $\underset{\substack{0 \\
\infty}}{\infty}$ \\
\hline & in is & 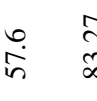 & $\underset{\infty}{\widehat{\infty}}$ & $\stackrel{\infty}{+}$ & $\stackrel{\sim}{n}$ & $\underset{f}{\dot{q}}$ & $\stackrel{\stackrel{+}{ \pm}}{=}$ & $\stackrel{0}{\stackrel{0}{a}}$ & $\stackrel{+}{\infty}$ & $\stackrel{\stackrel{2}{a}}{a}$ & $\stackrel{\infty}{+}$ & $\stackrel{\infty}{\stackrel{+}{\Xi}}$ \\
\hline 氖 छิ & $\stackrel{2}{2}$ & ठิे & $\frac{n}{n}$ & ồ & $\tilde{\mathscr{\gamma}}$ & $\stackrel{\infty}{\circ}$ & $\vec{\infty}$ & $\stackrel{\infty}{i}$ & $\hat{\infty}$ & $\stackrel{\infty}{\varrho}$ & 官 & $\stackrel{\vartheta}{\forall}$ \\
\hline E & $\stackrel{\circ}{n}$ & ชิ & ల్ల & $\stackrel{\infty}{\sim}$ & $\vec{\sim}$ & 을 & है & $\infty$ & $\stackrel{\sim}{m}$ & $\stackrel{\infty}{\varrho}$ & స్ర & s \\
\hline 贾 & $\stackrel{i}{i}$ & 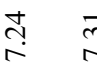 & $\vec{m}$ & $\underset{\substack{\text { T. }\\
}}{ }$ & $\underset{\bullet}{\circ}$ & $\stackrel{+}{n}$ & $\stackrel{\text { ? }}{\stackrel{2}{r}}$ & $\stackrel{n}{\stackrel{n}{r}}$ & $\underset{\infty}{\stackrel{\infty}{\sim}}$ & 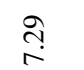 & $\underset{\infty}{\mathbb{\infty}}$ & 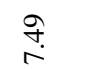 \\
\hline छ & $\underset{\stackrel{\alpha}{a}}{\stackrel{\sigma}{a}}$ & 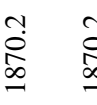 & $\underset{\substack{2 \\
\infty}}{\infty}$ & 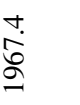 & $\stackrel{\infty}{\stackrel{\infty}{\grave{~}}}$ & 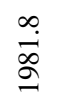 & 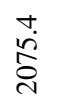 & $\stackrel{\approx}{\Omega}$ & ڤิ) & $\begin{array}{l}0 \\
\stackrel{+}{2} \\
\stackrel{n}{N}\end{array}$ & 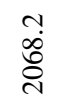 & $\begin{array}{l}\infty \\
\stackrel{0}{0} \\
\stackrel{0}{0}\end{array}$ \\
\hline 实言 & 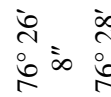 & 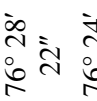 & 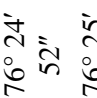 & $\begin{array}{l}i \vec{i} \\
\text { ì } \\
\text { io }\end{array}$ & & $\begin{array}{l}\dot{i} \\
\dot{v}= \\
\text { io }\end{array}$ & $\begin{array}{l}\dot{y} \\
\dot{m} \\
\dot{0}\end{array}$ & & & & $\begin{array}{l}\dot{m} \\
\dot{m} \\
\dot{0}\end{array}$ & $\begin{array}{l}\dot{m} \\
\dot{m} \\
\dot{0}\end{array}$ \\
\hline 1. & 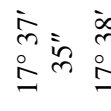 & 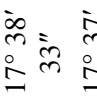 & 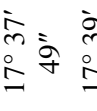 & 啇 & $\stackrel{+}{\circ}$ & $\begin{array}{l}\dot{+}= \\
\stackrel{+}{\circ} \\
\stackrel{1}{I}\end{array}$ & 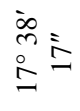 & $\begin{array}{l}\dot{2} \\
\dot{2} \\
\stackrel{0}{1}\end{array}$ & 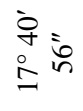 & $\begin{array}{l}\dot{\vec{\gamma}} \\
\stackrel{1}{\Sigma}\end{array}$ & $\begin{array}{l}\dot{\bar{m}}= \\
\stackrel{2}{\underline{y}}=\end{array}$ & 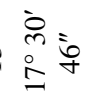 \\
\hline 胥 & 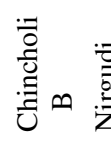 & 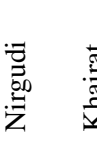 & 节 & 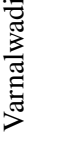 & $\frac{\dot{0}}{\grave{\alpha}}$ & $\begin{array}{l}\tilde{0} \\
\overline{0} \\
\frac{0}{0} \\
\infty \\
\infty\end{array}$ & 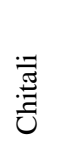 & 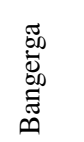 & 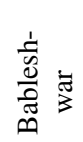 & 帚 & 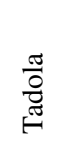 & 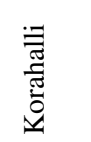 \\
\hline & $\vec{\sim}$ & ส & $\approx$ & $\stackrel{\sim}{\sim}$ & $\approx$ & i & $\hat{\sim}$ & $\stackrel{\sim}{\infty}$ & ते & \&్ల & $\bar{m}$ & $\tilde{m}$ \\
\hline
\end{tabular}


急

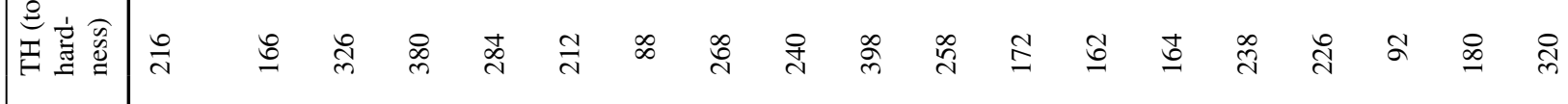

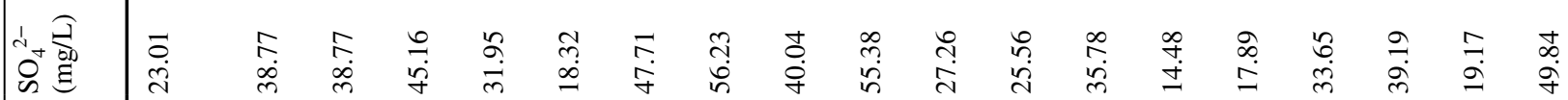

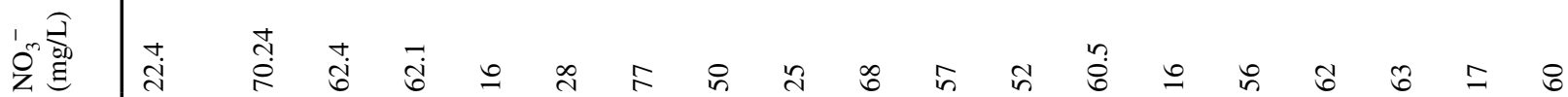

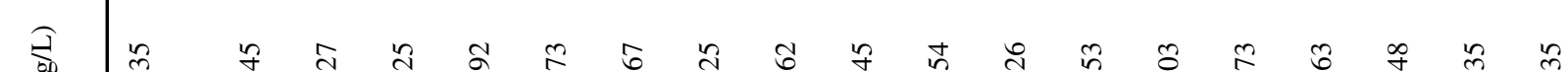

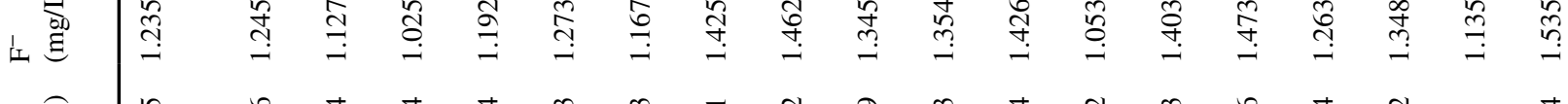

它望

两金

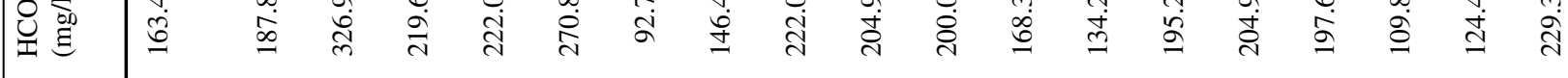

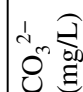

隹索

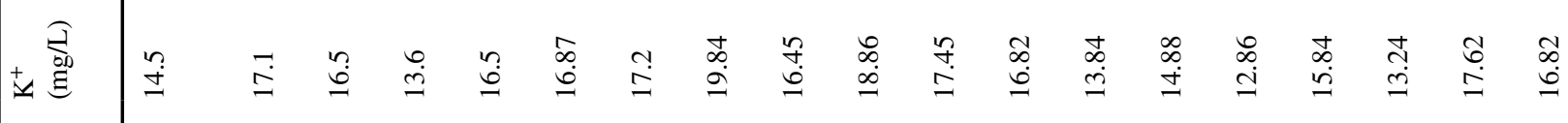

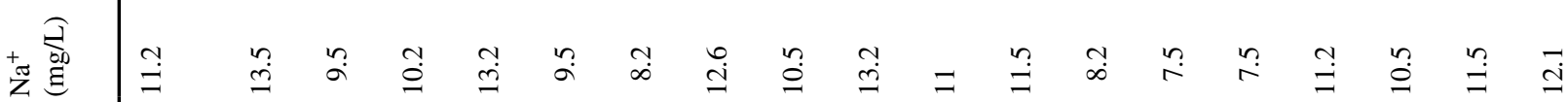

落

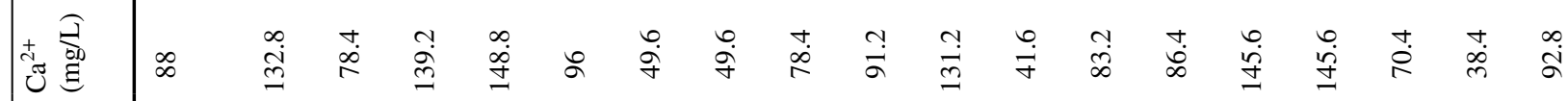

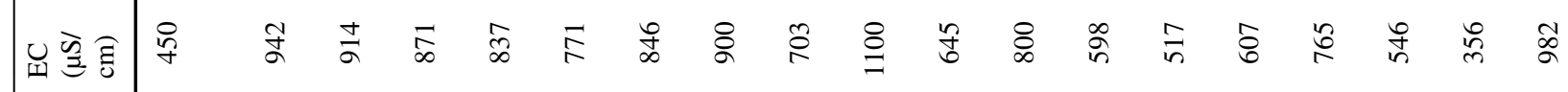

刍总

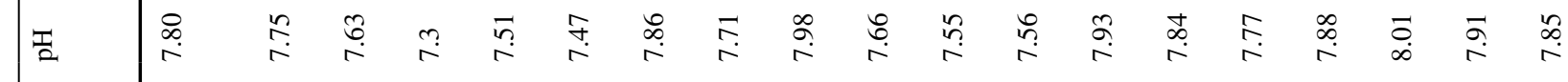

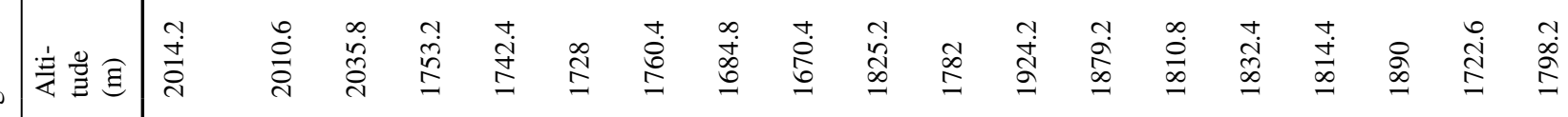

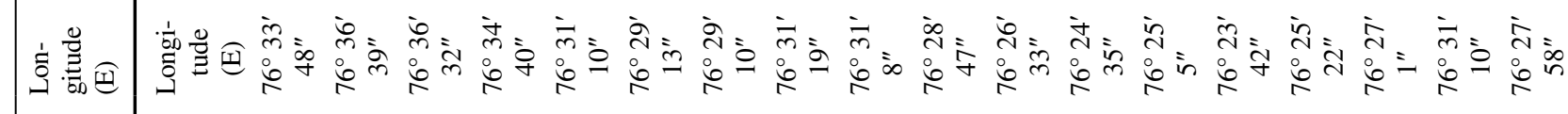

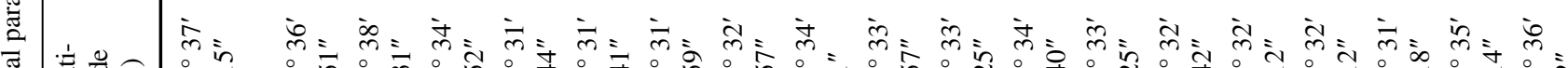

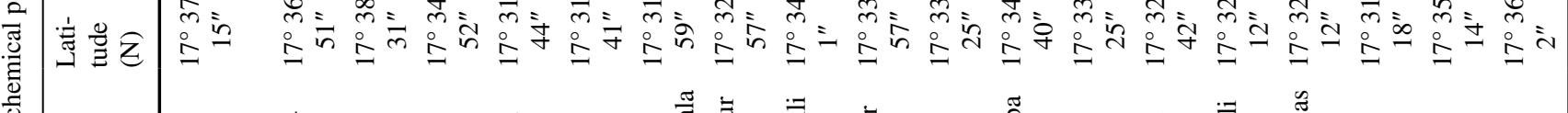

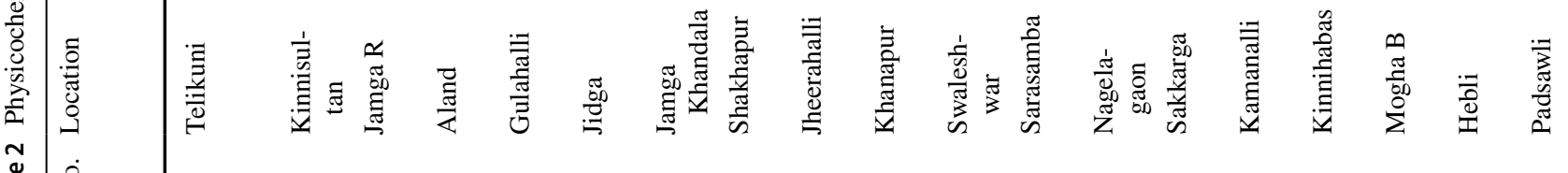
寧 


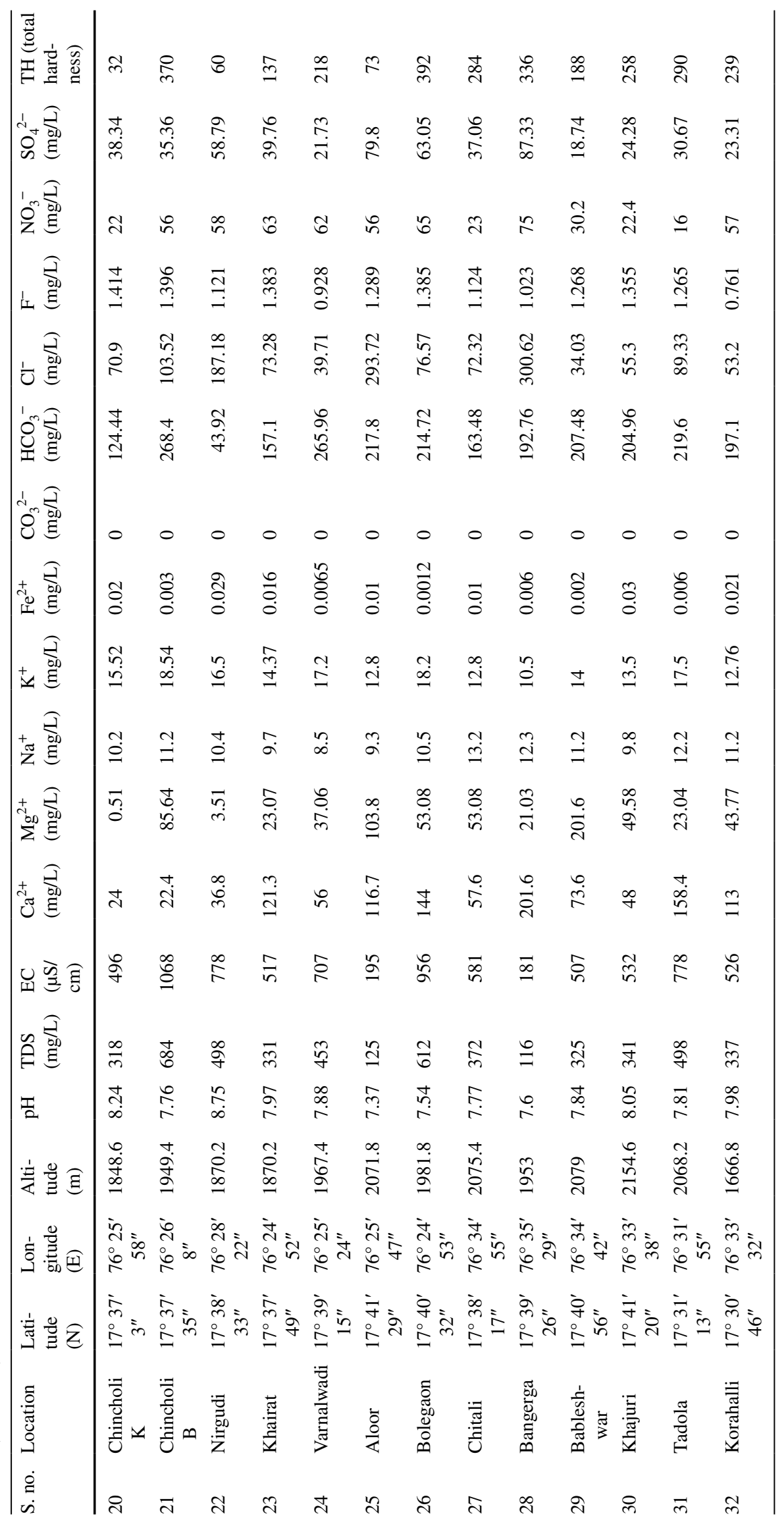


Fig. 2 Geospatial distribution of $\mathrm{pH}$ (pre-monsoon)

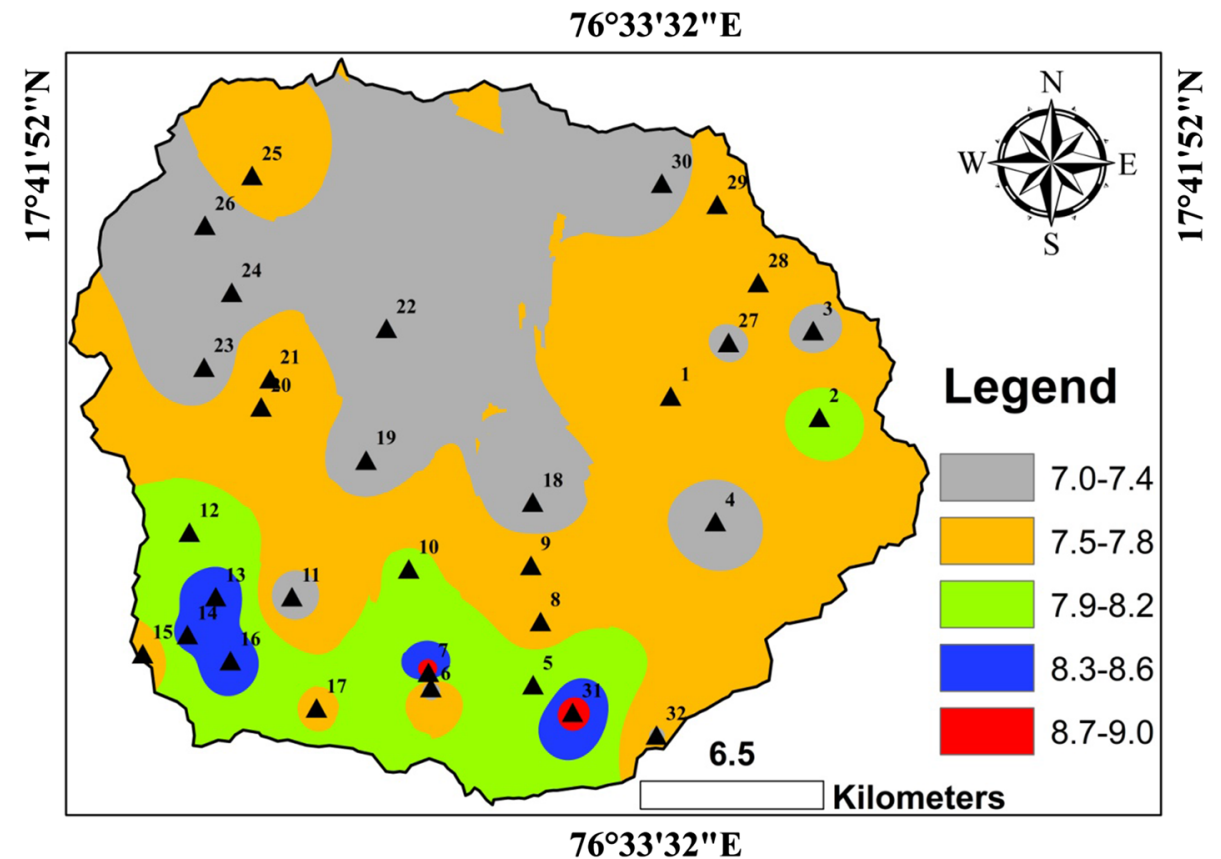

$76^{\circ} 33$ '32"E

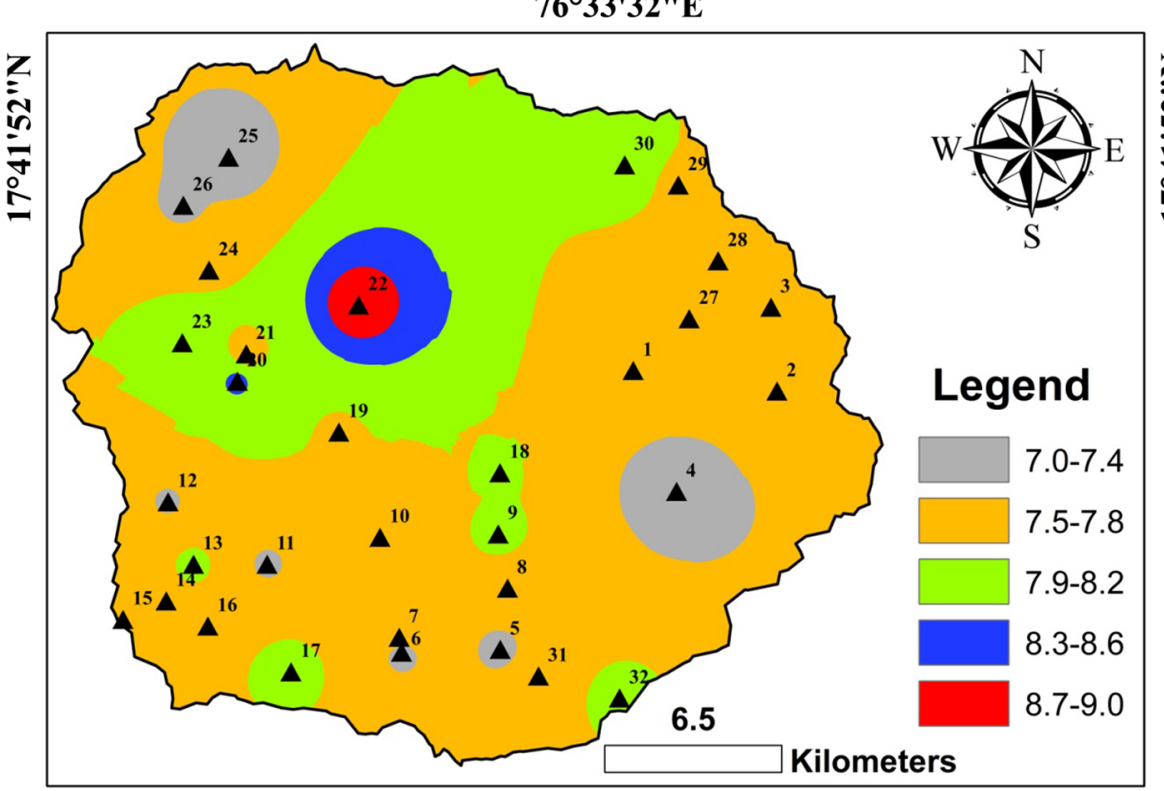

76 33 '32"E
Fig. 3 Geospatial distribution of $\mathrm{pH}$ (post-monsoon) the post-monsoon season, magnesium values showed variation from 1.01 to $201.6 \mathrm{mg} / \mathrm{L}$. Spatial distribution map of both monsoon seasons is depicted in Figs. 10 and 11. During pre-monsoon season, $31.25 \%$ of groundwater sample of the study area has magnesium concentration above the permissible limit, whereas $50 \%$ of the samples were exceeded during post-monsoon season.

\section{Sodium and potassium}

The concentration of sodium of pre-monsoon seasons was found in the range from 7.89 to $13.76 \mathrm{mg} / \mathrm{L}$, whereas it was in a range from 7.50 to $13.50 \mathrm{mg} / \mathrm{L}$ during post-monsoon season. According to the BIS (2012) guidelines, the maximum permissible limit is $200 \mathrm{mg} / \mathrm{L}$, and all the samples were in the allowable limit during both monsoon seasons. 
Fig. 4 Geospatial distribution of EC (pre-monsoon)

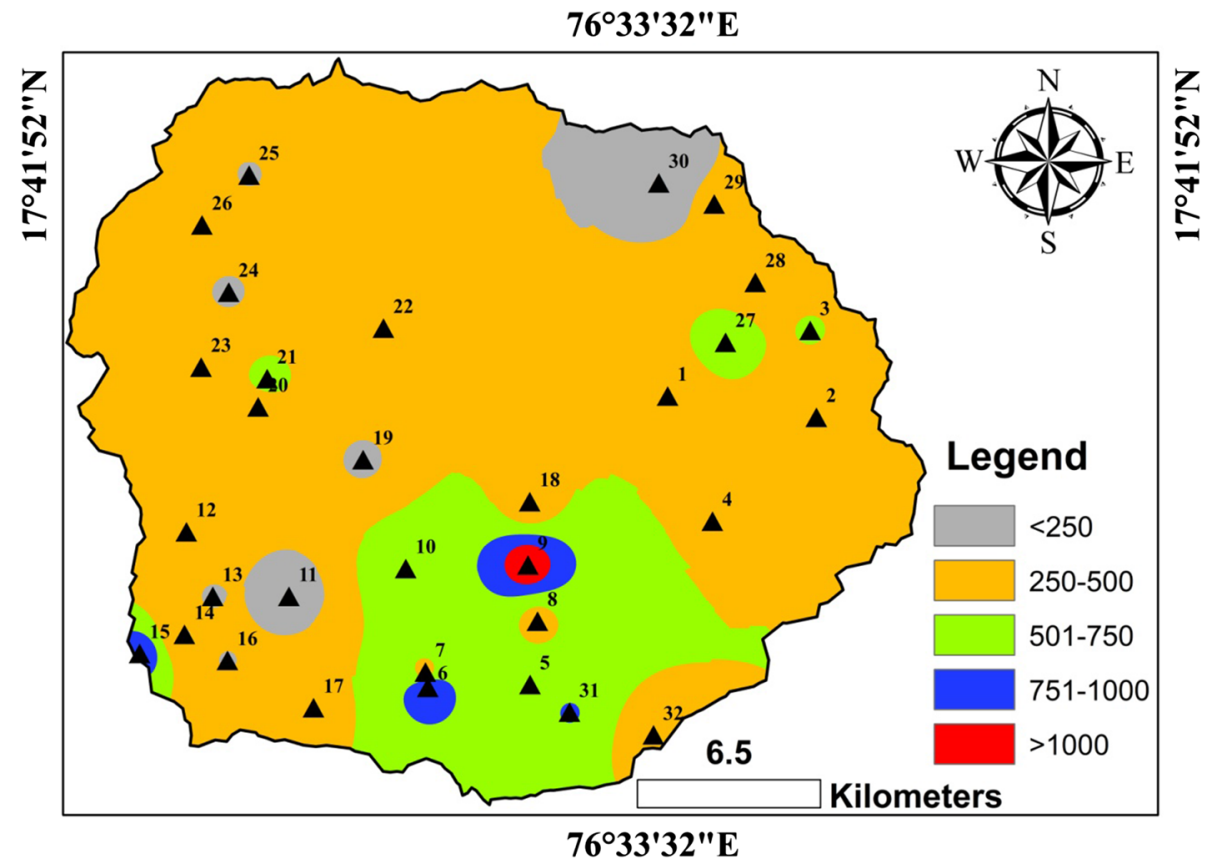

$76^{\circ} 3332^{\prime \prime E}$

Fig. 5 Geospatial distribution of EC (post-monsoon)

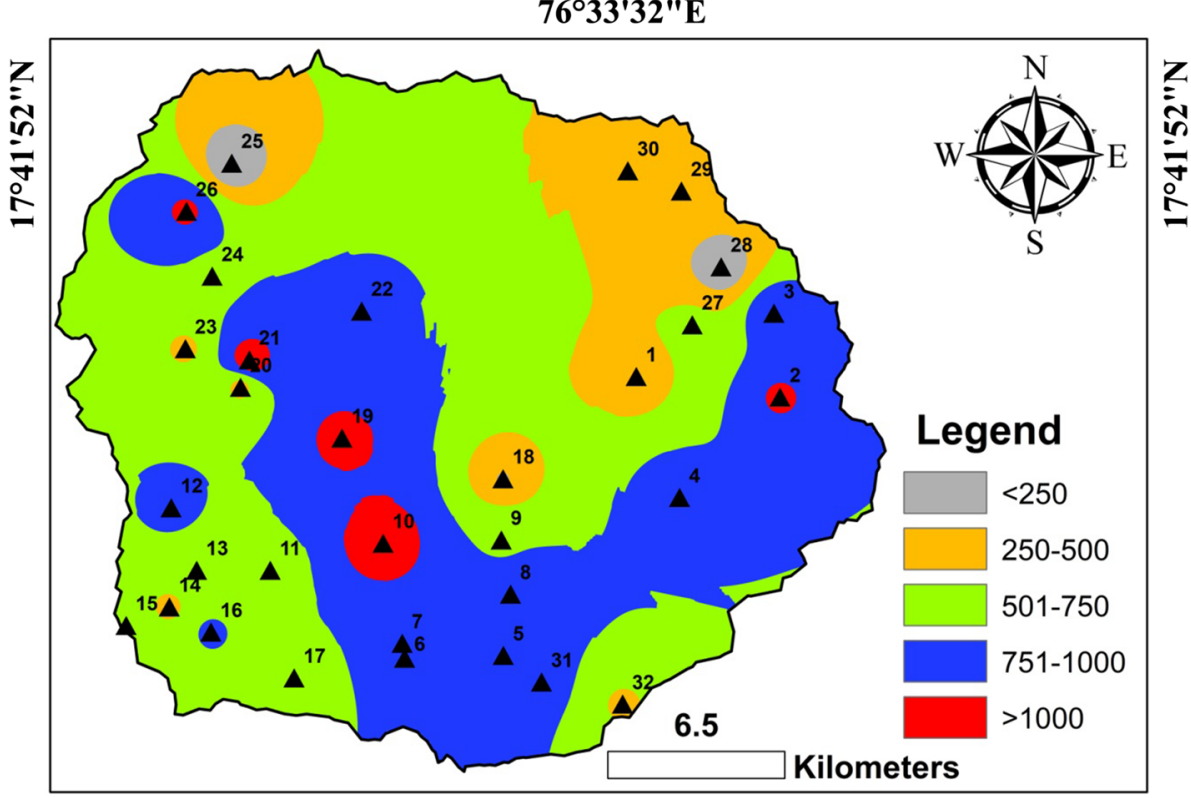

$7^{\circ} 33$ '32"E
Gceospatial map of both monsoon seasons is shown in Figs. 12 and 13. A higher concentration of sodium in groundwater makes it unsuitable for domestic use and causes severe health problems such as hypertension and kidney disorders in the human body (Adimalla and Venkatayogi 2017). Potassium concentration in groundwater ranges from 14.5 to $20.02 \mathrm{mg} / \mathrm{L}$ during pre-monsoon season, whereas it varies from 10.5 to $19.84 \mathrm{mg} / \mathrm{L}$ during post-monsoon season. All the groundwater samples were in the permissible limit. Geospatial distribution map for both the seasons is depicted in Figs. 14 and 15.

\section{Iron}

The water with no iron concentration is not considered as healthy because iron always plays a significant role in the nutrition of our body (Sharath et al. 2018). Iron value of pre-monsoon season was found in the range from 0.002 
Fig. 6 Geospatial distribution of TDS (pre-monsoon)

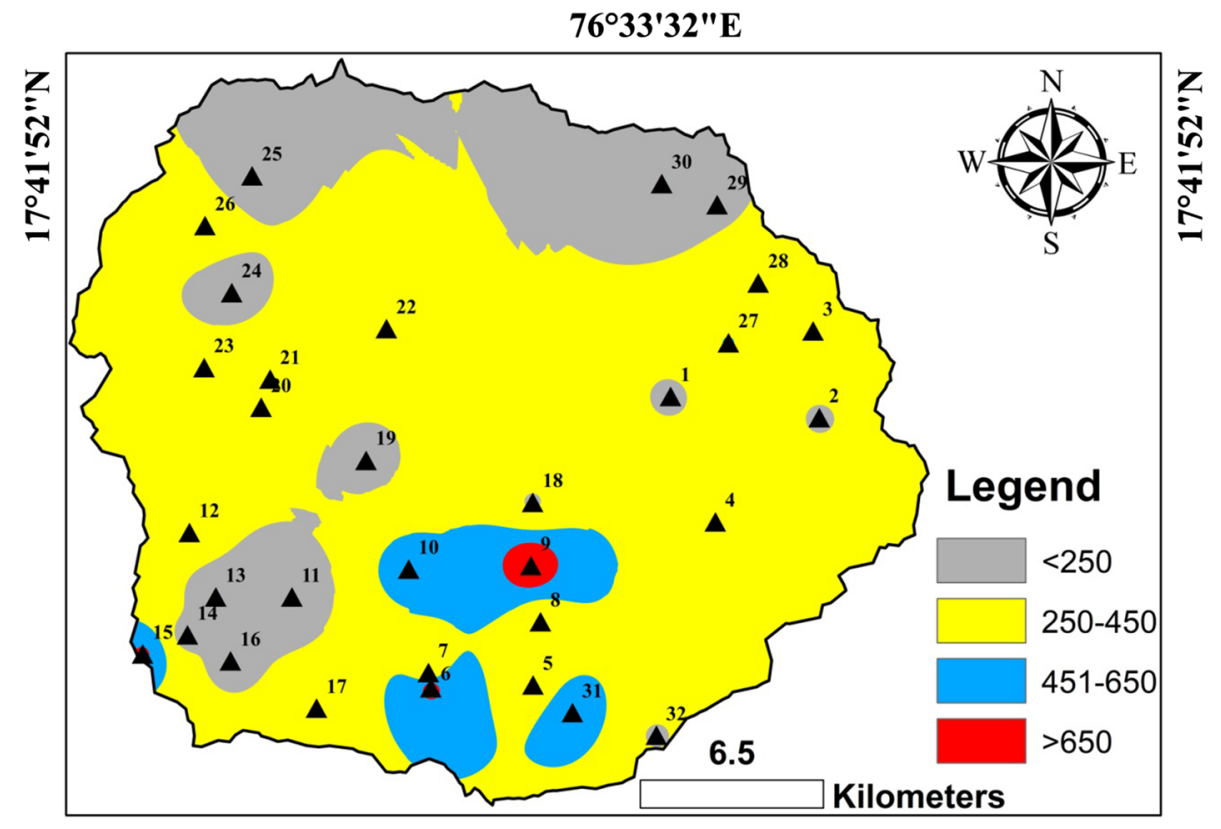

76'33'32"E

Fig. 7 Geospatial distribution of TDS (post-monsoon)

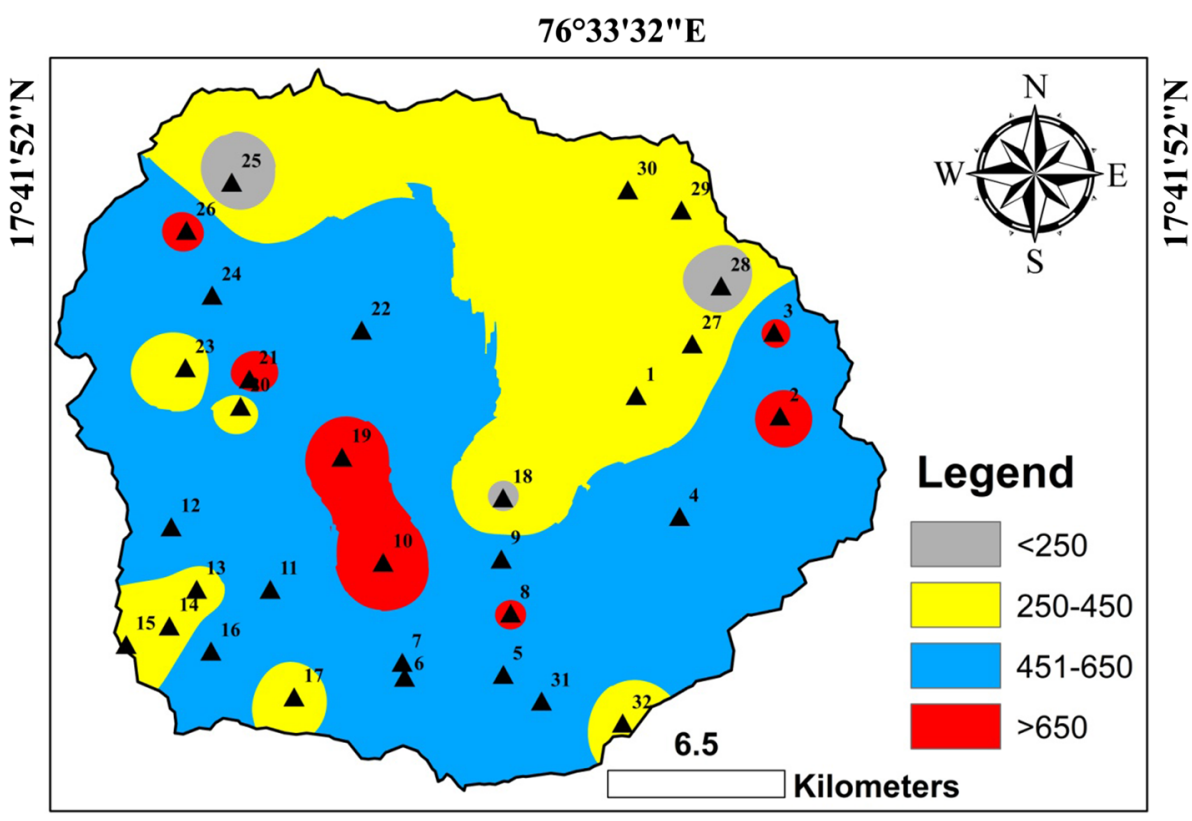

$7^{\circ} 33$ '32"E to $0.08 \mathrm{mg} / \mathrm{L}$, whereas the values were found varying from 0.001 to $0.08 \mathrm{mg} / \mathrm{L}$ during post-monsoon season. The acceptable permissible limit is $0.3 \mathrm{mg} / \mathrm{L}$ as per BIS standard (2012). None of the samples was exceeded to the allowable limit in both monsoon periods. The occurrence of iron strongly depends on the oxidation intensity of medium where it occurs (Hem 1985). Spatial distribution map of iron of both the seasons is shown in Figs. 16 and 17 for better understanding.

\section{Alkalinity (carbonate and bicarbonate)}

Carbonate in the groundwater of the study area varies from 0 to $122.4 \mathrm{mg} / \mathrm{L}$ during pre-monsoon, whereas it varies from 0 to $12 \mathrm{mg} / \mathrm{L}$ during post-monsoon season. The geospatial distribution map of both the seasons is shown in Figs. 18 and 19. Bicarbonate varies from 7.32 to $622.2 \mathrm{mg} / \mathrm{L}$, in the pre-monsoon, whereas it varies from 
Fig. 8 Geospatial distribution of calcium (pre-monsoon)

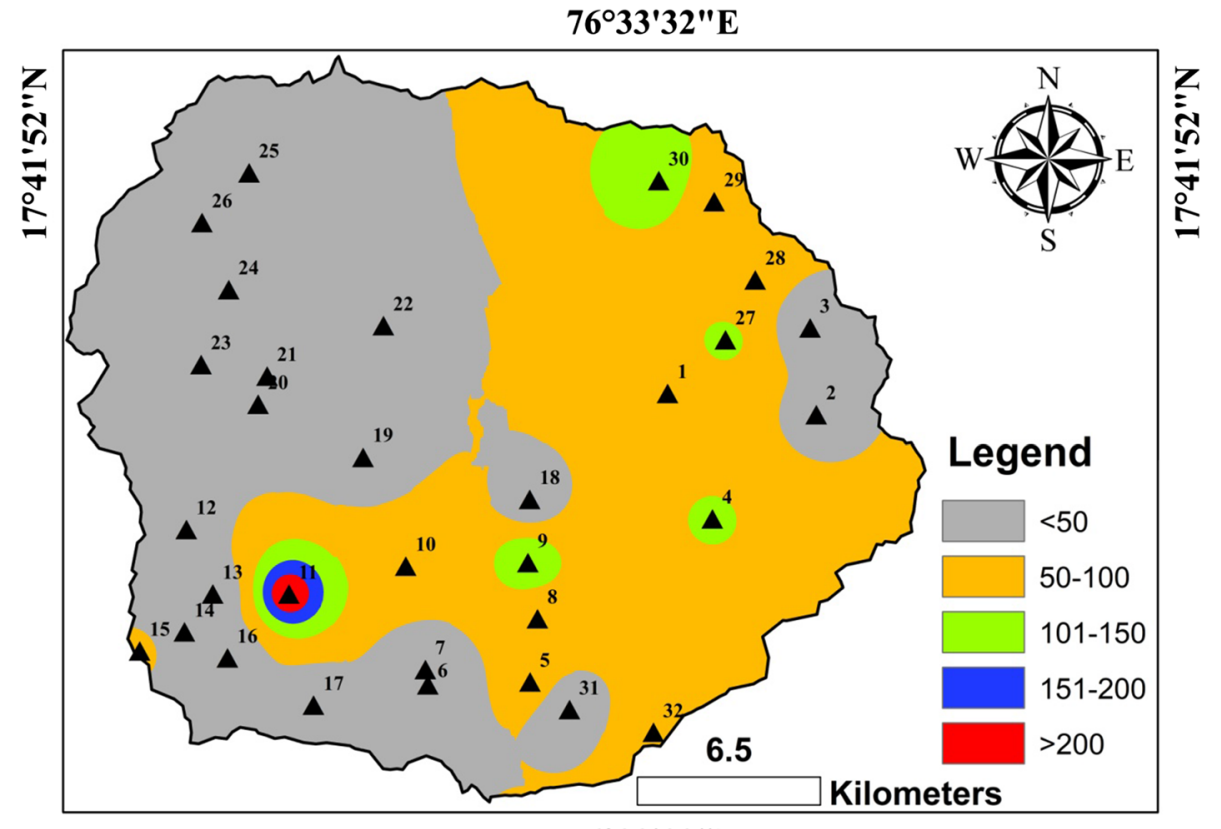

76'33'32"E

Fig. 9 Geospatial distribution of calcium (post-monsoon)

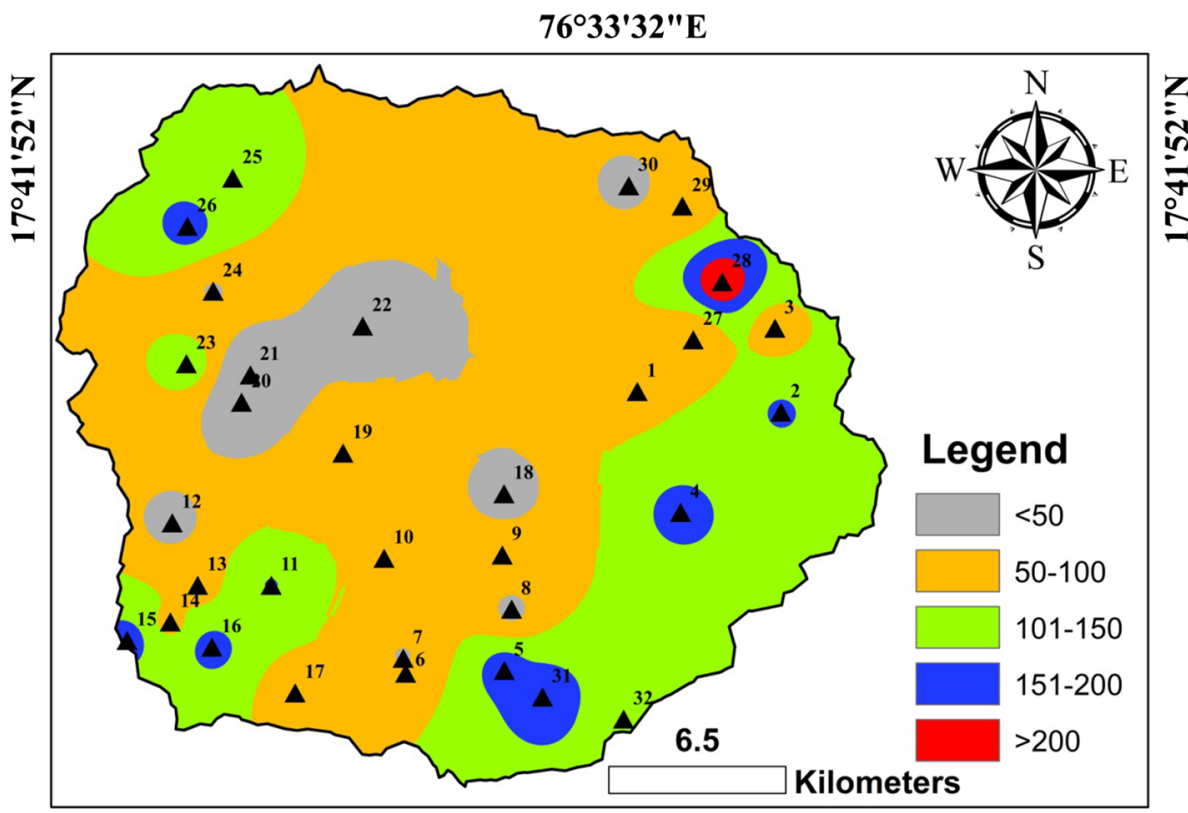

$7^{\circ} 33$ '32"E
43.92 to $326.96 \mathrm{mg} / \mathrm{L}$ during post-monsoon. Spatial distribution map of bicarbonate concentrations in groundwater is shown in Figs. 20 and 21. All the carbonate value was in the permissible range, but $18.75 \%$ of groundwater sample of bicarbonate has higher concentration during premonsoon season, whereas $50 \%$ were above the allowable limit during post-monsoon season. Geogenic activity may be responsible for the higher concentrations of bicarbonate within the region.

\section{Chloride and fluoride}

The chloride values of pre-monsoon season were found in the range from 32.62 to $373.98 \mathrm{mg} / \mathrm{L}$. The permissible limit of chloride in potable water is $250 \mathrm{mg} / \mathrm{L}$ (BIS 2012) and only $6.25 \%$ of groundwater samples were exceeded the allowable limit during pre-monsoon season. In the postmonsoon season, it varies from 34.03 to $300.62 \mathrm{mg} / \mathrm{L}$ and $6.25 \%$ of the samples were above the concentration. Leaching of upper soil layers and dry climate may be responsible 
Fig. 10 Geospatial distribution of magnesium (pre-monsoon)

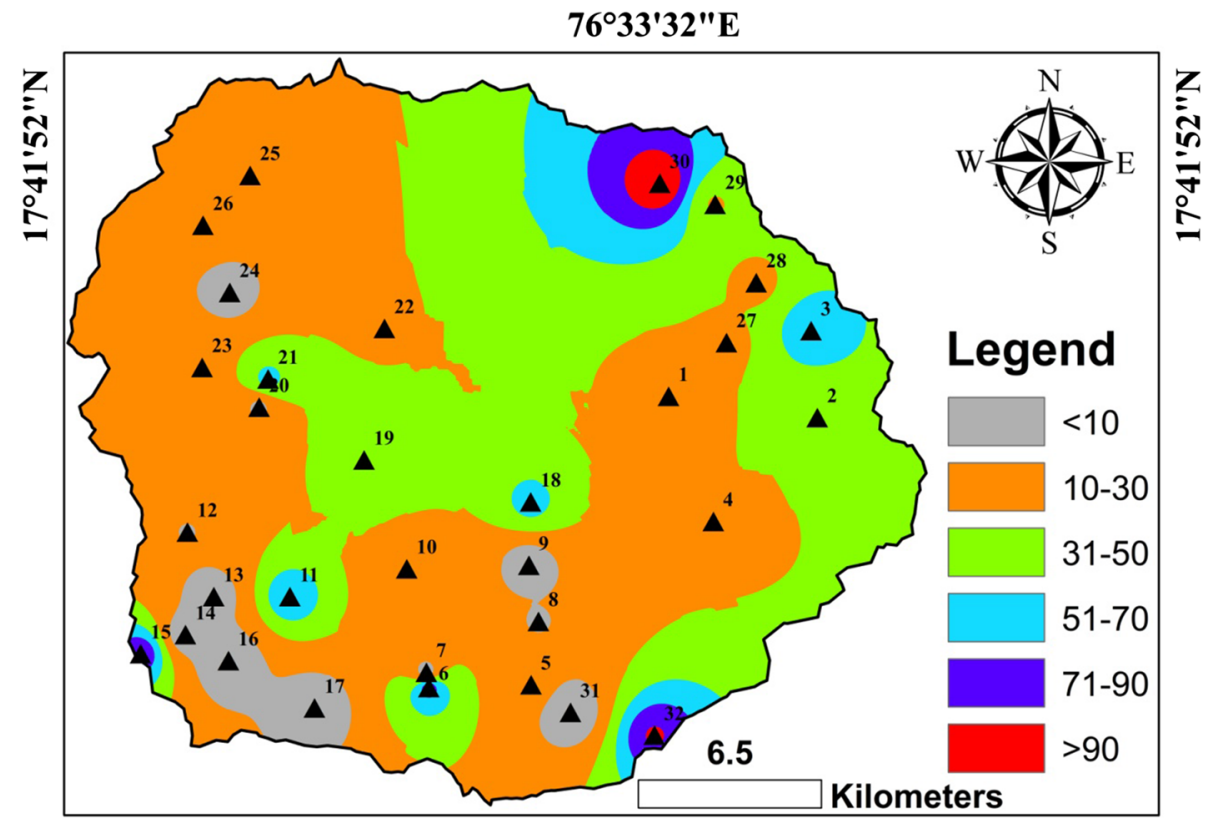

76'33'32"E

Fig. 11 Geospatial distribution of magnesium (post-monsoon)

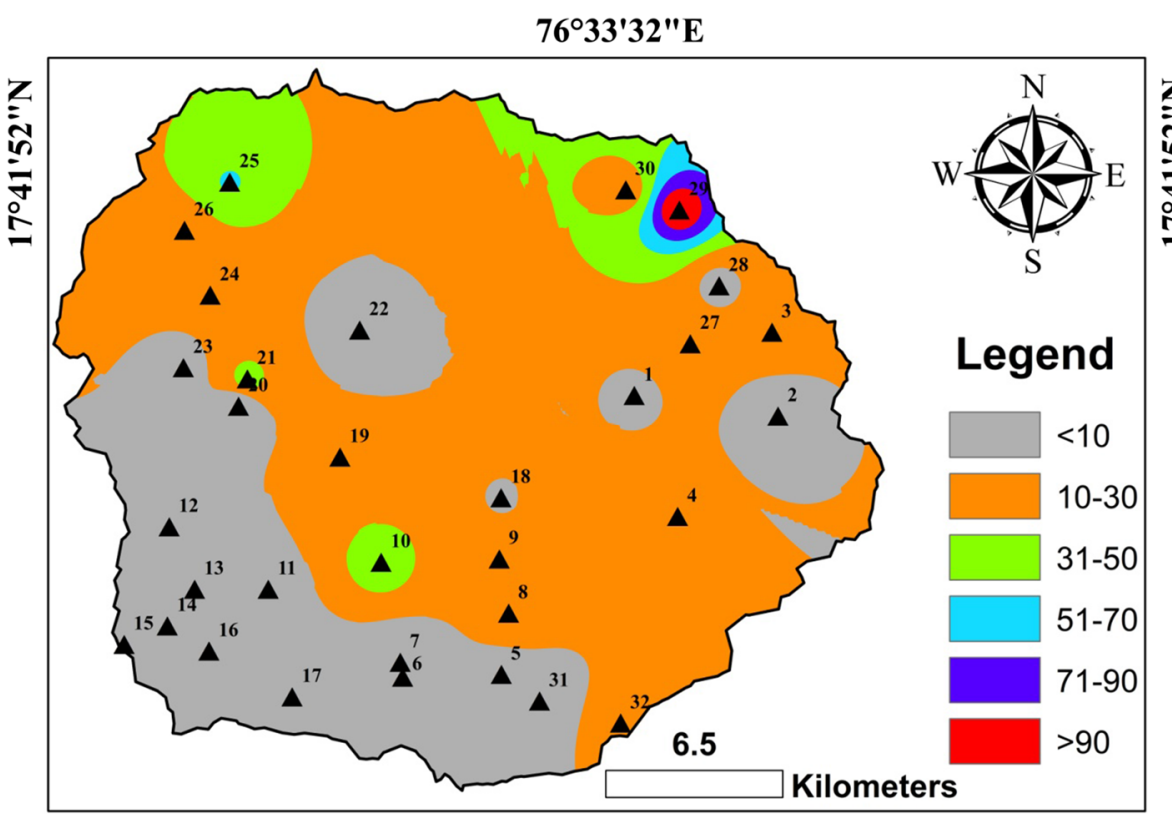

$7^{\circ} 33 ' 32^{\prime \prime} \mathrm{E}$ for the higher concentrations of chloride (Bhardwaj and Singh 2011). Geospatial mapping of chloride of both seasons is shown in Figs. 22 and 23.

The fluoride concentration in groundwater shows a range of 0.65 to $1.97 \mathrm{mg} / \mathrm{L}$. The highest value of fluoride was recorded in Nagelagaon $(1.97 \mathrm{mg} / \mathrm{L})$, whereas the lowest value was noted in Tadola village. In the pre-monsoon season, $78.13 \%$ of the groundwater samples of the region were above the desirable limit $(1.00 \mathrm{mg} / \mathrm{L})$, whereas $15.62 \%$ of the groundwater has more than $1.5 \mathrm{mg} / \mathrm{L}$ of fluoride which is the maximum permissible limit for drinking purposes as per BIS standard (2012). During postmonsoon season, the fluoride values varied from 0.76 to $1.54 \mathrm{mg} / \mathrm{L}$. The highest value of fluoride was recorded in Padsawli (1.54 mg/L), whereas the lowest value was in Korahalli village. Spatial distribution pattern of fluoride of both the seasons is depicted in Figs. 24 and 25. 90.63\% of the groundwater samples of the study area showed a higher concentration of fluoride above the desirable limit (1.00 mg/L). In contrast, only $3.12 \%$ of the groundwater 
Fig. 12 Geospatial distribution of sodium (pre-monsoon)

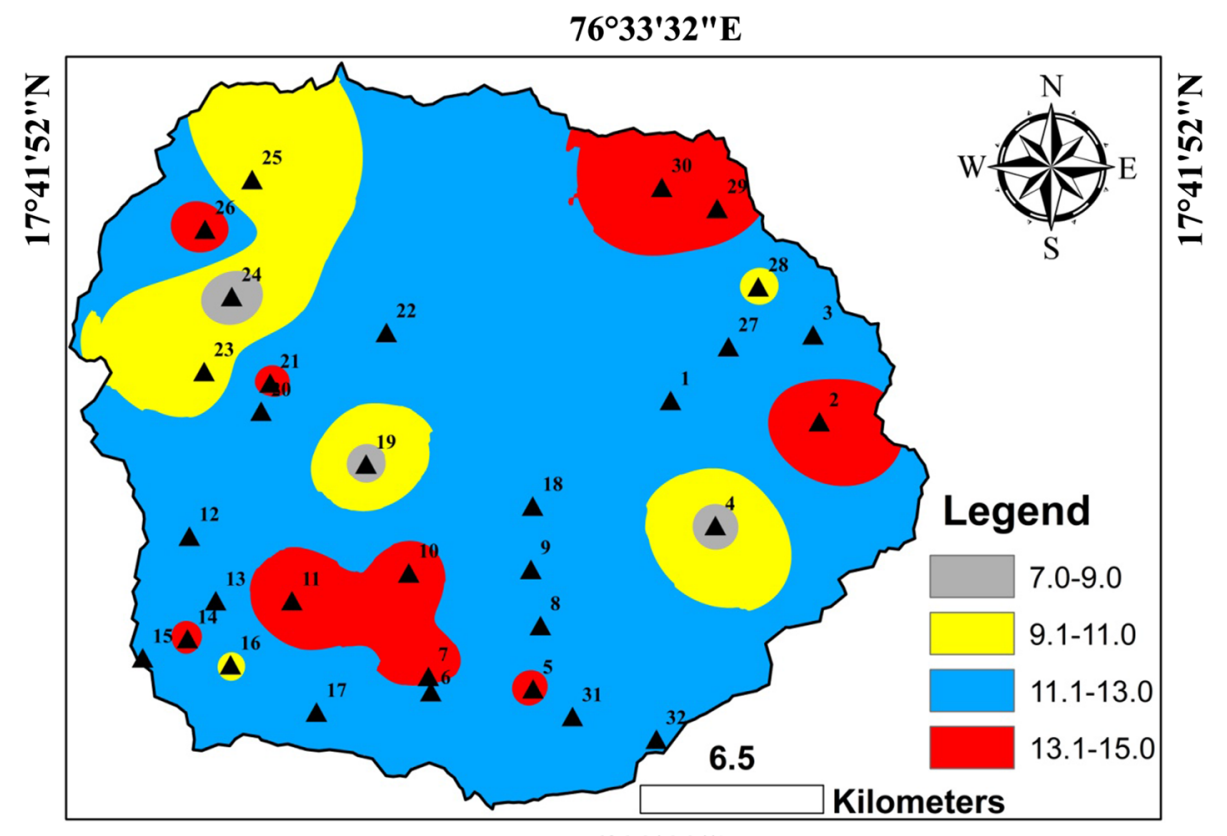

76³3'32"E

Fig. 13 Geospatial distribution of sodium (post-monsoon)

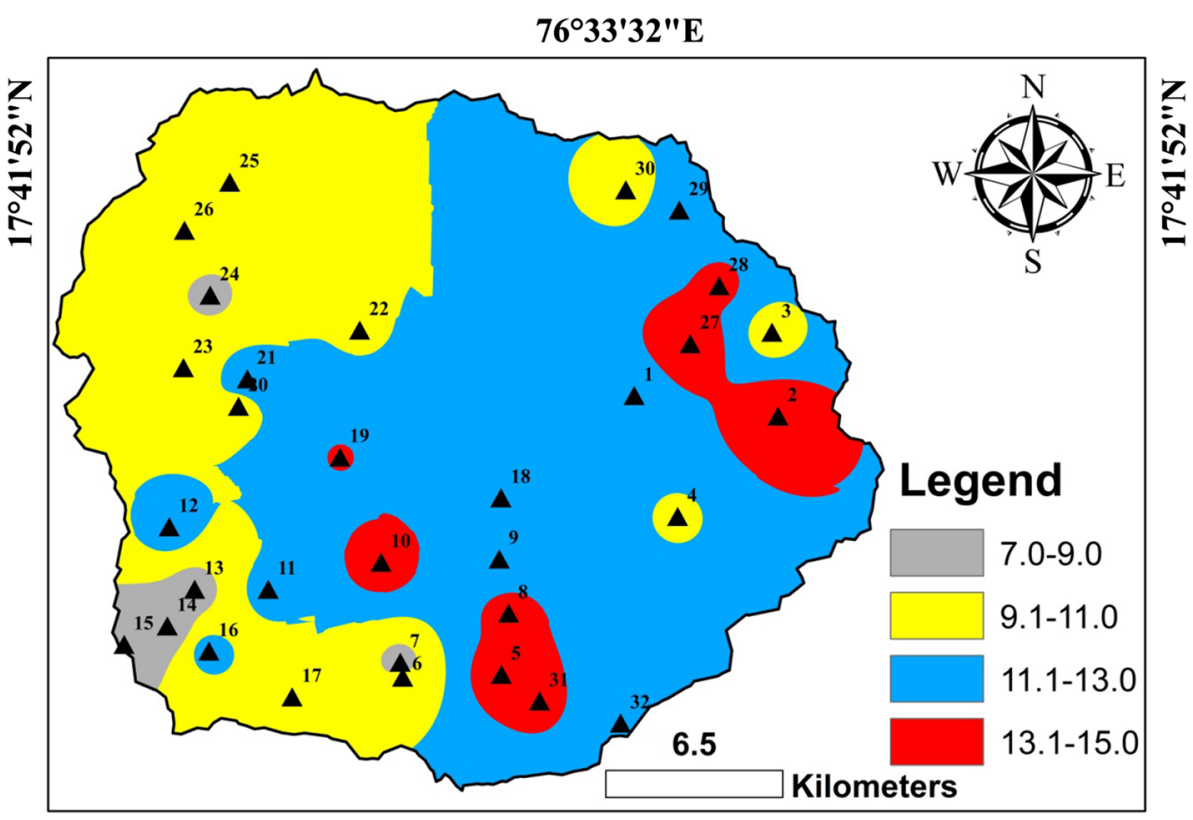

76 $^{\circ} 33^{\prime} 32^{\prime \prime} \mathrm{E}$ was above the maximum permissible $(1.5 \mathrm{mg} / \mathrm{L})$ limit of fluoride for drinking purposes. The sources of fluoride in the groundwater of the study region is mainly coming from the geological occurrence. The deep circulation of fluoride-rich groundwater between the lateralised basalts could be responsible for the event of fluoride in both the shallow and deeper aquifers (Raymond and Uday 2011). Excess fluoride concentration in groundwater can cause dental and skeletal fluorosis.

\section{Nitrate and sulphate}

Nitrate varies from 12 to $96 \mathrm{mg} / \mathrm{L}$ in pre-monsoon, whereas it ranged from 16 to $77 \mathrm{mg} / \mathrm{L}$ during post-monsoon. It has been noticed that $21.87 \%$ of the groundwater sample contains excess nitrate during pre-monsoon season, whereas $65.62 \%$ of the samples were above the permissible limit $(>45 \mathrm{mg} / \mathrm{L}$ ) in the study area, which is not suitable for drinking purpose. Geospatial distribution map has been prepared 
Fig. 14 Geospatial distribution of potassium (pre-monsoon)

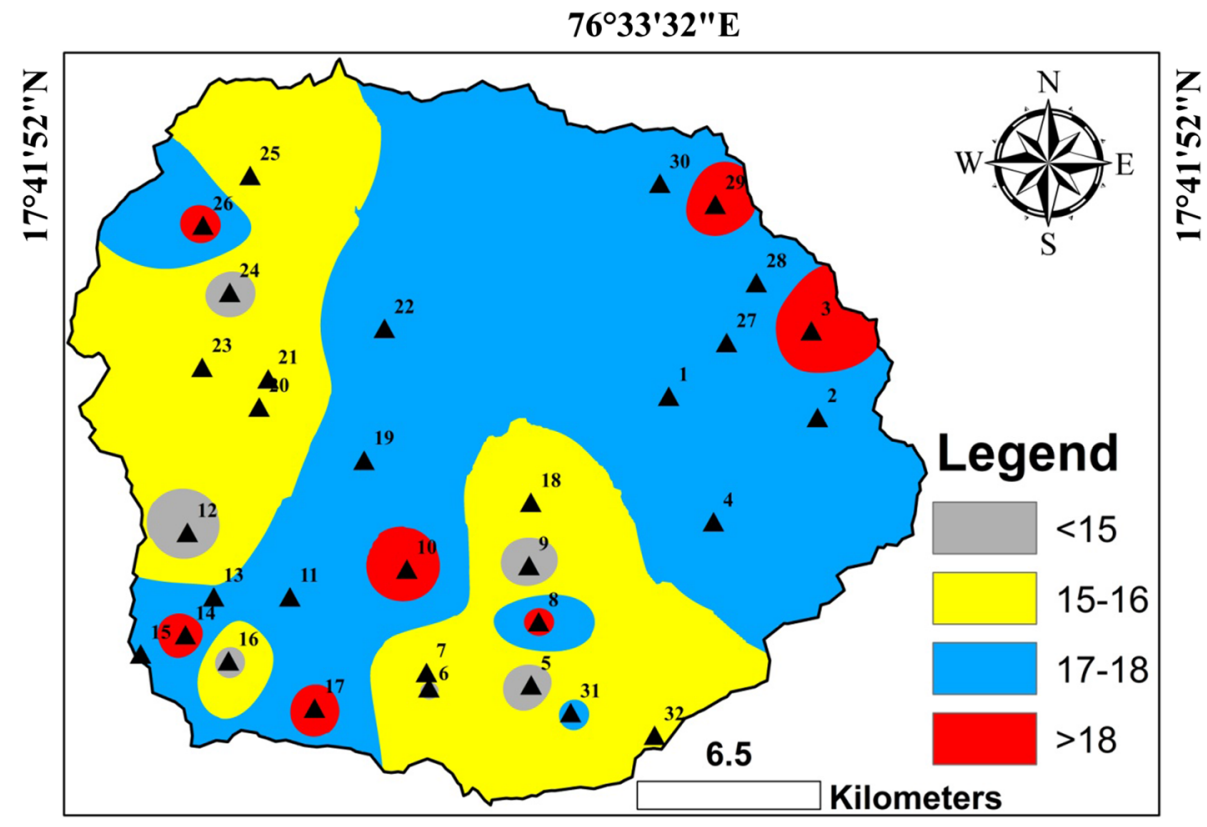

76³3'32"E

Fig. 15 Geospatial distribution of potassium (post-monsoon)

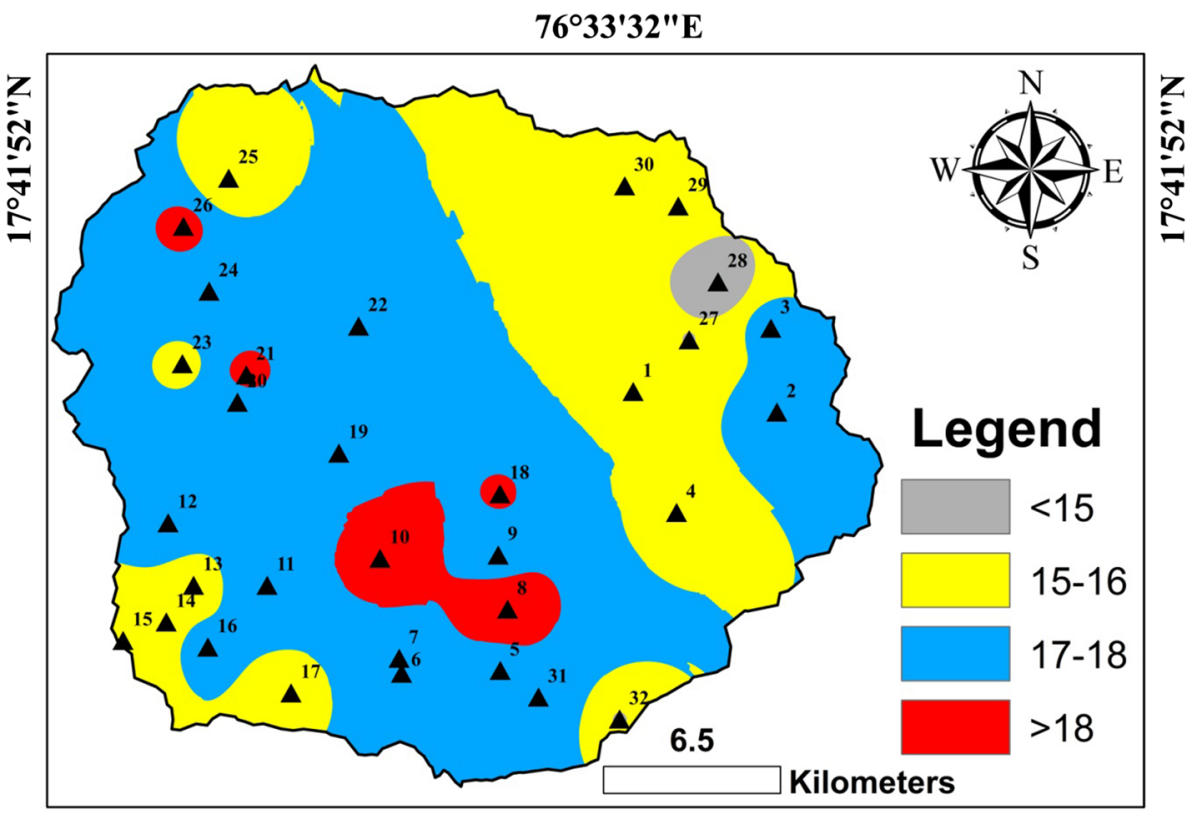

76³3'32"E for both the monsoon periods for the better understanding of excess nitrate within the region, and it is depicted in Figs. 26 and 27. A higher concentration of nitrate generally occur due to the inappropriate well structure, excessive use of chemical fertiliser or improper disposal of human, and animal waste and the higher concentration of nitrate in groundwater can lead to cancer (Dissanayake et al. 1987).

Sulphide is derived from the reduction of sulphate compounds, dissolved under low-oxygen condition when anaerobic bacteria are present (Lehr et al. 1980). The sulphate values of pre-monsoon seasons were found in the range from 7.2 to $128.65 \mathrm{mg} / \mathrm{L}$, whereas, during the post-monsoon season, it varies from 14.48 to $87.33 \mathrm{mg} / \mathrm{L}$. According to the BIS standard (2012), the permissible limit of sulphate in potable water is $200 \mathrm{mg} / \mathrm{L}$, and all the samples of the study area were in permissible limit during both the monsoon seasons. Spatial distribution map of sulphate of both seasons is shown in Figs. 28 and 29. 
Fig. 16 Geospatial distribution of iron (pre-monsoon)

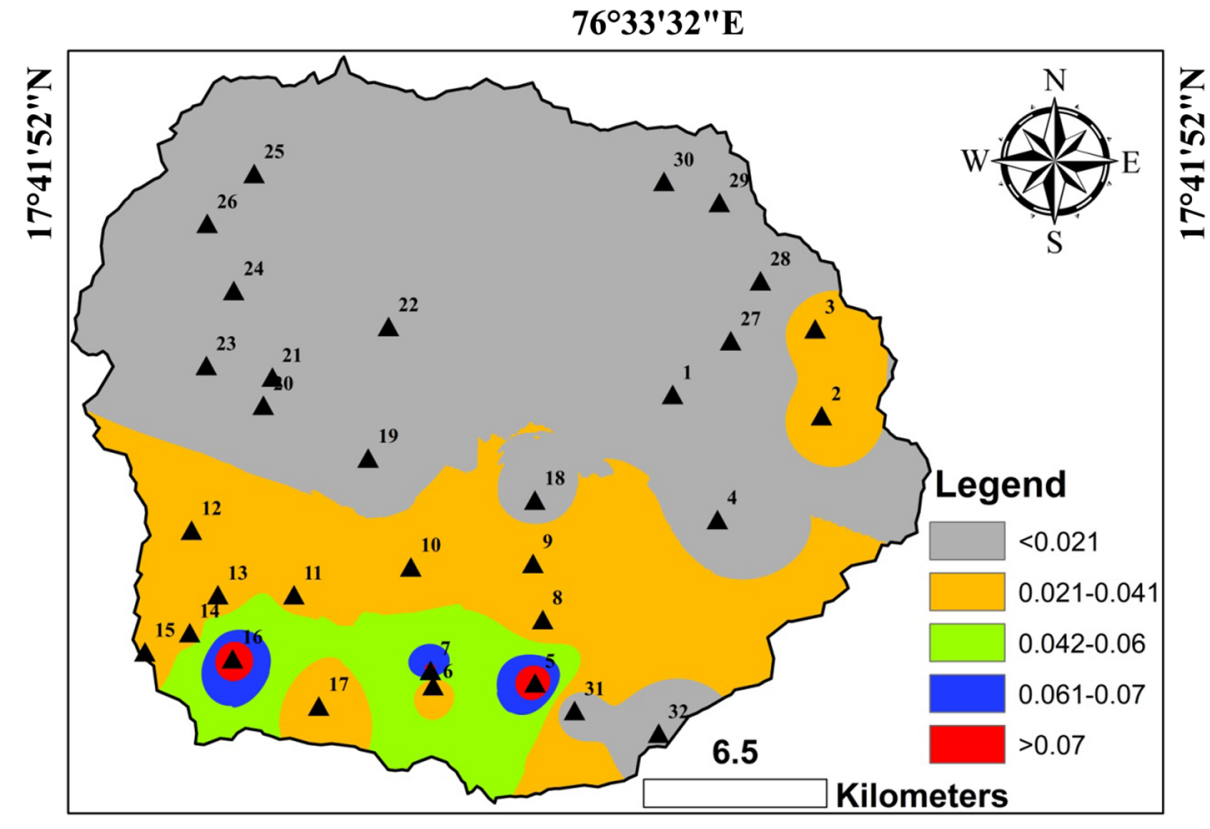

76'33'32"E

Fig. 17 Geospatial distribution of iron (post-monsoon)

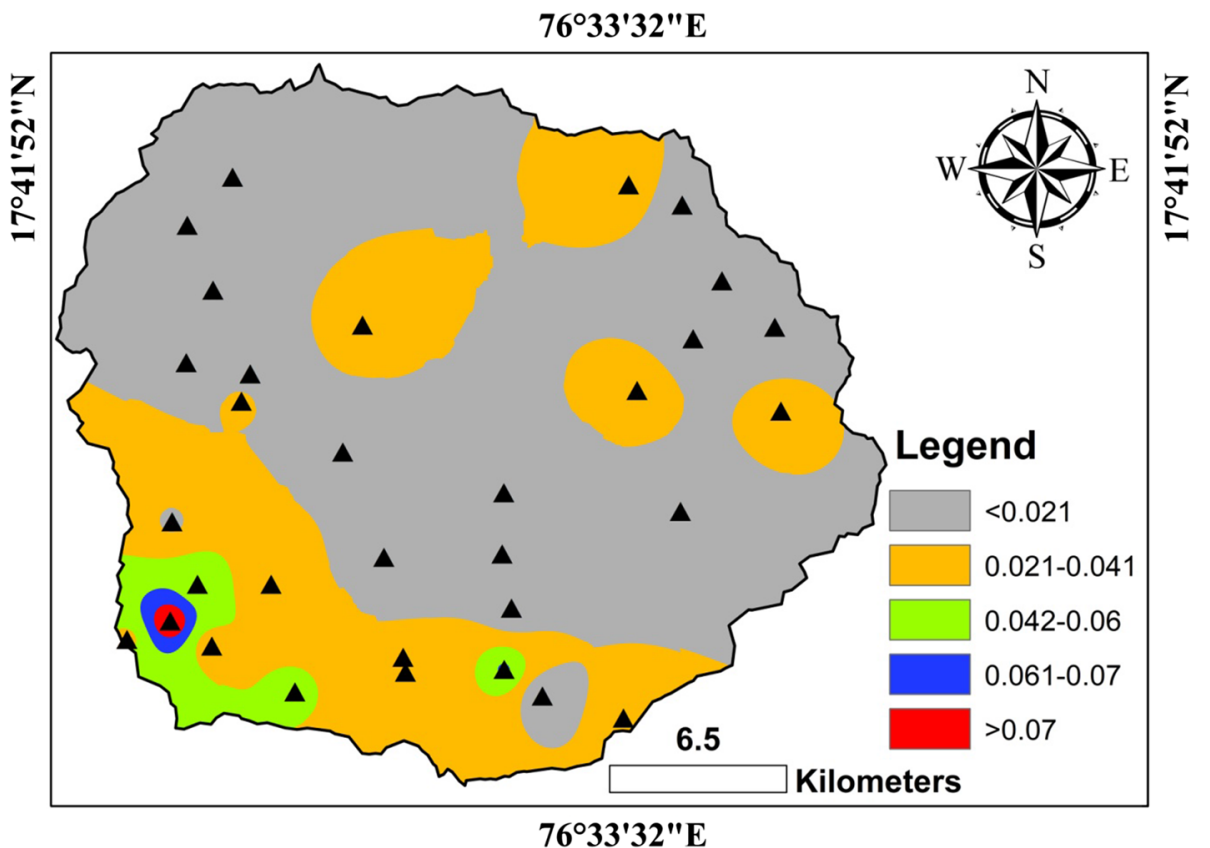

\section{Total hardness}

The hardness of water can be caused by the presence of multivalent metallic cations (Hem 1985). The hardness of water has a significant effect on $\mathrm{pH}$ and always substantial in the stability control of $\mathrm{pH}$. The hardness values of pre-monsoon season were found in the range from 20 to $704 \mathrm{mg} / \mathrm{L}$ and 32 to $398 \mathrm{mg} / \mathrm{L}$ during post-monsoon season. Geospatial distribution of hardness of both seasons is shown in Figs. 30 and 31. Nearly 56.25\% of the groundwater samples were exceeded the permissible limit (BIS 2012) during pre-monsoon season, whereas $62.5 \%$ of the samples were found to be above the allowable limit ( $>200 \mathrm{mg} / \mathrm{L}$ ) during post-monsoon season. The higher concentrations of the hardness may occur due to the weathering of calcium bearing minerals or disproportionate use of lime to the soil in agricultural regions.

Table 3 illustrates the percentage-wise drinking water suitability of study area. 
Fig. 18 Geospatial distribution of carbonate (pre-monsoon)

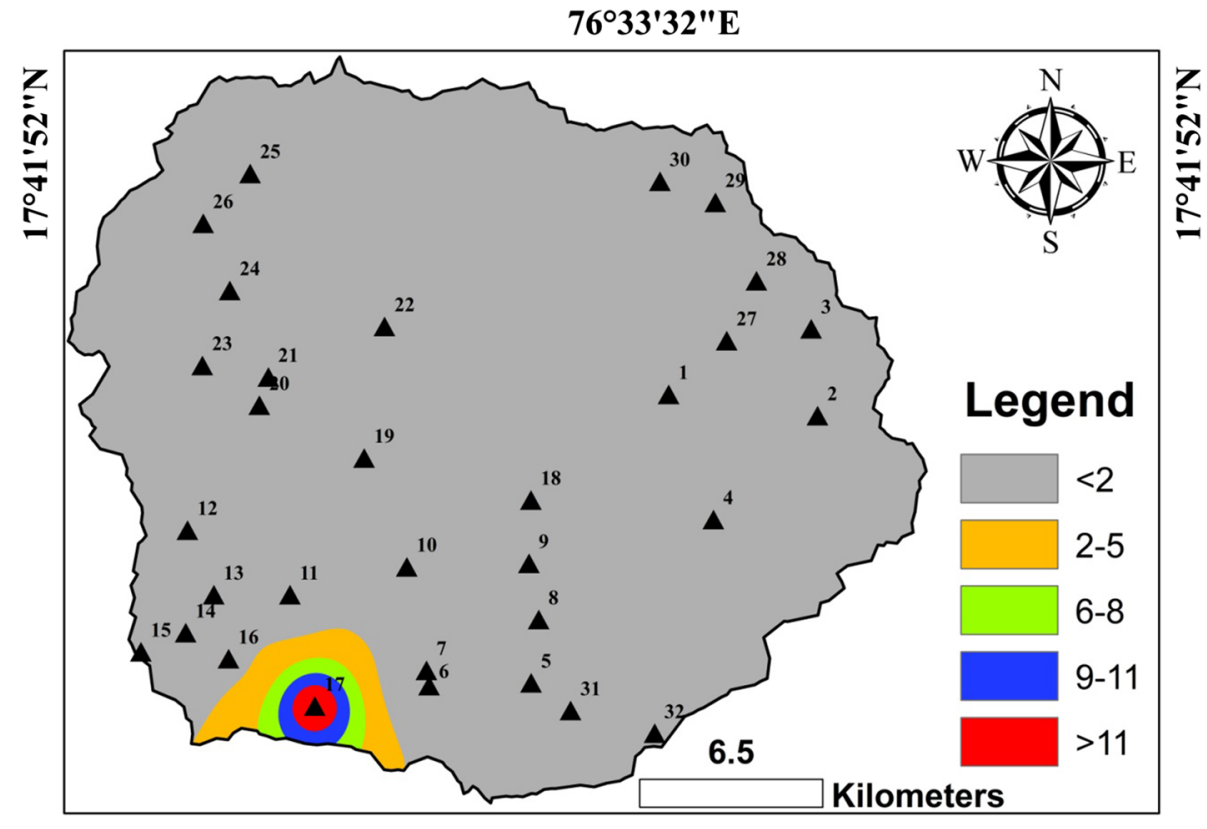

76³3'32"E

Fig. 19 Geospatial distribution of carbonate (post-monsoon)

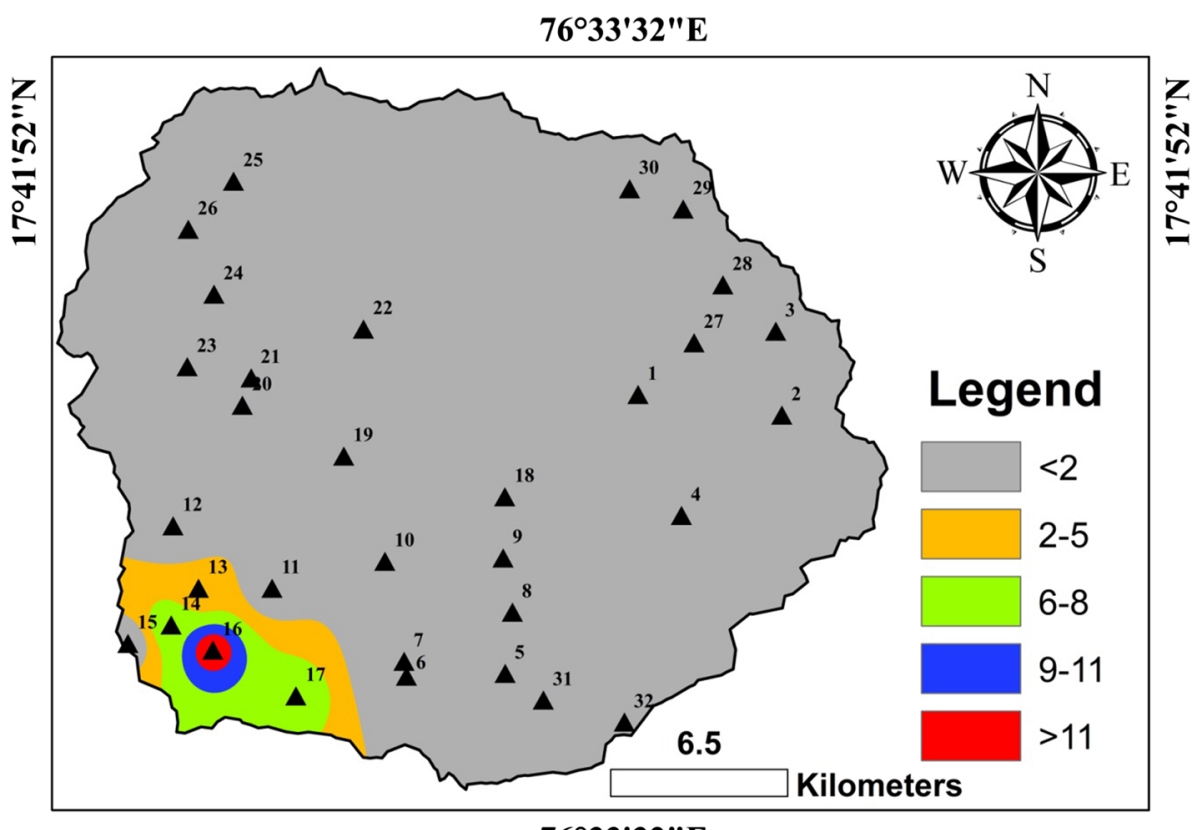

$7^{\circ} 33 ' 32^{\prime \prime} \mathrm{E}$

\section{Hydrochemical facies for groundwater (Chaddha's diagram)}

Hydrochemical facies of a particular region are always associated with the geology of that region, and the distribution of the facies is influenced by hydrogeological controls (Nagaraju et al. 2016). Hydrochemical facies can be well classified based on Chadha's diagram (Chadha 1999). Chadha's diagram explains the differences in milliequivalent percentage between alkaline earth's (calcium + magnesium) and alkali metals (sodium + potassium) expressed as percentage reacting value is plotted on the $\mathrm{X}$-axis. The difference in milliequivalent percentage between weak acidic anions (carbonate + bicarbonate) and strong acidic anions (chloride + sulphate) is plotted on the $\mathrm{Y}$-axis. The square or rectangular field depicts the overall character of the water (Nagaraju et al. 2016). The result of the chemical analyses data of all the samples was plotted on Chadha's diagram. The Chadha's plot of pre-monsoon season depicts that $56.25 \%$ of the groundwater samples 
Fig. 20 Geospatial distribution of bicarbonate (pre-monsoon)

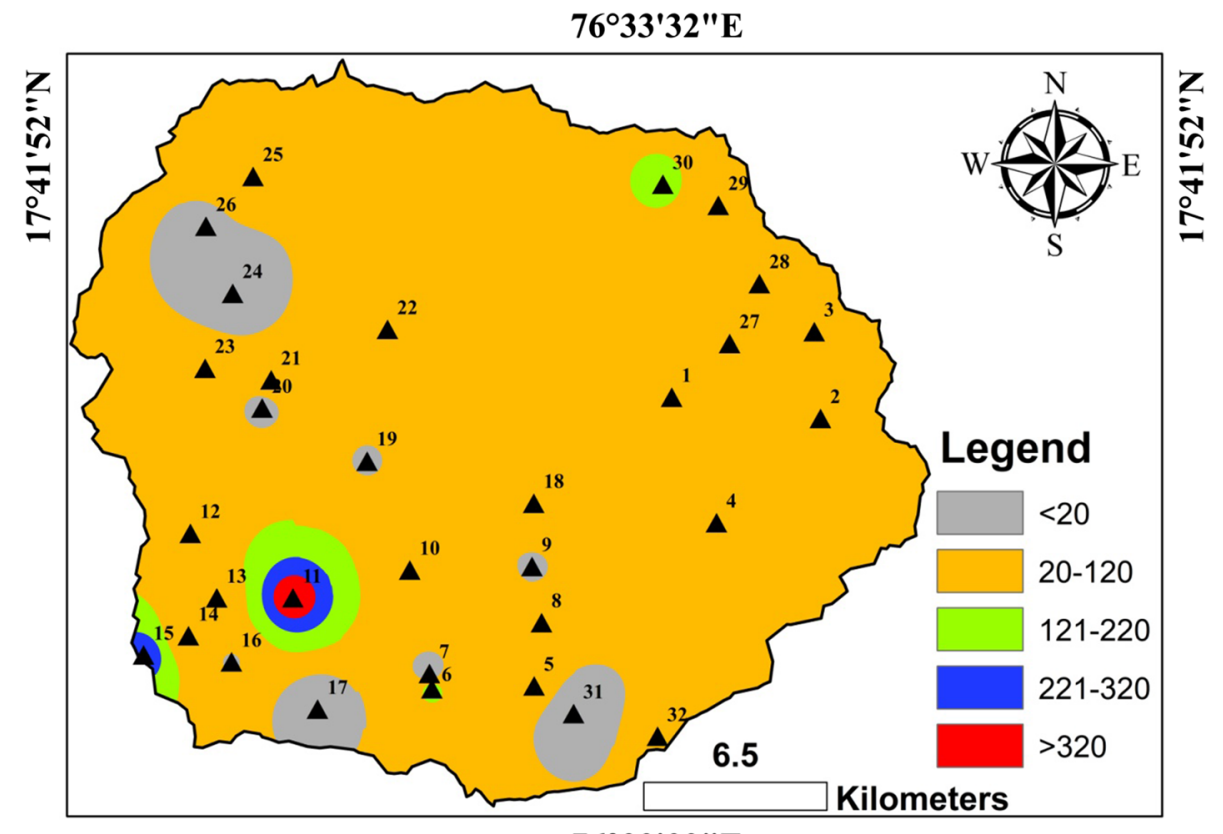

76'33'32"E

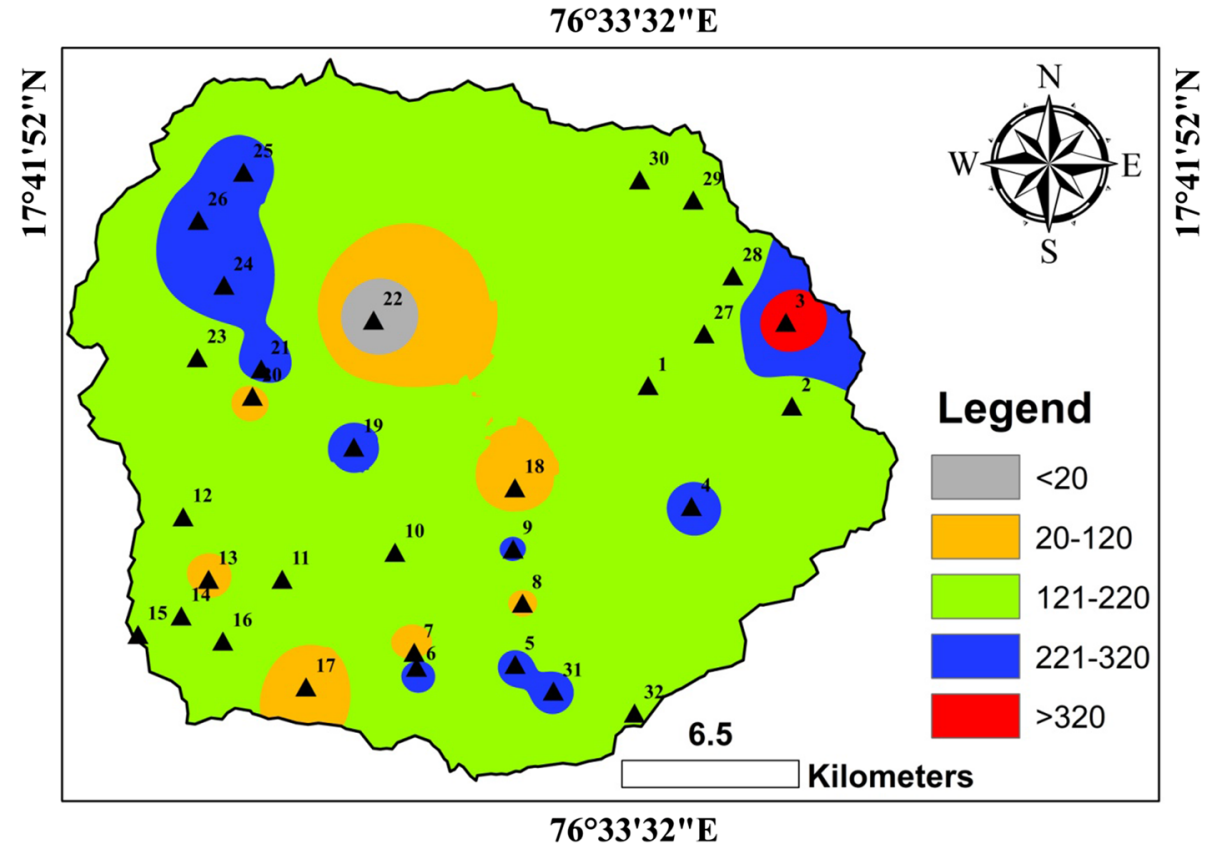

$7^{\circ} 33$ '32"E
Fig. 21 Geospatial distribution of bicarbonate (post-monsoon)
Gibbs's plot

fall under the subfield of $\mathrm{Ca}^{2+}-\mathrm{Mg}^{2+}-\mathrm{Cl}^{-}$water type with permanent hardness. The remaining $43.75 \%$ of samples fall under the subfield of $\mathrm{Ca}^{2+}-\mathrm{Mg}^{2+}-\mathrm{HCO}_{3}{ }^{-}$water type with temporary hardness (Fig. 32). In the post-monsoon season, the plot depicts that $50 \%$ samples fall under the field of $\mathrm{Ca}^{2+}-\mathrm{Mg}^{2+}-\mathrm{HCO}_{3}{ }^{-}$water type with temporary hardness, whereas the remaining 50\% samples belong to the subfield of $\mathrm{Ca}^{2+}-\mathrm{Mg}^{2+}-\mathrm{Cl}^{-}$water type with permanent hardness (Fig. 33).
Gibb's plot is used to characterise the quality of water to precipitation, evaporation/crystallisation and rock-water interaction. In 1970, Gibb's has established a relation water chemistry and aquifers lithology. In Gibb's plot, TDS on $\mathrm{y}$-axis, $\mathrm{Na}^{+}+\mathrm{K}^{+} / \mathrm{Na}^{+}+\mathrm{K}^{+}+\mathrm{Ca}^{2+}$ on $\mathrm{x}$-axis for cations and $\mathrm{Cl}^{-} / \mathrm{Cl}^{-}+\mathrm{HCO}_{3}{ }^{-}$on $\mathrm{x}$-axis for anion are plotted, respectively. It is useful to differentiate the interaction 
Fig. 22 Geospatial distribution of chloride (pre-monsoon)

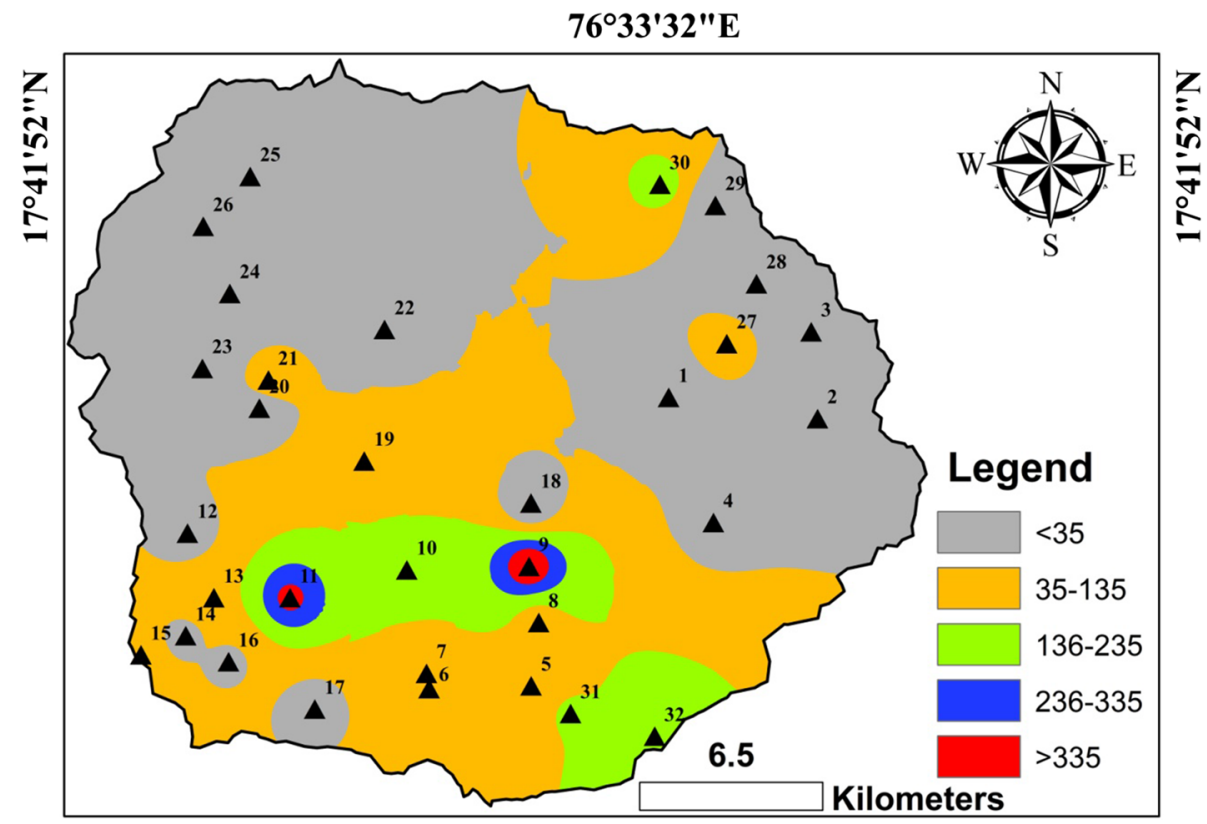

76³3'32"E

Fig. 23 Geospatial distribution of chloride (post-monsoon)

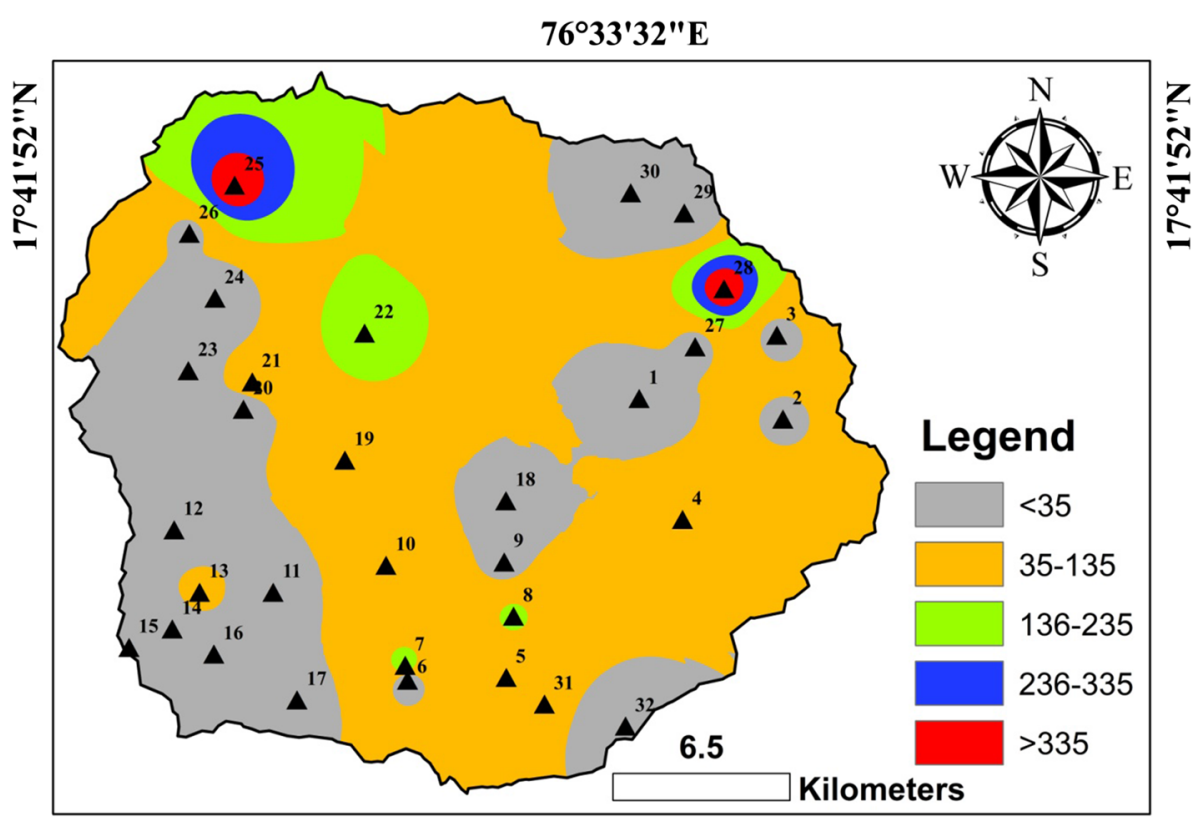

76³3'32"E of groundwater through precipitation or rock evaporation. Gibb's has recognised three kinds of fields which are known as precipitation, evaporation/crystallisation and rock-water interaction. Weathering dominated water would be having higher $\mathrm{Ca}^{2+}$ and $\mathrm{HCO}_{3}{ }^{-}$concentration, whereas evaporation/crystallisation-controlled water would be having a higher concentration of $\mathrm{Na}^{+}$and $\mathrm{Cl}^{-}$on Gibb's plot. Equations (1) and (2) describe Gibb's ratio for cation and anion, respectively.
(For Cation) Gibb's Ratio $=\frac{\mathrm{Na}+\mathrm{K}}{\mathrm{Na}+\mathrm{K}+\mathrm{Ca}}$

(For Anion) Gibb's Ratio $=\frac{\mathrm{Cl}}{\mathrm{Cl}+\mathrm{HCO}_{3}}$

where $\mathrm{Na}, \mathrm{K}, \mathrm{Ca}, \mathrm{Cl}$ and $\mathrm{HCO}_{3}$ are expressed in meq/l.

Gibb's plot of both the seasons of different cations and anions is shown in Figs. 34 and 35, respectively. Rock 
Fig. 24 Geospatial distribution of fluoride (pre-monsoon)

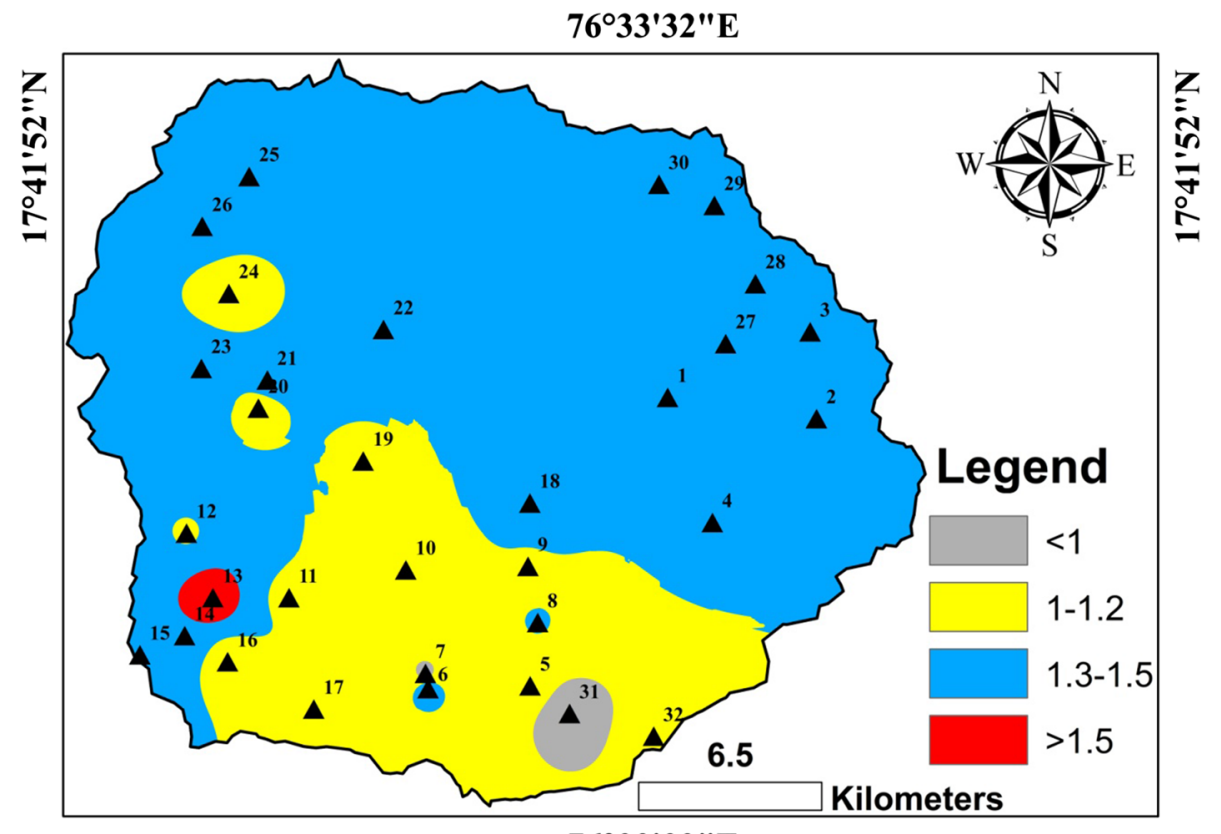

$7^{\circ} 33^{\prime} 32^{\prime \prime} \mathrm{E}$

Fig. 25 Geospatial distribution of fluoride (post-monsoon)

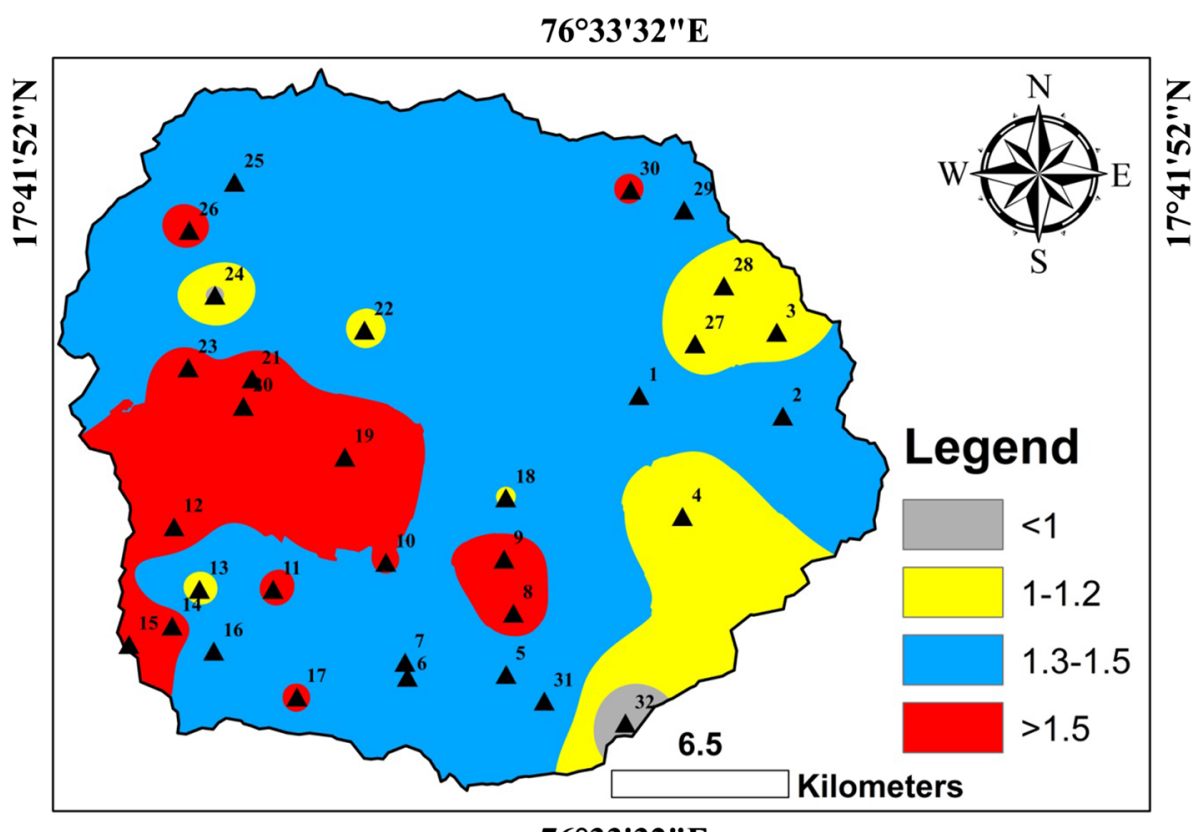

76³3'32"E dominance controls are seen for groundwater for both seasons.

\section{Irrigational suitability of groundwater}

The irrigational suitability of groundwater can be evaluated through the indices for salinity, chlorinity and sodicity. SAR, RSC, \%Na, Kelly's ratio, magnesium hazards, permeability index are the most critical indices in the estimating of groundwater for irrigational suitability. The higher concentration of sodium always affects the suitability for irrigation on the soil in respect of exchangeable calcium and magnesium ions. It can be evaluated by sodium soluble percentage (SSP), sodium absorption ratio (SAR), residual sodium carbonate (RSC) and \% $\mathrm{Na}$ indices.

\section{Soluble sodium percentage (SSP)}

Sodium in water replaces calcium in the soil through the base exchange process, which is responsible for decreasing 
Fig. 26 Geospatial distribution of nitrate (pre-monsoon)

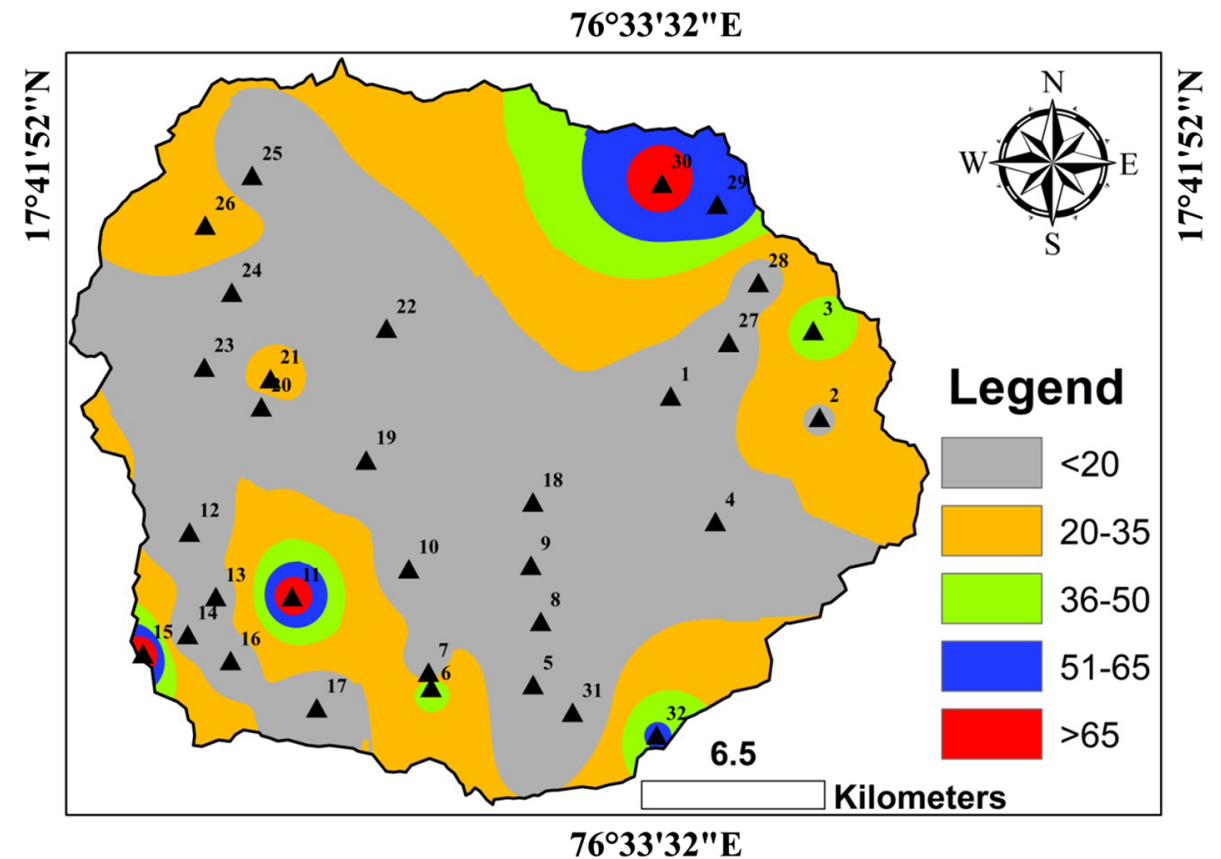

$76^{\circ} 332^{\prime \prime} \mathrm{E}$

Fig. 27 Geospatial distribution of nitrate (post-monsoon)

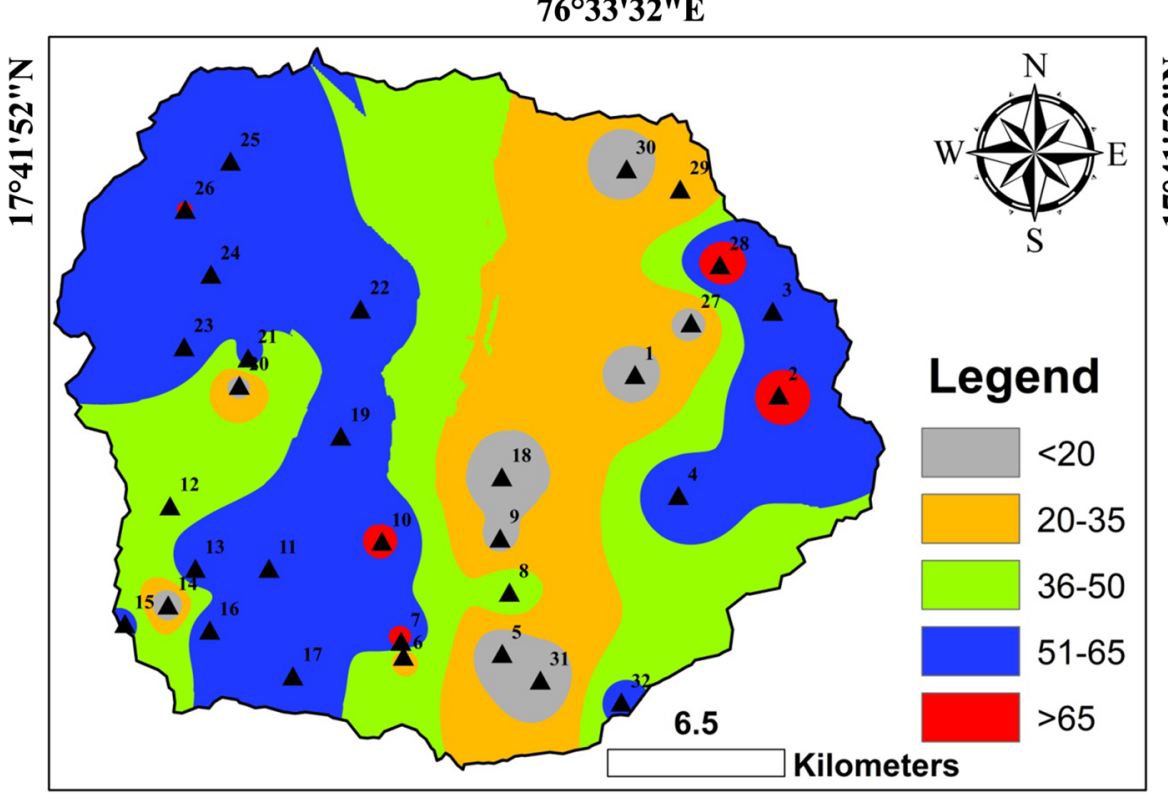

$7^{\circ} 33^{\prime} 32^{\prime \prime E}$ the soil permeability (Carroll 1962). Soluble sodium percentage (SSP) values less than or equal to 50 are considered as good quality for irrigation purpose. SSP values greater than 50 are unacceptable for irrigation as the permeability is very low in this case (Table 4). $100 \%$ of the samples were in the good quality class of SSP values in both the seasons. SSP can be evaluated by using Eq. (3).
$\mathrm{SSP}=\frac{\mathrm{Na} * 100}{\mathrm{Ca}+\mathrm{Mg}+\mathrm{Na}}$

where $\mathrm{Na}, \mathrm{Ca}, \mathrm{Mg}$ and $\mathrm{Na}$ are expressed in meq/l. 
Fig. 28 Geospatial distribution of sulphate (pre-monsoon)

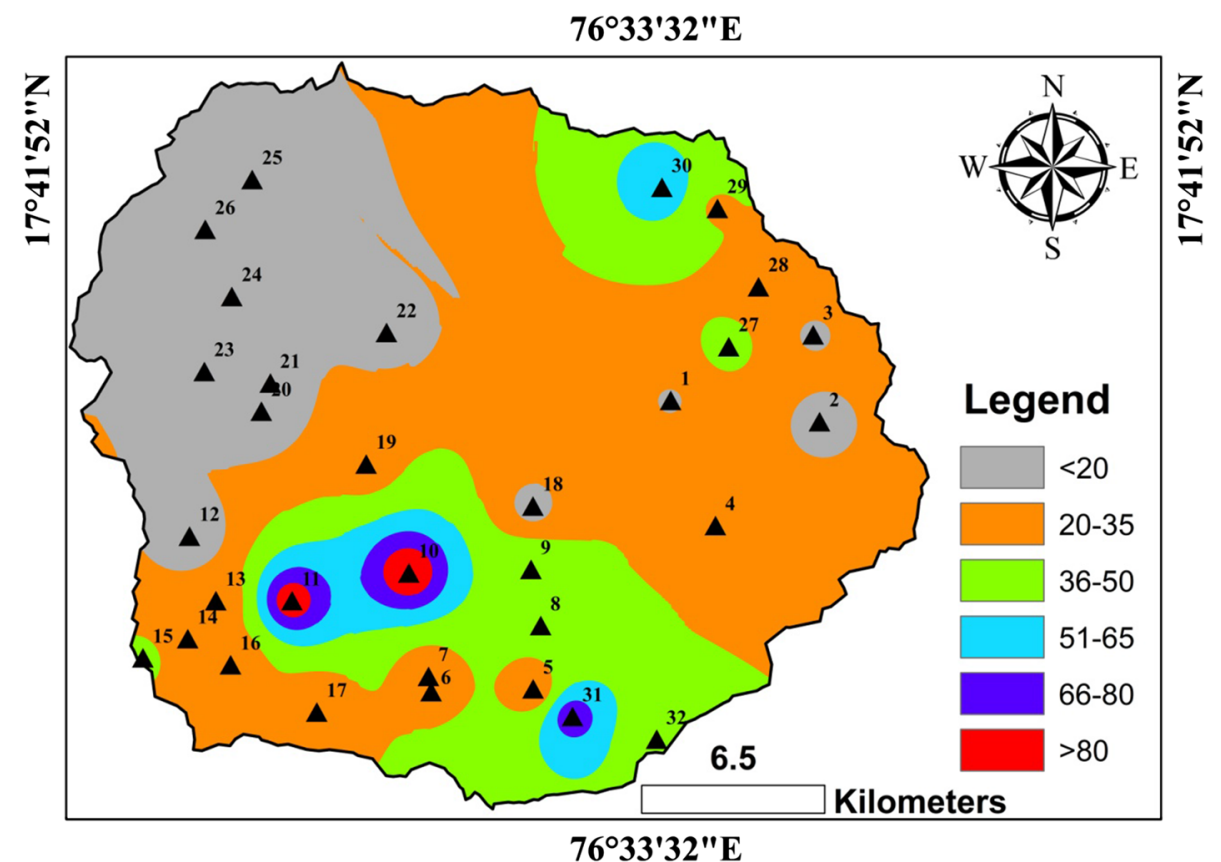

$7^{\circ} 33$ '32"E

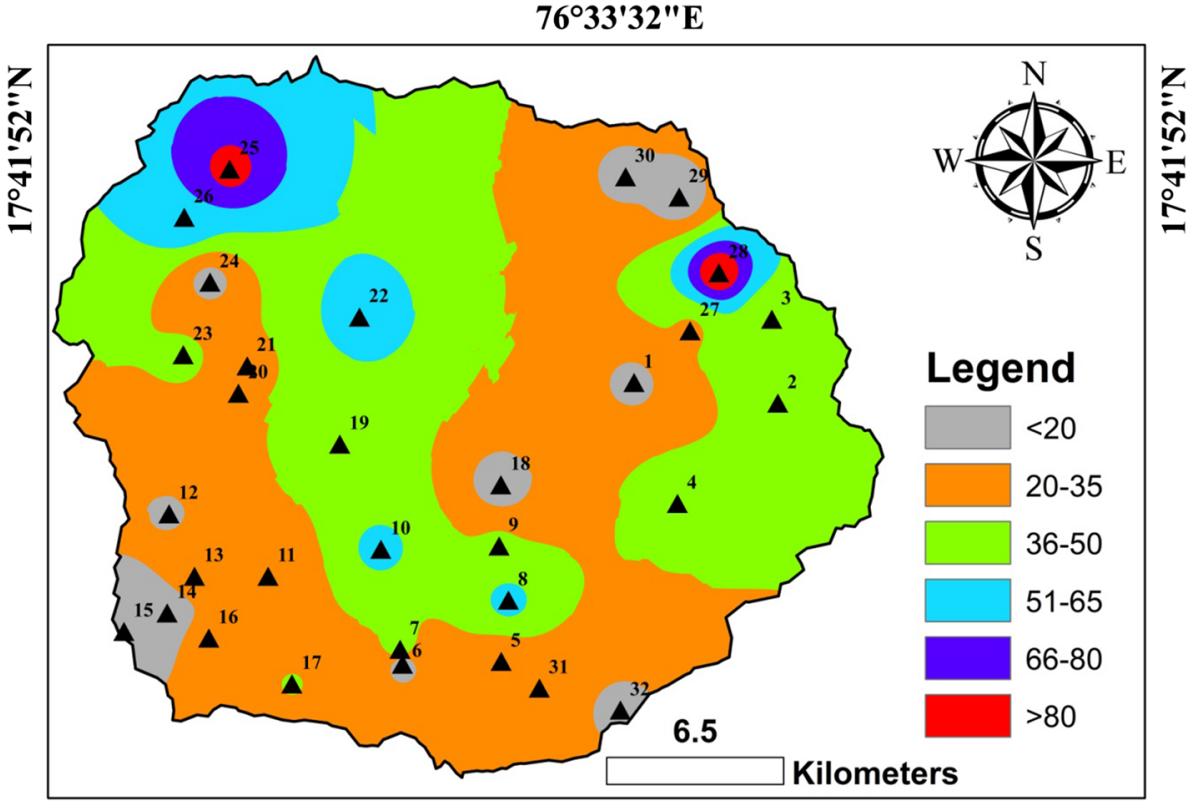

$7^{\circ} 33$ '32"E
Fig. 29 Geospatial distribution of sulphate (post-monsoon)

\section{Sodium absorption ratio (SAR)}

SAR values less than 10 would be suitable for irrigation, whereas greater than 10 would be not comfortable for irrigational purposes (Richards 1954). 100\% of groundwater samples of both seasons fall under the excellent class of SAR values (Table 4). SAR can be evaluated by using Eq. (4).
$\mathrm{SAR}=\frac{\mathrm{Na}}{\sqrt{ }(\mathrm{Ca}+\mathrm{Mg}) / 2}$

where $\mathrm{Na}, \mathrm{Ca}$ and $\mathrm{Mg}$ are expressed in meq/l. 
Fig. 30 Geospatial distribution of hardness (pre-monsoon)

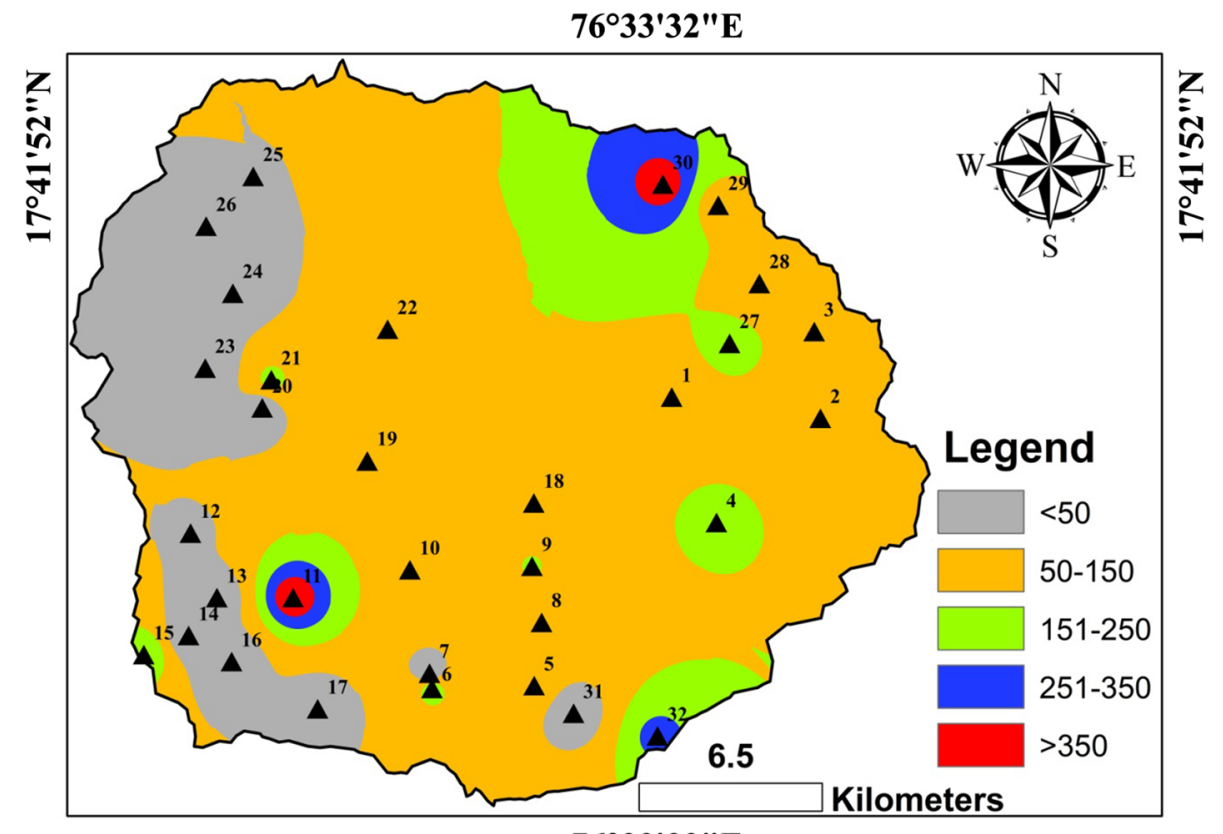

76'33'32"E

Fig. 31 Geospatial distribution of hardness (post-monsoon)

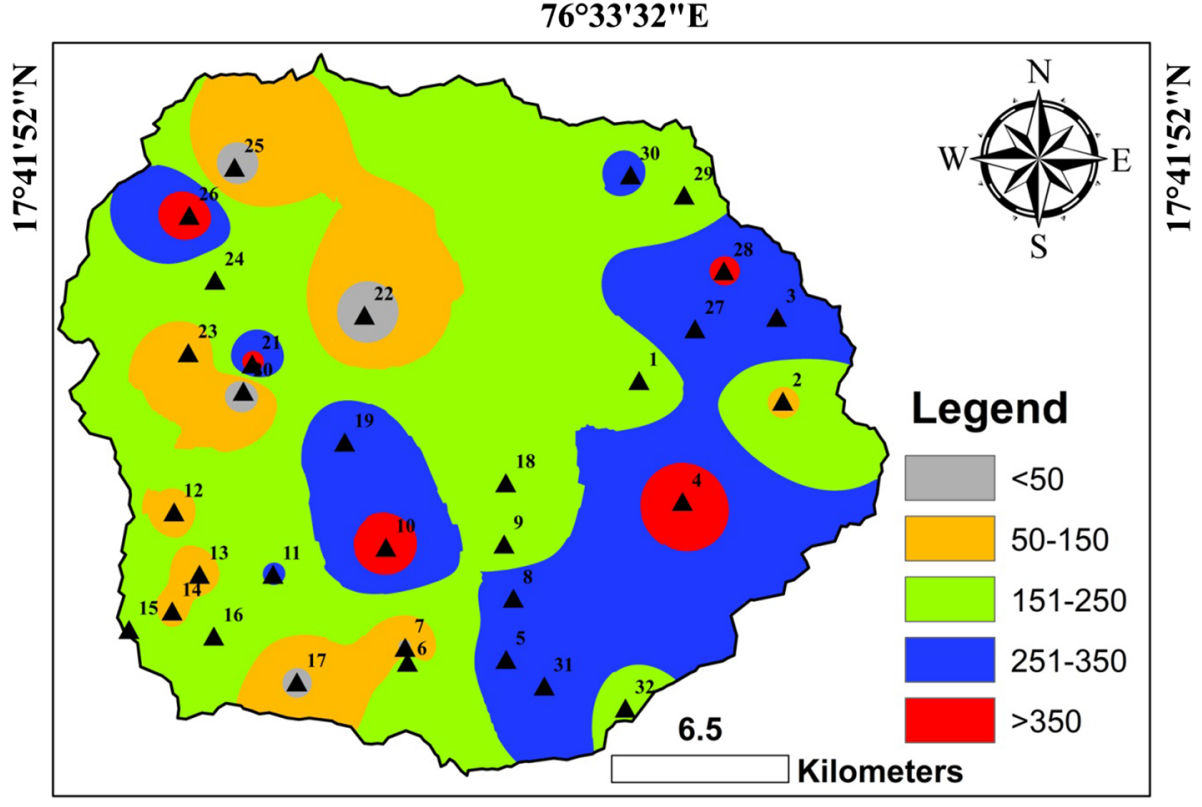

76³3'32"E

\section{Residual sodium carbonate (RSC)}

A higher concentration of carbonate causes calcium and magnesium to precipitate as bicarbonate in water (Ravikumar et al. 2011). The hazardous effect of carbonate and bicarbonate in water for agricultural purposes can be determined by residual sodium carbonate (RSC) analysis (Eaton 1950). According to RSC values (Table 4), $90.62 \%$ of groundwater samples belong to the safe category, whereas $9.38 \%$ of samples fall under marginal zone during the premonsoon season. In the post-monsoon season, $100 \%$ of the samples were categorised as a safe class of RSC values. A negative value of RSC indicates the higher concentrations of $\mathrm{Ca}$ and $\mathrm{Mg}$ in groundwater (Adimalla 2019). RSC can be evaluated (Eaton 1950) by using Eq. (5). 
Table 3 Suitability of drinking water in the study area as per BIS-2012 (IS-10500)

\begin{tabular}{|c|c|c|c|c|c|c|c|c|}
\hline \multirow[t]{2}{*}{ S. no. } & \multicolumn{2}{|l|}{ Parameters } & \multirow[t]{2}{*}{ Range } & \multicolumn{2}{|c|}{ Pre-monsoon } & \multirow{2}{*}{$\begin{array}{l}\text { BIS Standard (IS-10500) } \\
\text { (Acceptable Limit) Max }\end{array}$} & \multicolumn{2}{|c|}{ Post-monsoon } \\
\hline & & & & $\begin{array}{l}\text { No. of } \\
\text { samples }\end{array}$ & $(\%)$ & & $\begin{array}{l}\text { No. of } \\
\text { samples }\end{array}$ & $(\%)$ \\
\hline \multirow[t]{3}{*}{1} & \multirow{3}{*}{\multicolumn{2}{|c|}{$\mathrm{pH}$}} & $6.5-8.5$ & 29 & 90.62 & $6.5-8.5$ & 31 & 96.87 \\
\hline & & & $>8.5$ & 3 & 9.38 & & 1 & 3.13 \\
\hline & & & $<6.5$ & - & - & & - & - \\
\hline \multirow[t]{3}{*}{2} & \multirow{3}{*}{\multicolumn{2}{|c|}{$\mathrm{EC}(\mu \mathrm{S} / \mathrm{cm})$}} & $<500$ & 13 & 40.62 & - & 5 & 15.62 \\
\hline & & & $500-1000$ & 16 & 50 & & 25 & 78.13 \\
\hline & & & $>1000$ & 3 & 9.38 & & 2 & 6.25 \\
\hline \multirow[t]{2}{*}{3} & \multirow{2}{*}{\multicolumn{2}{|c|}{ Total dissolved solid (mg/L) }} & $<500$ & 25 & 78.12 & 500 & 21 & 65.62 \\
\hline & & & $>500$ & 7 & 21.88 & & 11 & 34.38 \\
\hline \multirow[t]{3}{*}{4} & \multirow{3}{*}{\multicolumn{2}{|c|}{ Calcium (mg/L) }} & $<75$ & 18 & 56.25 & 75 & 12 & 37.5 \\
\hline & & & $75-200$ & 11 & 34.38 & & 19 & 59.37 \\
\hline & & & $>200$ & 3 & 9.37 & & 1 & 3.13 \\
\hline \multirow[t]{3}{*}{5} & \multirow{3}{*}{\multicolumn{2}{|c|}{ Magnesium (mg/L) }} & $<30$ & 22 & 68.75 & 30 & 16 & 50 \\
\hline & & & $30-100$ & 10 & 31.25 & & 14 & 43.75 \\
\hline & & & $>100$ & - & & & 2 & 6.25 \\
\hline \multirow[t]{2}{*}{6} & \multirow{2}{*}{\multicolumn{2}{|c|}{ Sodium $(\mathrm{mg} / \mathrm{L})$}} & $<200$ & 32 & 100 & - & 32 & 100 \\
\hline & & & $>200$ & - & & & - & \\
\hline \multirow[t]{2}{*}{7} & \multirow{2}{*}{\multicolumn{2}{|c|}{ Potassium (mg/L) }} & $<40$ & 32 & 100 & - & 32 & 100 \\
\hline & & & $>40$ & - & & & - & \\
\hline \multirow[t]{2}{*}{8} & \multirow{2}{*}{\multicolumn{2}{|c|}{$\operatorname{Iron}(\mathrm{mg} / \mathrm{L})$}} & $<0.1$ & 32 & 100 & 0.3 & 32 & 100 \\
\hline & & & $>0.1$ & - & & & - & \\
\hline \multirow[t]{4}{*}{9} & \multirow[t]{4}{*}{ Alkalinity (mg/L) } & \multirow[t]{2}{*}{ Carbonate } & $<200$ & 32 & 100 & 200 & 32 & 100 \\
\hline & & & $>200$ & - & & & - & \\
\hline & & \multirow[t]{2}{*}{ Bicarbonate } & $<200$ & 26 & 81.25 & & 16 & 50 \\
\hline & & & $>200$ & 6 & 18.75 & & 16 & 50 \\
\hline 10 & Chloride (mg/L) & & $<250$ & 30 & 93.75 & 250 & 30 & 93.75 \\
\hline & & & $>250$ & 2 & 6.25 & & 2 & 6.25 \\
\hline 11 & Fluoride $(\mathrm{mg} / \mathrm{L})$ & & $<1$ & 2 & 6.25 & 1.0 & 2 & 6.25 \\
\hline & & & $1-1.5$ & 25 & 78.13 & & 29 & 90.62 \\
\hline & & & $>1.5$ & 5 & 15.62 & & 1 & 3.13 \\
\hline 12 & Nitrate $(\mathrm{mg} / \mathrm{L})$ & & $<45$ & 25 & 78.13 & 45 & 11 & 34.38 \\
\hline & & & $>45$ & 7 & 21.87 & & 21 & 65.62 \\
\hline 13 & Sulphate $(\mathrm{mg} / \mathrm{L})$ & & $<200$ & 32 & 100 & 200 & 32 & 100 \\
\hline & & & $>200$ & - & & & - & \\
\hline 14 & Hardness (mg/L) & & $<200$ & 14 & 43.75 & 200 & 12 & 37.5 \\
\hline & & & $200-500$ & 16 & 50 & & 20 & 62.5 \\
\hline & & & $>500$ & 2 & 6.25 & & - & \\
\hline
\end{tabular}

$\mathrm{RSC}=\left(\mathrm{HCO}_{3}+\mathrm{CO}_{3}\right)-(\mathrm{Ca}+\mathrm{Mg})$

where $\mathrm{HCO}_{3}, \mathrm{CO}_{3}, \mathrm{Ca}$ and $\mathrm{Mg}$ are expressed in meq/l.

\section{Percent sodium (\%Na)}

Percent sodium (\% Na) is also an important parameter to study sodium hazards. Soil permeability is reduced due to sodium (Joshi et al. 2009). According to the $\% \mathrm{Na}$ values (Table 4 ), $75 \%$ of samples were grouped into excellent class, $18.75 \%$ were in good, and $6.25 \%$ were in permissible classes of percentage sodium during pre-monsoon season. In the post-monsoon season, $90.62 \%$ of the samples were fallen into excellent, $6.25 \%$ samples in the good class, whereas $3.13 \%$ of the sample falls under permissible classes of $\% \mathrm{Na}$ values. \% Na can be evaluated (Wilcox 1955) by using Eq. (6). 
Fig. 32 Chadha's diagram (premonsoon)

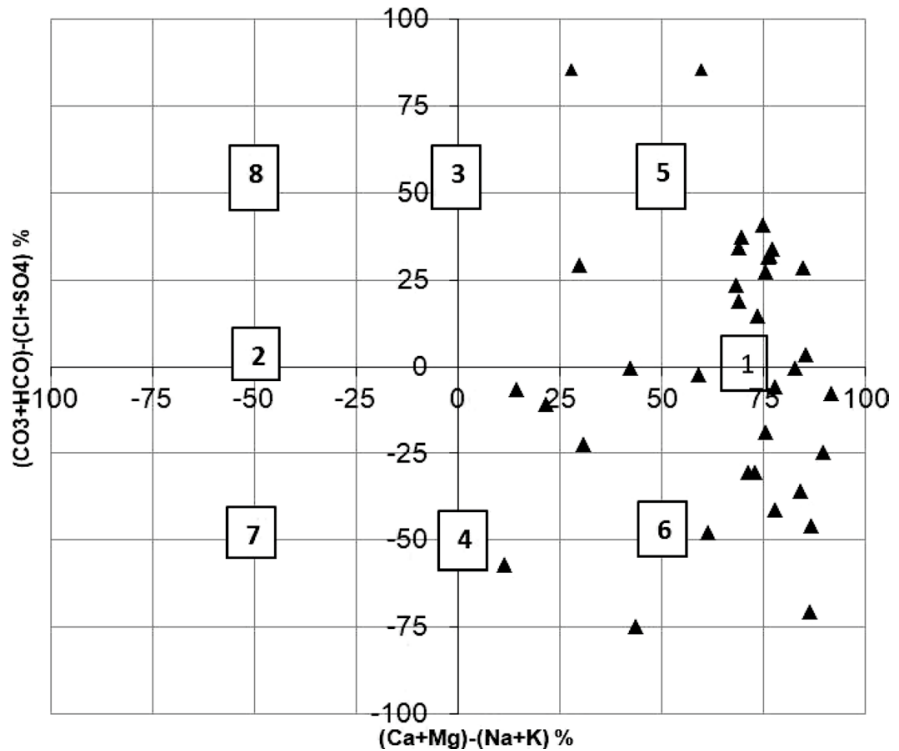

\begin{tabular}{|c|c|c|c|}
\hline \multirow[b]{2}{*}{$\begin{array}{l}\text { 1. Alkaline earths } \\
\text { exceed alkali metals } \\
(\mathrm{Ca}+\mathrm{Mg}>\mathrm{Na}+\mathrm{K})\end{array}$} & \multicolumn{2}{|c|}{$\begin{array}{l}\text { Hydrochemical } \\
\text { Facies for } \\
\text { Groundwater }\end{array}$} & \multirow[b]{2}{*}{$\begin{array}{l}\text { 4. Strong acidic } \\
\text { anions exceed weak } \\
\text { acidic anions } \\
\left(\mathrm{Cl}^{-}+\mathrm{SO}_{4}{ }^{2-}>\mathrm{CO}_{3}{ }^{2-}\right. \\
\left.+\mathrm{HCO}_{3}{ }^{-}\right)\end{array}$} \\
\hline & $\begin{array}{l}\text { 2. Alkali metals } \\
\text { exceeds alkaline } \\
\text { earths } \\
(\mathrm{Na}+\mathrm{K}>\mathrm{Ca}+\mathrm{Mg})\end{array}$ & $\begin{array}{l}\text { 3. Weak acidic anions } \\
\text { exceed strong acidic } \\
\text { anions } \\
\left(\mathrm{CO}_{3}{ }^{2-}+\mathrm{HCO}_{3}^{-}>\right. \\
\left.\mathrm{Cl}^{-}+\mathrm{SO}_{4}{ }^{2-}\right)\end{array}$ & \\
\hline $\begin{array}{c}\text { 5. } \mathrm{Ca}^{2+}-\mathrm{Mg}^{2+}-\mathrm{HCO}_{3}^{-} \\
\text {Water type } \\
\text { (Temporary hardness) }\end{array}$ & $\begin{array}{c}\text { 6. } \mathrm{Ca}^{2+}+\mathrm{Mg}^{2+}-\mathrm{Cl}^{-} \\
\text {Water type } \\
\text { (Permanent hardness) }\end{array}$ & $\begin{array}{l}\text { 7. } \mathrm{Na}^{+}-\mathrm{Cl}^{-} / \mathrm{SO}_{4}{ }^{2-} \\
\text { Water type } \\
\text { (Salinity problem) }\end{array}$ & $\begin{array}{l}\text { 8. } \mathrm{Na}^{+}-\mathrm{HCO}_{3}^{-} \\
\text {Water Type (Deposit } \\
\text { residual sodium } \\
\text { carbonate in irrigation } \\
\text { use) }\end{array}$ \\
\hline
\end{tabular}

$\% \mathrm{Na}=\frac{\mathrm{Na}+\mathrm{K}}{\mathrm{Ca}+\mathrm{Mg}+\mathrm{Na}+\mathrm{K}} * 100$

where $\mathrm{Na}, \mathrm{K}, \mathrm{Ca}$ and $\mathrm{Mg}$ are expressed in meq/l.

Wilcox diagram for both seasons is shown in Figs. 36 and 37 , respectively.

\section{Kelly's ratio (KR)}

Kelly's ratio (KR) is used for determining the sodium hazards on water quality for irrigational purpose (Kelly 1940). Table 4 represents the suitability classification of water for different seasons in the study area based on Kelly's ratio. $100 \%$ of the groundwater samples of both the seasons fell into the suitable class of Kelly's ratio values. Kelly's ratio can be evaluated by using Eq. (7).
Kelly's Ratio $=\frac{\mathrm{Na}}{\mathrm{Ca}+\mathrm{Mg}}$

where $\mathrm{Na}, \mathrm{Ca}$ and $\mathrm{Mg}$ are expressed in meq/l.

\section{Permeability index (PI)}

Soil permeability is affected due to through continuous use of water for irrigation as precipitation of certain elements in soil reduces the void space depending upon the quality, thereby hampering the water dynamics (Doneen 1964). Doneen proposed permeability index (PI) for characterising the suitability of irrigational water. It has been categorised into three classes. Class I (>75\%) and Class II $(25-75 \%)$ represents the waters suitable for irrigation with $75 \%$ or more of maximum permeability. In contrast, 
Fig. 33 Chadha's diagram (post-monsoon)

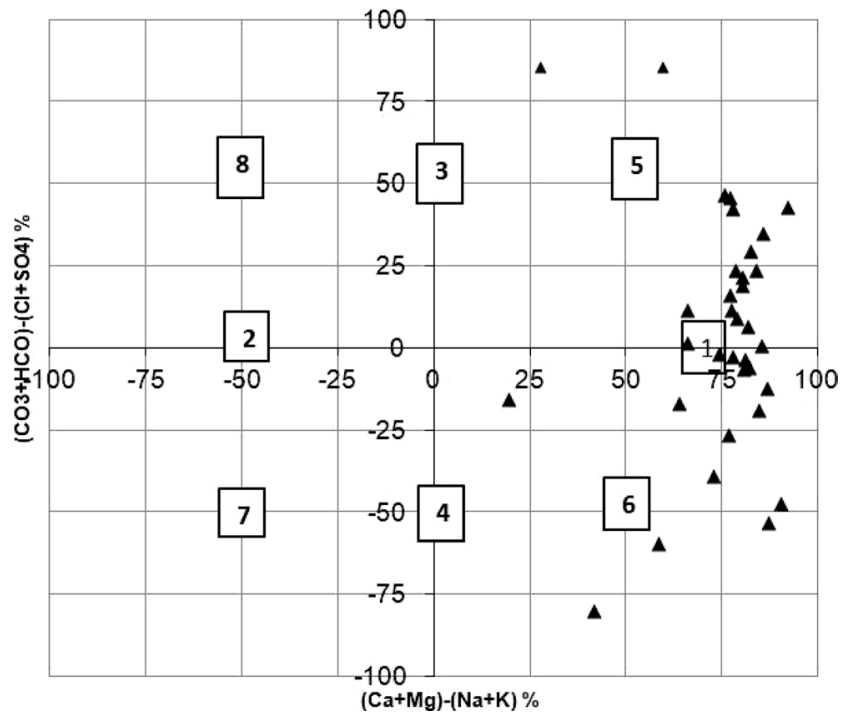

Hydrochemical

Facies for

Groundwater

1. Alkaline earths exceed alkali metals $(\mathrm{Ca}+\mathrm{Mg}>\mathrm{Na}+\mathrm{K})$

5. $\mathrm{Ca}^{2+}-\mathrm{Mg}^{2+}-\mathrm{HCO}_{3}^{-}$

Water type (Temporary hardness)
2. Alkali metals exceeds alkaline earths

$(\mathrm{Na}+\mathrm{K}>\mathrm{Ca}+\mathrm{Mg})$

6. $\mathrm{Ca}^{2+}+\mathrm{Mg}^{2+}-\mathrm{Cl}^{-}$

Water type (Permanent hardness)
3. Weak acidic anions exceed strong acidic anions

$$
\left(\mathrm{CO}_{3}{ }^{2-}+\mathrm{HCO}_{3}{ }^{-}>\right.
$$$$
\mathrm{Cl}^{-}+\mathrm{SO}_{4}{ }^{2-} \text { ) }
$$

7. $\mathrm{Na}^{+}-\mathrm{Cl}^{-} / \mathrm{SO}_{4}{ }^{2-}$ Water type

(Salinity problem)
4. Strong acidic anions exceed weak acidic anions

$\left(\mathrm{Cl}^{-}+\mathrm{SO}_{4}{ }^{2-}>\mathrm{CO}_{3}{ }^{2-}\right.$ $+\mathrm{HCO}_{3}{ }^{-}$)

8. $\mathrm{Na}^{+}-\mathrm{HCO}_{3}{ }^{-}$ Water Type (Deposit residual sodium carbonate in irrigation use)
Class III $(<25 \%)$ characterises the water unsuitable for irrigation with $25 \%$ of maximum permeability (Table 4 ). During pre-monsoon season, $18.75 \%$ of the samples enter to the Class III and unfit for irrigation purposes, whereas $68.75 \%$ samples belong to Class II and $12.5 \%$ fall under the Class I, shows suitability for irrigation purposes with maximum permeability. In the post-monsoon seasons, $34.37 \%$ of the samples belong to Class III, whereas $62.5 \%$ enter to Class II and $3.13 \%$ of the samples enter to the Class I. Permeability index can be evaluated by using Eq. (8).

$\mathrm{PI}=\frac{\mathrm{Na}+\left(\sqrt{\mathrm{HCO}_{3}}\right.}{\mathrm{Ca}+\mathrm{Mg}+\mathrm{Na}} * 100$

where $\mathrm{Na}, \mathrm{HCO}_{3}, \mathrm{Ca}$ and $\mathrm{Mg}$ are expressed in meq/l.

\section{Magnesium hazards (MH)}

Magnesium and calcium usually maintain a state of equilibrium in groundwater (Adimalla and Venkatayogi 2018). A higher concentration of magnesium in water can affects the soil quality through changing it into alkaline nature. During pre-monsoon season, $78.13 \%$ of the samples belong to the suitable class of irrigation according to $\mathrm{MH}$ values (Table 4 ), whereas $21.87 \%$ of the samples were categorised as unsuitable. $65.62 \%$ of the samples were grouped as a suitable class of irrigation, and $34.38 \%$ were belonging to the unsuitable class during post-monsoon seasons. Magnesium hazard ratio can be evaluated (Szabolcs and Darab 1964) by using Eq. (9). 
Fig. 34 Gibb's diagram (premonsoon), a Cations, b Anions

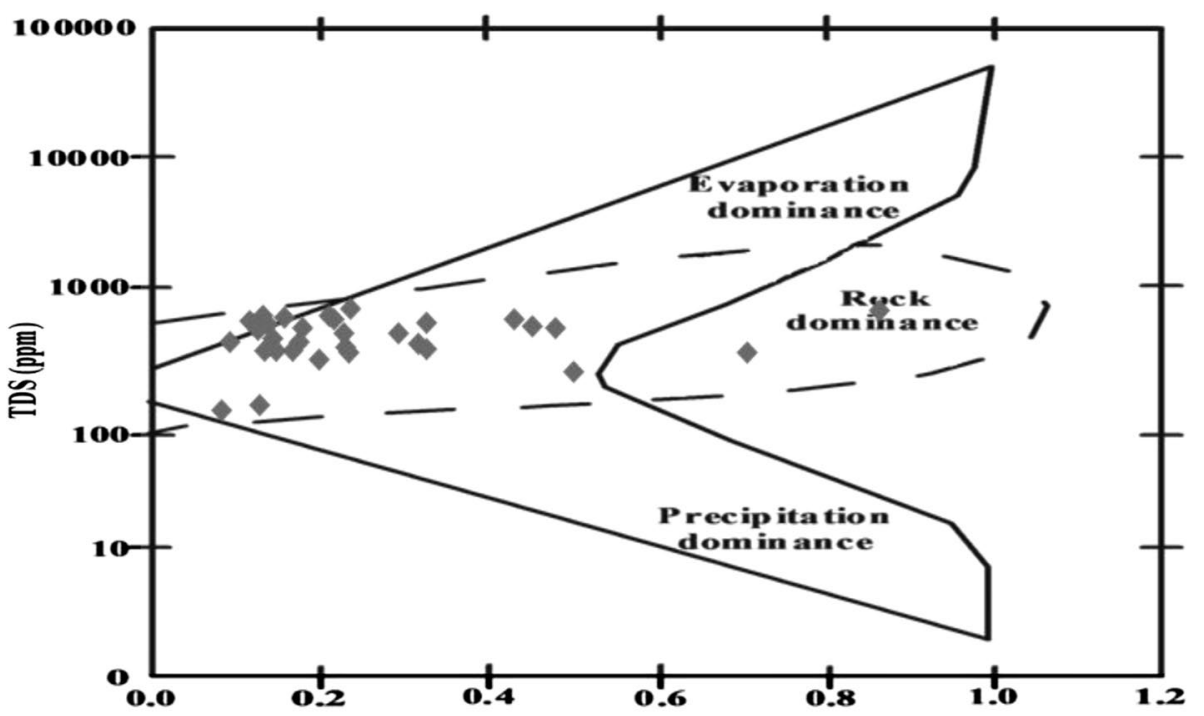

(A) Cations

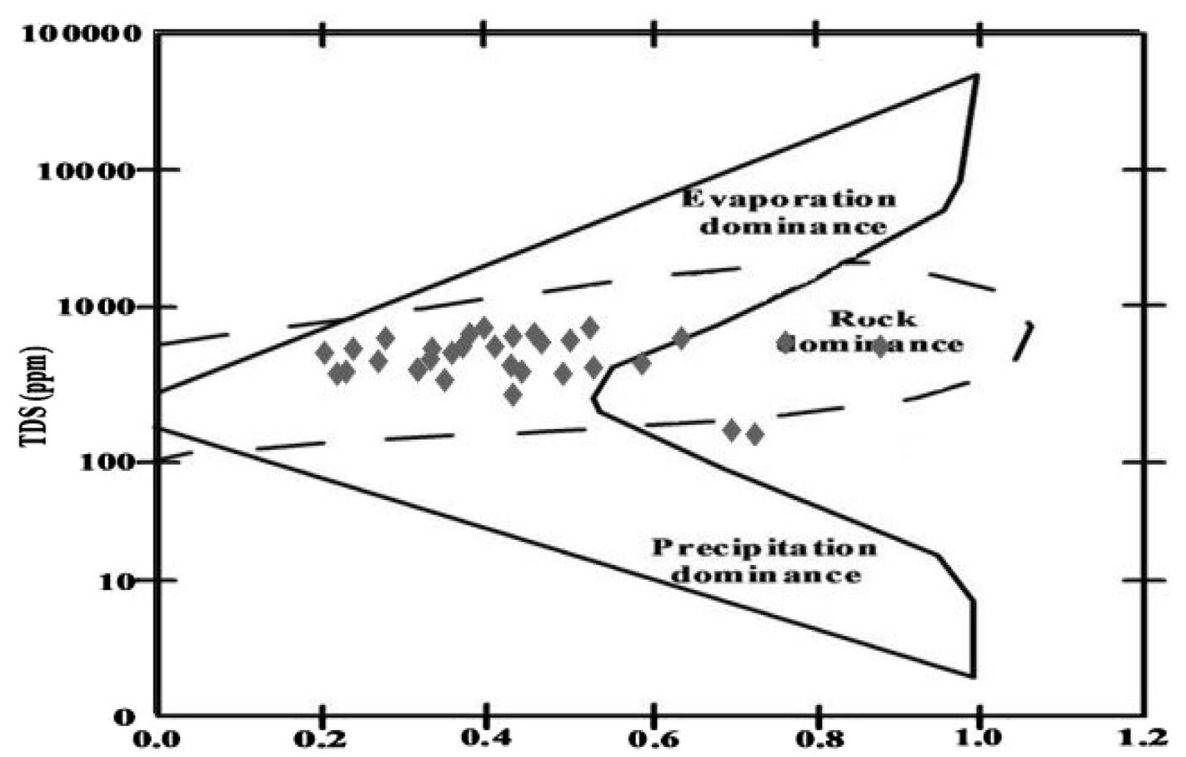

(B) Anions
Magnesium Hazard Ratio $=\frac{\mathrm{Mg}}{\mathrm{Ca}+\mathrm{Mg}} * 100$

where $\mathrm{Mg}$ and $\mathrm{Ca}$ are expressed in meq/l.

\section{Classification of irrigational suitability through US salinity diagram}

The electrical conductivity represents salinity hazards, whereas the sodium hazards are described in terms of sodium absorption ratio (SAR) on the USSL chart (USSL 1954). Excess sodium in water produces the undesirable effects of changing soil properties and reducing soil permeability (Adimalla and Venkatayogi 2018). Decreasing content of ions such as magnesium and calcium are often attributed with an increase in sodium which may result in high SAR values (Mohammad Muqtada et al. 2018). In the pre-monsoon season, $6.25 \%$ of groundwater samples fall into $\mathrm{C}_{1}-\mathrm{S}_{1}$ group of USSL diagram, which represents lowsalinity and low-sodium hazard zone, and this water is most suitable for irrigation purposes. $65.63 \%$ of samples belong to the category of $\mathrm{C}_{2}-\mathrm{S}_{1}$ which indicates medium-salinity hazards with low-alkaline water and this can be used for irrigation purposes with little impact of exchangeable sodium 
Fig. 35 Gibb's diagram (postmonsoon), a Cations b Anions

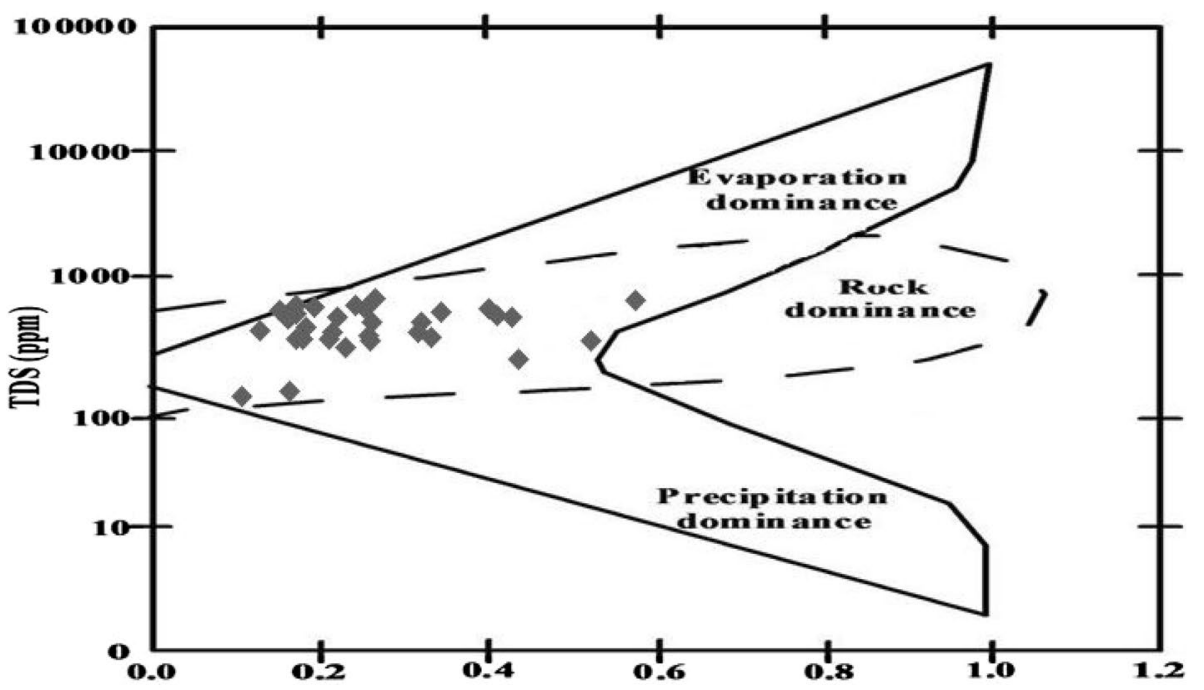

(A) Cations

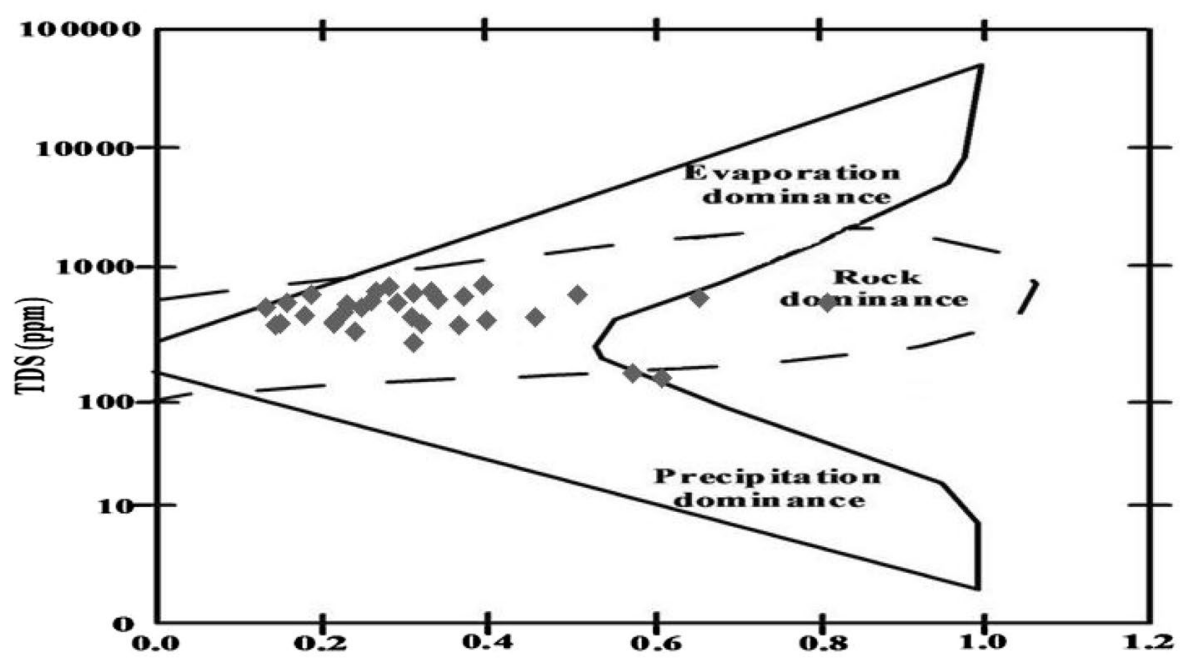

(B) Anions
(Adimalla and Venkatayogi 2018). 28.12\% samples fall into $\mathrm{C}_{3}-\mathrm{S}_{1}$ class which stand for high-salinity and low-alkaline water, and this type of water needs extensive treatment before applied to the soil irrigation due to high salinity (Adimalla 2019). During post-monsoon season, 6.25\% samples fall into $\mathrm{C}_{1}-\mathrm{S}_{1}$ class, $40.62 \%$ samples belong to $\mathrm{C}_{2}-\mathrm{S}_{1}$, and $53.13 \%$ samples fall into the category of $\mathrm{C}_{3}-\mathrm{S}_{1}$ (Figs. 38, $39)$. High levels of sodium ion in groundwater with relatively low levels of calcium ion are known to affect the subsurface structure, and degree of water is infiltrating the strata (Sadashivaiah et al. 2008). The summary of groundwater quality for irrigational purposes in both monsoon seasons is given in Tables 5 and 6 , respectively.

\section{Domestic suitability using hardness}

Domestic suitability of groundwater can be evaluated based on hardness of water (Durfor and Becker 1964). Table 7 represents the domestic suitability classification of water of different seasons based on hardness values in $\mathrm{mg} / \mathrm{L}$. In both monsoon seasons, $96.88 \%$ of groundwater samples fall into the soft water class, whereas $3.12 \%$ samples belong to moderately to hard water zone. Domestic suitability of water using hardness can be calculated (Durfor and Becker 1964) using Eq. (10).

Domestic Suitability $=\left(\mathrm{Ca}+\mathrm{Mg}-\mathrm{HCO}_{3}\right)$

where $\mathrm{Ca}, \mathrm{Mg}$ and $\mathrm{HCO}_{3}$ are expressed in $\mathrm{mg} / \mathrm{L}$. 
Table 4 Classification of groundwater based on irrigational water quality parameters

\begin{tabular}{|c|c|c|c|c|c|c|c|}
\hline \multirow[t]{2}{*}{ Parameters } & \multirow[t]{2}{*}{ Range } & \multirow[t]{2}{*}{ Class } & \multicolumn{4}{|c|}{ Number of samples } & \multirow[t]{2}{*}{ References } \\
\hline & & & Pre-monsoon & $(\%)$ & Post-monsoon & $(\%)$ & \\
\hline \multirow{4}{*}{$\begin{array}{l}\text { Electrical conductivity (EC) } \\
\mu \mathrm{S} / \mathrm{cm}\end{array}$} & $0-250$ & Low & 2 & 6.25 & 2 & 6.25 & Handa (1969) \\
\hline & $251-750$ & Medium & 23 & 71.88 & 15 & 46.87 & \\
\hline & $750-2250$ & High & 7 & 21.87 & 15 & 46.87 & \\
\hline & $2251-6000$ & Very high & 0 & & 0 & & \\
\hline \multirow{2}{*}{$\begin{array}{l}\text { Total dissolved solids (TDS) } \\
\text { mg/L }\end{array}$} & $<1000$ & Fresh water & 32 & 100 & 32 & 100 & Carroll (1962) \\
\hline & $1000-1500$ & Brackish water & - & & - & & \\
\hline \multirow{2}{*}{$\begin{array}{l}\text { Soluble sodium percentage } \\
\quad(\mathrm{SSP})(\mathrm{meq} / \mathrm{l})\end{array}$} & $\leq 50$ & Good quality & 32 & 100 & 32 & 100 & Carroll (1962) \\
\hline & $>50$ & Not suitable & - & & - & & \\
\hline \multirow{4}{*}{$\begin{array}{l}\text { Sodium absorption ratio (SAR) } \\
(\mathrm{meq} / \mathrm{l})\end{array}$} & $<10$ & Excellent & 32 & 100 & 32 & 100 & Richards (1954) \\
\hline & $10-18$ & Good & - & & - & & \\
\hline & $18-26$ & Permissible & - & & - & & \\
\hline & $>26$ & Doubtful & - & & - & & \\
\hline \multirow{3}{*}{$\begin{array}{l}\text { Residual sodium carbonate } \\
\text { (RSC) (meq/l) }\end{array}$} & $<1.25$ & Safe & 29 & 90.62 & 32 & 100 & Eaton (1950) \\
\hline & $1.25-2.5$ & Marginal & 3 & 9.38 & - & & \\
\hline & $>2.5$ & Unsuitable & - & & - & & \\
\hline \multirow[t]{5}{*}{ Percentage sodium $(\% \mathrm{Na})$} & $<20$ & Excellent & 24 & 75 & 29 & 90.62 & Wilcox (1955) \\
\hline & $20-40$ & Good & 6 & 18.75 & 2 & 6.25 & \\
\hline & $40-60$ & permissible & 2 & 6.25 & 1 & 3.13 & \\
\hline & $60-80$ & Doubtful & - & & - & & \\
\hline & $>80$ & Unsuitable & - & & - & & \\
\hline \multirow[t]{2}{*}{ Kelly’s ratio (KR) (meq/l) } & $<1$ & Suitable & 32 & 100 & 32 & 100 & Kelly (1940) \\
\hline & $>1$ & Unsuitable & - & & - & & \\
\hline \multirow[t]{3}{*}{ Permeability index (PI) (meq/l) } & Class III $(<25 \%)$ & Unsuitable & 6 & 18.75 & 11 & 34.37 & Doneen (1964) \\
\hline & Class II (25-75\%) & Suitable & 22 & 68.75 & 20 & 62.5 & \\
\hline & Class I (>75\%) & Suitable & 4 & 12.5 & 1 & 3.13 & \\
\hline \multirow[t]{2}{*}{ Magnesium hazards $(\mathrm{MH})$} & $<50$ & Suitable & 25 & 78.13 & 21 & 65.62 & Szabolcs and Darab (1964) \\
\hline & $>50$ & Unsuitable & 7 & 21.87 & 11 & 34.38 & \\
\hline
\end{tabular}

\section{Industrial suitability}

The industrial establishments are attracted in this region, due to special schemes in Hyderabad-Karnataka Region, wherein this area is located. Therefore, industrial Suitability has been done to check whether the samples are fit for the industrial suitability or not. The corrosivity ratio has been used to evaluate industrial usefulness (Table 7). Corrosion represents an electrolytic process through which metal surfaces are corroded (Devi et al. 2009). The result shows that $78.13 \%$ of samples were of suitable class $(<1)$, whereas $21.87 \%$ of samples were unsuitable $(>1)$ during pre-monsoon season. In the post-monsoon season, only $28.12 \%$ of groundwater samples fell into a suitable class, whereas $71.88 \%$ were into an unsuitable category. Corrosivity ratio can be evaluated (Badrinath et al. 1984) using Eq. (11).

Corrosivity Ratio $=\frac{\frac{\mathrm{Cl}}{35.5}+\frac{\mathrm{SO}_{4}}{48}}{\frac{\mathrm{CO}_{3}+\mathrm{HCO}_{3}}{50}}$

where $\mathrm{Cl}, \mathrm{SO}_{4}, \mathrm{CO}_{3}$ and $\mathrm{HCO}_{3}$ are expressed in $\mathrm{mg} / \mathrm{L}$.

\section{Collin's ratio}

Collin's ratio (CR) is used to check the suitability of water for drinking purposes. Water is suitable for drinking purposes if $\mathrm{CR}<1$. Water is considered as contaminated with 


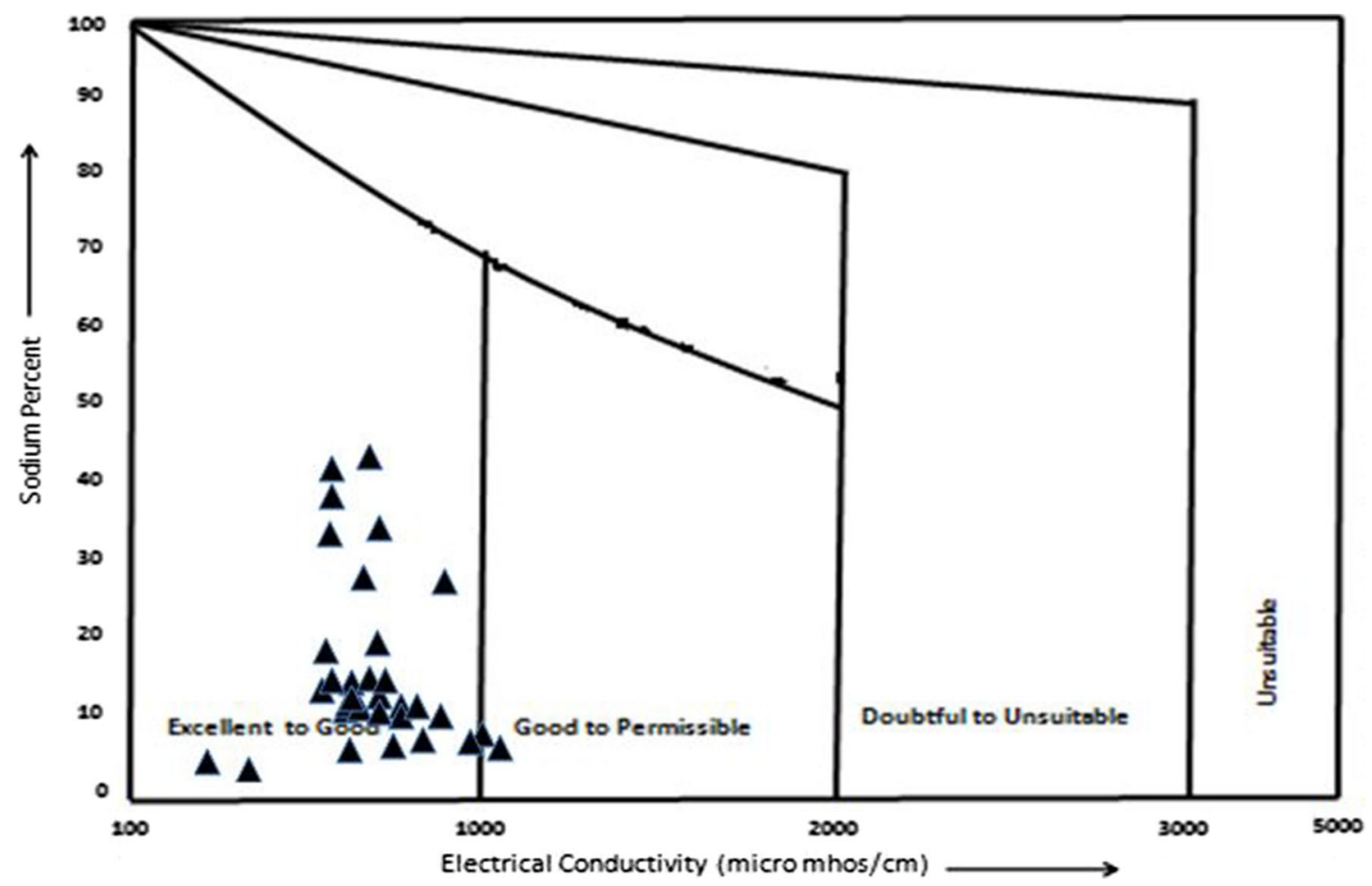

Fig. 36 Wilcox diagram (pre-monsoon)

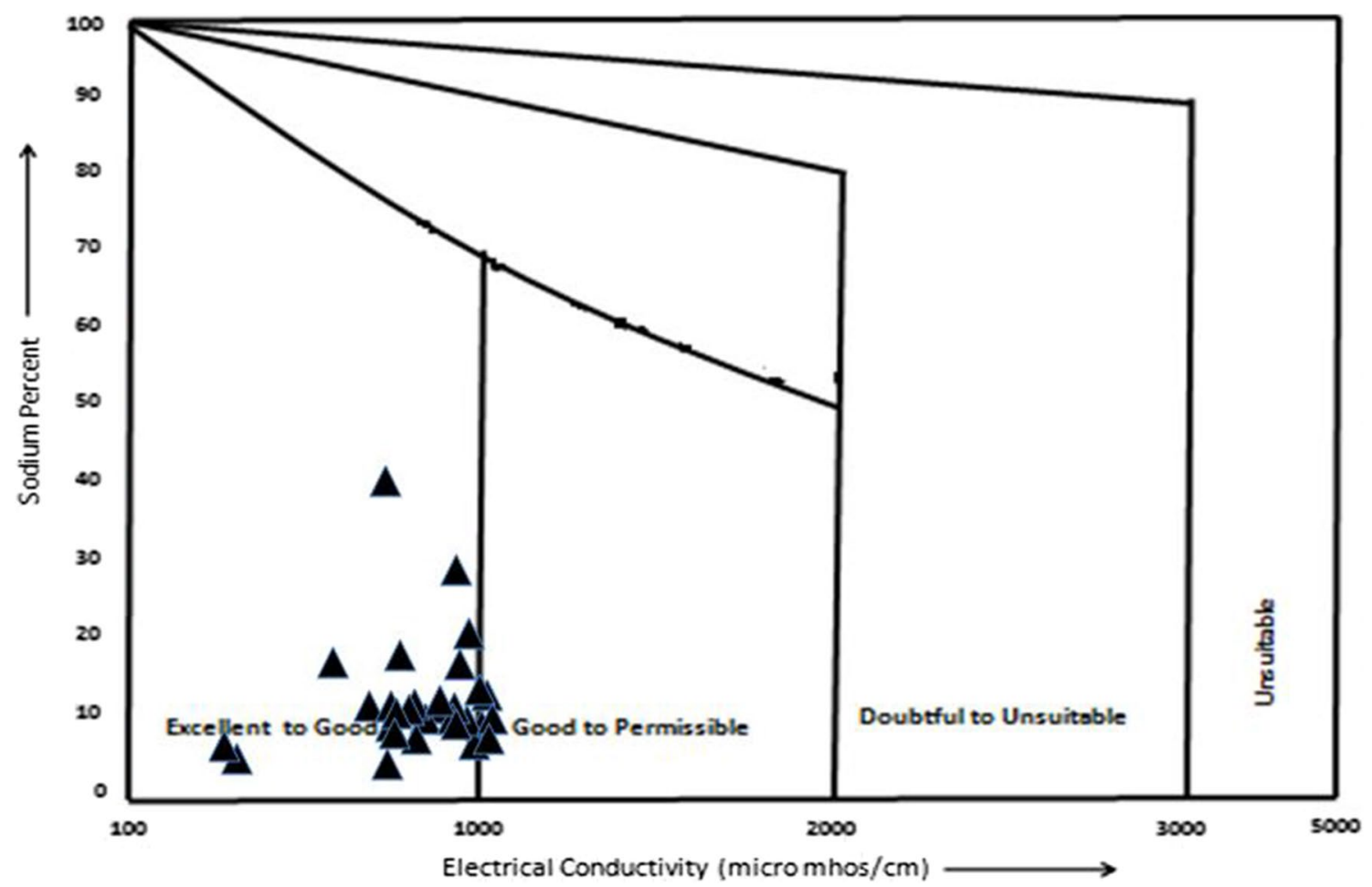

Fig. 37 Wilcox diagram (post-monsoon) 
Fig. 38 USSL diagram (premonsoon)

Fig. 39 USSL diagram (postmonsoon)

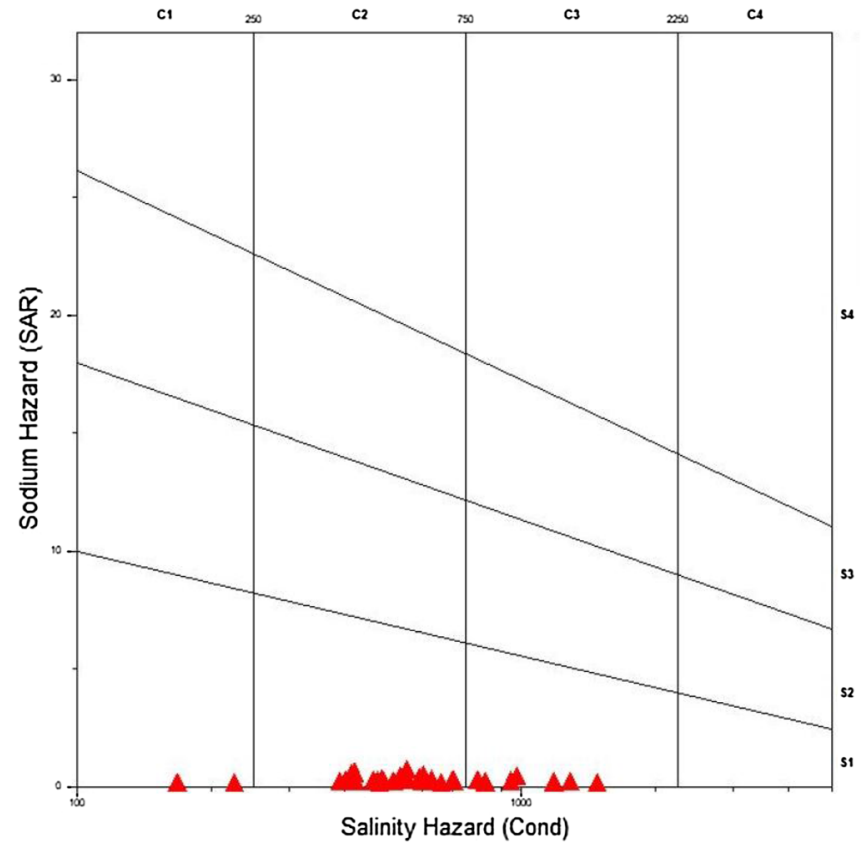

Water Sample

Sodium (Alkali) hazard:

S1: Low

S2: Medium

S3: High

S4: Very high

Salinity hazard:

C1: Low

C2: Medium

C3: High

C4: Very high

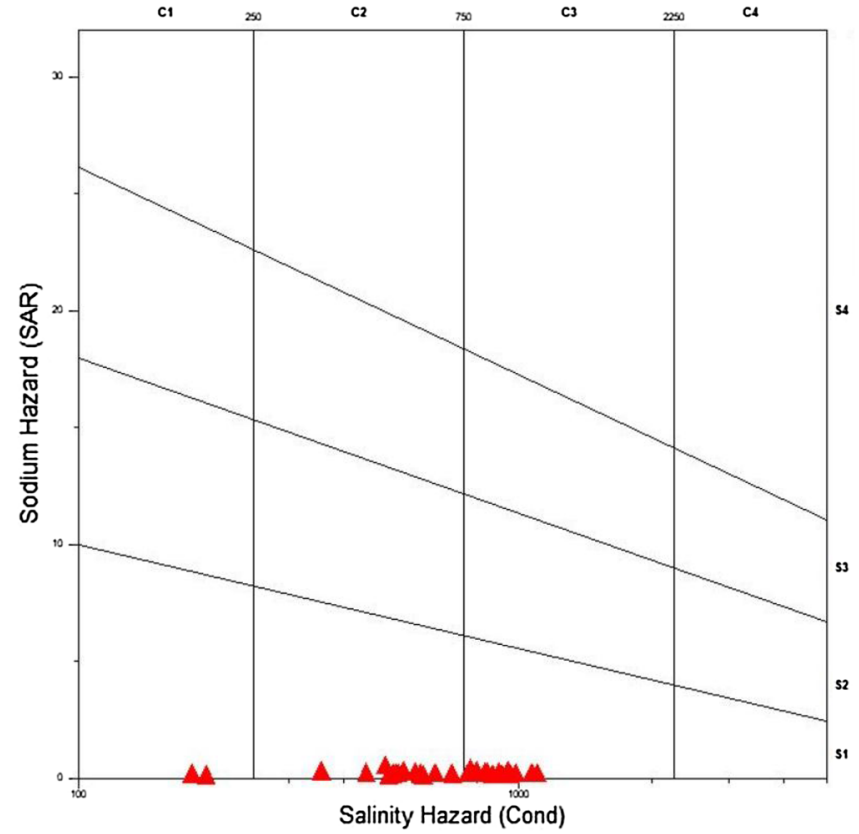

Aater Sample

Sodium (Alkali) hazard:

S1: Low

S2: Medium

S3: High

S4: Very high

Salinity hazard:

C1: Low

C2: Medium

C3: High

C4: Very high

saline water if the values of CR between 1 and 3 and injurious to health if $\mathrm{CR}>6.62 .5 \%$ of samples belong to the suitable class, whereas $37.5 \%$ samples were contaminated with saline water in the pre-monsoon season (Table 7). This may result due to the excess fertiliser activity within the region. In the post-monsoon season, $71.88 \%$ samples fall into a suitable class, whereas $25 \%$ of groundwater samples were contaminated with saline water and $3.12 \%$ fall into the healthy risk zone. Collin's ratio (proposed by Simpson 1946) of water can be calculated by using Eq. (12).

Collin's Ratio $=\frac{\mathrm{Cl}}{\mathrm{CO}_{3}}+\mathrm{HCO}_{3}$

where $\mathrm{Cl}, \mathrm{CO}_{3}$ and $\mathrm{HCO}_{3}$ are expressed in meq/l.

Domestic and industrial suitability of groundwater of different monsoons is given in Tables 8 and 9, respectively. 
Table 5 Pre-monsoon irrigational suitability of groundwater

\begin{tabular}{|c|c|c|c|c|c|c|c|}
\hline S. no. & SSP $\%$ & SAR & RSC & $\% \mathrm{Na}$ & $\begin{array}{l}\text { Kelly's ratio } \\
\text { (KR) }\end{array}$ & $\begin{array}{l}\text { Magnesium } \\
\text { hazards (MH) }\end{array}$ & $\begin{array}{l}\text { Permeability } \\
\text { index (PI) }\end{array}$ \\
\hline 1 & 6.76 & 0.27 & -3.92 & 11.96 & 0.07 & 20.00 & 29.63 \\
\hline 2 & 9.30 & 0.35 & -2.36 & 15.41 & 0.10 & 45.18 & 36.92 \\
\hline 3 & 6.56 & 0.26 & -3.74 & 12.44 & 0.07 & 71.17 & 30.64 \\
\hline 4 & 3.53 & 0.17 & -7.43 & 7.39 & 0.04 & 21.71 & 19.77 \\
\hline 5 & 6.90 & 0.28 & -4.06 & 11.21 & 0.07 & 26.54 & 29.30 \\
\hline 6 & 4.99 & 0.23 & -4.29 & 8.73 & 0.05 & 63.85 & 27.85 \\
\hline 7 & 31.49 & 0.73 & 0.15 & 44.43 & 0.46 & 36.17 & 83.92 \\
\hline 8 & 7.60 & 0.30 & -3.83 & 13.66 & 0.08 & 18.45 & 30.43 \\
\hline 9 & 4.02 & 0.20 & -9.49 & 6.91 & 0.04 & 3.92 & 15.75 \\
\hline 10 & 6.14 & 0.27 & -5.17 & 11.15 & 0.07 & 19.33 & 25.83 \\
\hline 11 & 2.48 & 0.17 & -13.15 & 4.35 & 0.03 & 21.44 & 15.77 \\
\hline 12 & 9.73 & 0.32 & -1.20 & 16.06 & 0.11 & 27.88 & 44.97 \\
\hline 13 & 22.44 & 0.55 & 1.67 & 34.73 & 0.29 & 33.99 & 93.40 \\
\hline 14 & 25.22 & 0.61 & 0.81 & 39.38 & 0.34 & 26.21 & 93.42 \\
\hline 15 & 4.18 & 0.21 & -3.54 & 7.84 & 0.04 & 53.76 & 27.61 \\
\hline 16 & 28.90 & 0.61 & 1.60 & 42.94 & 0.41 & 7.40 & 118.43 \\
\hline 17 & 21.81 & 0.53 & 2.35 & 35.28 & 0.28 & 8.96 & 36.49 \\
\hline 18 & 7.15 & 0.27 & -2.76 & 12.73 & 0.08 & 69.06 & 33.24 \\
\hline 19 & 7.14 & 0.24 & -2.54 & 14.52 & 0.08 & 71.34 & 33.28 \\
\hline 20 & 18.49 & 0.48 & 0.01 & 29.03 & 0.23 & 46.20 & 68.07 \\
\hline 21 & 7.35 & 0.30 & -4.08 & 12.42 & 0.08 & 60.25 & 29.04 \\
\hline 22 & 8.87 & 0.32 & -0.83 & 15.71 & 0.10 & 45.77 & 43.53 \\
\hline 23 & 6.47 & 0.24 & -2.81 & 12.14 & 0.07 & 32.65 & 33.57 \\
\hline 24 & 10.21 & 0.28 & -2.22 & 19.52 & 0.11 & 20.48 & 32.47 \\
\hline 25 & 8.48 & 0.28 & -1.45 & 15.68 & 0.09 & 42.55 & 41.60 \\
\hline 26 & 12.39 & 0.41 & -2.08 & 20.65 & 0.14 & 43.86 & 42.76 \\
\hline 27 & 4.52 & 0.22 & -8.42 & 8.12 & 0.05 & 20.03 & 18.09 \\
\hline 28 & 6.07 & 0.24 & -3.30 & 11.60 & 0.06 & 30.92 & 31.30 \\
\hline 29 & 7.72 & 0.31 & -3.87 & 13.44 & 0.08 & 36.02 & 29.93 \\
\hline 30 & 3.00 & 0.19 & -14.02 & 5.34 & 0.03 & 40.89 & 14.12 \\
\hline 31 & 17.36 & 0.46 & -1.36 & 28.38 & 0.21 & 0.00 & 44.91 \\
\hline 32 & 3.74 & 0.19 & -9.87 & 6.79 & 0.04 & 50.90 & 16.50 \\
\hline
\end{tabular}

Bold values are representing the 'higher concentration' of the parameters

\section{Rainfall water quality linkage}

An attempt has been made to correlate the hydrochemical parameters with the rainfall. In this concern, maximum annual rainfall data in the study area of 2016 were collected from the Karnataka State Natural Disaster Monitoring Centre (KSNDMC) website. The maximum rainfall in Aland was noted in July (108 mm) and September (107 mm), whereas the minimum rain was recorded in January $(4.5 \mathrm{~mm})$. Although the region has come under a semi-arid zone, it is also well known for scanty rainfall. Correlation analysis has been done to check the variations of positive and negative ions to the rainfall. Figure 40 depicts the maximum annual rainfall in the study area. The relationship between rainfall, physical parameters, positive and negative ions of all the location is shown in Figs. 41, 42 and 43, respectively. The result indicates that the rainfall within the study area does not influence water quality. The main reason could be the texture and type of soil presents in the region. The result is further confirmed by the Gibbs's plot of both seasons where it is clearly shown that rock dominance factor is controlling the groundwater chemistry and there is no effect of precipitation. Calcium and magnesium concentrations in groundwater play a significant role in the estimation of groundwater quality, and $\mathrm{Mg}$ can give more adverse effects on soils than calcium (Adimalla 2019). Runoff pattern can also influence the water quality. 
Table 6 Post-monsoon irrigational suitability of groundwater

\begin{tabular}{|c|c|c|c|c|c|c|c|}
\hline S. no. & SSP $\%$ & SAR & RSC & $\% \mathrm{Na}$ & $\begin{array}{l}\text { Kelly's ratio } \\
\text { (KR) }\end{array}$ & $\begin{array}{l}\text { Magnesium } \\
\text { hazards (MH) }\end{array}$ & $\begin{array}{l}\text { Permeability } \\
\text { index (PI) }\end{array}$ \\
\hline 1 & 6.89 & 0.27 & -3.90 & 11.53 & 0.07 & 33.17 & 30.04 \\
\hline 2 & 7.85 & 0.32 & -3.81 & 12.94 & 0.09 & 3.64 & 31.32 \\
\hline 3 & 4.57 & 0.20 & -3.26 & 8.83 & 0.05 & 54.51 & 30.21 \\
\hline 4 & 3.81 & 0.19 & -7.60 & 6.60 & 0.04 & 37.86 & 20.10 \\
\hline 5 & 5.72 & 0.26 & -5.82 & 9.53 & 0.06 & 21.35 & 24.74 \\
\hline 6 & 5.81 & 0.23 & -2.26 & 11.20 & 0.06 & 28.31 & 35.45 \\
\hline 7 & 10.57 & 0.29 & -1.50 & 20.89 & 0.12 & 17.79 & 47.12 \\
\hline 8 & 7.53 & 0.30 & -4.32 & 13.56 & 0.08 & 63.12 & 28.84 \\
\hline 9 & 6.25 & 0.25 & -3.21 & 11.36 & 0.07 & 42.74 & 32.38 \\
\hline 10 & 4.30 & 0.23 & -9.40 & 7.64 & 0.04 & 64.27 & 18.05 \\
\hline 11 & 5.33 & 0.23 & -5.22 & 9.81 & 0.06 & 22.79 & 25.51 \\
\hline 12 & 9.90 & 0.33 & -1.79 & 16.96 & 0.11 & 54.31 & 42.77 \\
\hline 13 & 6.24 & 0.22 & -3.07 & 11.71 & 0.07 & 22.31 & 32.21 \\
\hline 14 & 5.62 & 0.20 & -2.03 & 11.43 & 0.06 & 21.08 & 36.47 \\
\hline 15 & 3.72 & 0.16 & -5.07 & 7.21 & 0.04 & 13.68 & 24.65 \\
\hline 16 & 5.61 & 0.24 & -4.55 & 9.83 & 0.06 & 11.08 & 26.37 \\
\hline 17 & 11.25 & 0.34 & -1.56 & 18.08 & 0.13 & 2.31 & 44.29 \\
\hline 18 & 9.73 & 0.33 & -2.60 & 17.00 & 0.11 & 58.62 & 37.52 \\
\hline 19 & 5.61 & 0.25 & -5.08 & 9.76 & 0.06 & 47.53 & 26.31 \\
\hline 20 & 26.31 & 0.56 & 0.80 & 40.36 & 0.36 & 3.38 & 111.05 \\
\hline 21 & 5.63 & 0.24 & -3.77 & 10.53 & 0.06 & 86.29 & 29.86 \\
\hline 22 & 17.52 & 0.44 & -1.41 & 29.11 & 0.21 & 13.57 & 50.39 \\
\hline 23 & 5.03 & 0.21 & -5.39 & 9.02 & 0.05 & 23.84 & 24.17 \\
\hline 24 & 5.94 & 0.22 & -1.49 & 12.16 & 0.06 & 52.13 & 39.52 \\
\hline 25 & 2.74 & 0.15 & 10.81 & 4.84 & 0.03 & 59.41 & 15.52 \\
\hline 26 & 3.80 & 0.19 & -8.05 & 7.38 & 0.04 & 37.76 & 19.40 \\
\hline 27 & 7.34 & 0.30 & -4.57 & 11.06 & 0.08 & 60.26 & 28.27 \\
\hline 28 & 4.33 & 0.22 & -8.65 & 6.37 & 0.05 & 14.65 & 18.73 \\
\hline 29 & 2.35 & 0.15 & 16.87 & 4.00 & 0.02 & 81.84 & 11.23 \\
\hline 30 & 6.17 & 0.24 & -3.12 & 10.64 & 0.07 & 62.96 & 32.71 \\
\hline 31 & 5.13 & 0.24 & -6.22 & 9.06 & 0.05 & 19.32 & 23.47 \\
\hline 32 & 5.00 & 0.23 & -6.02 & 8.08 & 0.05 & 38.93 & 23.46 \\
\hline
\end{tabular}

Bold values are representing the 'higher concentration' of the parameters

Table 7 Water suitability for different purposes using different parameters

\begin{tabular}{|c|c|c|c|c|c|c|}
\hline \multirow[t]{2}{*}{ Suitability } & \multirow[t]{2}{*}{ Parameters } & \multirow[t]{2}{*}{ Range } & \multirow[t]{2}{*}{ Class } & \multicolumn{2}{|c|}{ Number of samples } & \multirow[t]{2}{*}{ References } \\
\hline & & & & Pre-monsoon & Post-monsoon & \\
\hline \multirow[t]{4}{*}{ Domestic suitability } & \multirow[t]{4}{*}{ Hardness (mg/L) } & $<60$ & Soft water & $31(96.88 \%)$ & $31(96.88 \%)$ & \multirow[t]{4}{*}{$\begin{array}{l}\text { Durfor and Becker } \\
\quad(1964)\end{array}$} \\
\hline & & $60-120$ & Moderately hard water & $1(3.12 \%)$ & $1(3.12 \%)$ & \\
\hline & & $120-180$ & Hard water & - & - & \\
\hline & & $>180$ & Very hard water & - & - & \\
\hline \multirow[t]{2}{*}{ Industrial suitability } & \multirow[t]{2}{*}{ Corrosivity ratio (mg/L) } & $\leq 1$ & Corrosive & $25(78.13 \%)$ & $9(28.12 \%)$ & \multirow[t]{2}{*}{ Badrinath et al. (1984) } \\
\hline & & $>1$ & Non-corrosive & $7(21.87 \%)$ & $23(71.88 \%)$ & \\
\hline \multirow{3}{*}{$\begin{array}{l}\text { Drinking water suit- } \\
\text { ability }\end{array}$} & \multirow[t]{3}{*}{ Collin's ratio (meq/l) } & $\leq 1$ & Suitable & $20(62.5 \%)$ & $23(71.88 \%)$ & \multirow[t]{3}{*}{ Simpson (1946) } \\
\hline & & $1-3$ & $\begin{array}{l}\text { Contaminated with } \\
\text { saline water }\end{array}$ & $12(37.5 \%)$ & $8(25 \%)$ & \\
\hline & & $>6$ & Injurious to health & - & $1(3.12 \%)$ & \\
\hline
\end{tabular}


Table 8 Domestic and industrial suitability of groundwater (premonsoon season)

\begin{tabular}{|c|c|c|c|c|}
\hline Well no. & Location name & $\begin{array}{l}\text { Industry suitability using } \\
\text { corrosivity ratio }\end{array}$ & $\begin{array}{l}\text { Domestic suitability } \\
\text { using hardness }\end{array}$ & Collin's ratio \\
\hline 1 & Telikuni & 0.15 & -57.62 & 0.34 \\
\hline 2 & Kinnisultan & 0.07 & -96.71 & 0.31 \\
\hline 3 & Jamga R & 0.93 & -95 & 0.40 \\
\hline 4 & Aland & 1.52 & -0.76 & 0.72 \\
\hline 5 & Gulahalli & 0.31 & -57.15 & 0.90 \\
\hline 6 & Jidga & 1.64 & -165.69 & 0.79 \\
\hline 7 & Jamga Khandala & 0.17 & -34.61 & 3.17 \\
\hline 8 & Shakhapur & 0.77 & -36.04 & 1.49 \\
\hline 9 & Jheerahalli & 1.99 & 105.908 & 5.07 \\
\hline 10 & Khanapur & 0.69 & -37.57 & 1.58 \\
\hline 11 & Swaleshwar & 1.08 & -192.99 & 0.91 \\
\hline 12 & Sarasamba & 0.12 & -103.97 & 0.57 \\
\hline 13 & Nagelagaon & 0.12 & -137.23 & 1.37 \\
\hline 14 & Sakkarga & 0.19 & -105.02 & 0.97 \\
\hline 15 & Kamanalli & 0.46 & -295.59 & 0.41 \\
\hline 16 & Kinnihabas & 0.07 & -100.19 & 0.88 \\
\hline 17 & Mogha B & 0.01 & 28.29 & 0.40 \\
\hline 18 & Hebli & 0.06 & -94.96 & 0.29 \\
\hline 19 & Padsawli & 0.15 & -49.64 & 1.53 \\
\hline 20 & Chincholi K & 0.09 & -75.72 & 0.89 \\
\hline 21 & Chincholi B & 0.27 & -58.34 & 1.26 \\
\hline 22 & Nirgudi & 0.08 & -161.74 & 0.38 \\
\hline 23 & Khairat & 0.15 & -87.87 & 0.39 \\
\hline 24 & Varnalwadi & 0.15 & 21.35 & 2.20 \\
\hline 25 & Aloor & 0.08 & -84.36 & 0.53 \\
\hline 26 & Bolegaon & 1.71 & -56.77 & 0.79 \\
\hline 27 & Chitali & 0.83 & 54.54 & 1.65 \\
\hline 28 & Bangerga & 0.16 & -95.46 & 0.24 \\
\hline 29 & Bableshwar & 0.13 & -45.09 & 0.40 \\
\hline 30 & Khajuri & 2.68 & 35.63 & 1.26 \\
\hline 31 & Tadola & 0.29 & 8.96 & 4.81 \\
\hline 32 & Korahalli & 4.39 & 30.18 & 2.30 \\
\hline
\end{tabular}

Bold values are representing the 'higher concentration' of the parameters

Minus sign indicating the soft water using hardness $\left(\mathrm{as}^{\mathrm{CaCO}}{ }_{3}\right)$

\section{Conclusion}

Drinking water suitability of groundwater around the catchment was not good except at few places. The $\mathrm{pH}$ of groundwater was close to the permissible limit in both monsoon seasons with exceeding at some locations. A higher concentration of TDS, $\mathrm{Ca}, \mathrm{Mg}, \mathrm{HCO}_{3}, \mathrm{Cl}, \mathrm{NO}_{3}$ and hardness were recorded except in few cases. At most of the locations, fluoride concentrations were close to the permissible limit with exceeding few places during pre-monsoon and post-monsoon seasons. Fluoride-affected areas in both the monsoon seasons were noticed as Telikuni $(1.48 \mathrm{mg} / \mathrm{L})$ village, Kinnisultan $(1.49 \mathrm{mg} / \mathrm{L})$, Aland $(1.50 \mathrm{mg} / \mathrm{L})$, Jidga $(1.51 \mathrm{mg} / \mathrm{L})$, Padsawli (1.54 mg/L), Nagelagaon (1.97 mg/L), Sakkarga (1.64 mg/L), Kamanalli (1.58 mg/L), Hebli (1.49 mg/L), Khairat $91.49 \mathrm{mg} / \mathrm{L})$ and Jheerahalli $(1.46 \mathrm{mg} / \mathrm{L})$ village. The highest concentration of fluoride was recorded in Nagelagaon (1.97 mg/L) during pre-monsoon and Padsawli 
Table 9 Domestic and industrial suitability of groundwater (postmonsoon season)

\begin{tabular}{|c|c|c|c|c|}
\hline Well no. & Location name & $\begin{array}{l}\text { Industry suitability using } \\
\text { corrosivity ratio }\end{array}$ & $\begin{array}{l}\text { Domestic suitability } \\
\text { using hardness }\end{array}$ & Collin's ratio \\
\hline 1 & Telikuni & 1.17 & -48.94 & 0.54 \\
\hline 2 & Kinnisultan & 1.69 & -52.03 & 0.77 \\
\hline 3 & Jamga R & 0.88 & -191.47 & 0.39 \\
\hline 4 & Aland & 2.09 & -28.88 & 1.01 \\
\hline 5 & Gulahalli & 1.74 & -48.7 & 0.88 \\
\hline 6 & Jidga & 0.66 & -151.81 & 0.32 \\
\hline 7 & Jamga Khandala & 6.42 & -36.6 & 3.26 \\
\hline 8 & Shakhapur & 3.70 & -45.22 & 1.77 \\
\hline 9 & Jheerahalli & 1.29 & -108.08 & 0.56 \\
\hline 10 & Khanapur & 2.40 & -14.1 & 1.12 \\
\hline 11 & Swaleshwar & 1.10 & -45.35 & 0.50 \\
\hline 12 & Sarasamba & 1.29 & -96.71 & 0.59 \\
\hline 13 & Nagelagaon & 0.64 & -36.48 & 1.39 \\
\hline 14 & Sakkarga & 0.08 & -94.78 & 0.28 \\
\hline 15 & Kamanalli & 0.79 & -45.34 & 0.37 \\
\hline 16 & Kinnihabas & 0.09 & -41.02 & 0.45 \\
\hline 17 & Mogha B & 0.18 & -38.39 & 1.00 \\
\hline 18 & Hebli & 1.57 & -52.99 & 0.76 \\
\hline 19 & Padsawli & 1.85 & -85.48 & 0.85 \\
\hline 20 & Chincholi K & 2.25 & -99.93 & 0.98 \\
\hline 21 & Chincholi B & 1.36 & -160.36 & 0.66 \\
\hline 22 & Nirgudi & 14.81 & -3.61 & 7.33 \\
\hline 23 & Khairat & 1.84 & -12.73 & 0.80 \\
\hline 24 & Varnalwadi & 0.59 & -172.9 & 0.26 \\
\hline 25 & Aloor & 4.57 & 2.7 & 2.32 \\
\hline 26 & Bolegaon & 1.62 & -17.64 & 0.61 \\
\hline 27 & Chitali & 1.72 & -52.8 & 0.76 \\
\hline 28 & Bangerga & 5.34 & 29.87 & 2.68 \\
\hline 29 & Bableshwar & 0.65 & 67.72 & 0.28 \\
\hline 30 & Khajuri & 1.01 & -107.38 & 0.46 \\
\hline 31 & Tadola & 1.44 & -38.16 & 0.70 \\
\hline 32 & Korahalli & 1.01 & -40.33 & 0.46 \\
\hline
\end{tabular}

Bold values are representing the 'higher concentration' of the parameters Minus sign indicating the soft water using hardness (as $\mathrm{CaCO}_{3}$ )

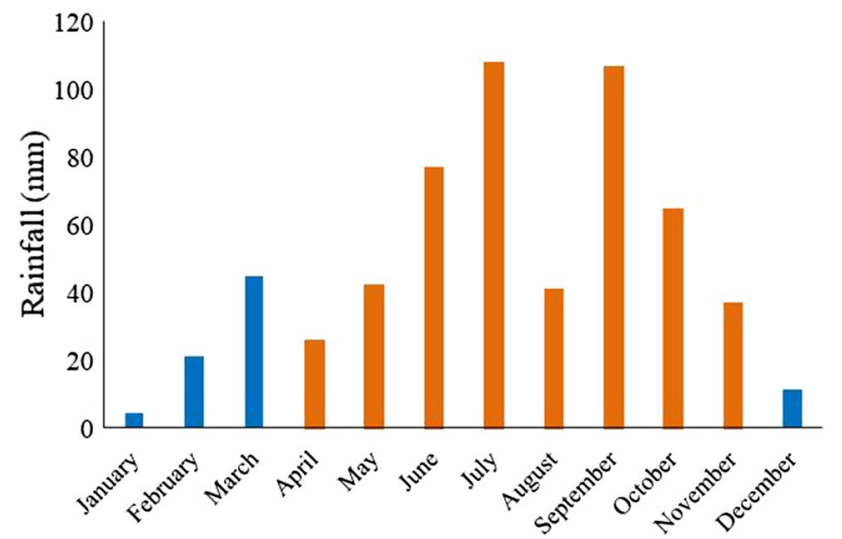

Fig. 40 Maximum annual rainfall in the study area (2016) village $(1.54 \mathrm{mg} / \mathrm{L})$ during post-monsoon. Environmental awareness programme for the health implications of fluoride in the study area may be conducted from time to time by the stakeholders concerned. Highest nitrate concentration was recorded in Kamanalli $(96 \mathrm{mg} / \mathrm{L})$ village during pre-monsoon, whereas Jamga Khandala $(77 \mathrm{mg} / \mathrm{L})$ village during post-monsoon.

Irrigational suitability of groundwater showed that the water is within the limit for irrigation except in a few locations. The USSL diagram illustrated the salinity hazards and suggested the need for unique soil management before use. Gibb's plot indicates that groundwater chemistry is controlled by rock dominance factor for both seasons. Geochemical classification of groundwater 
Fig. 41 Relationship between the maximum rainfall and physical parameters of the study area

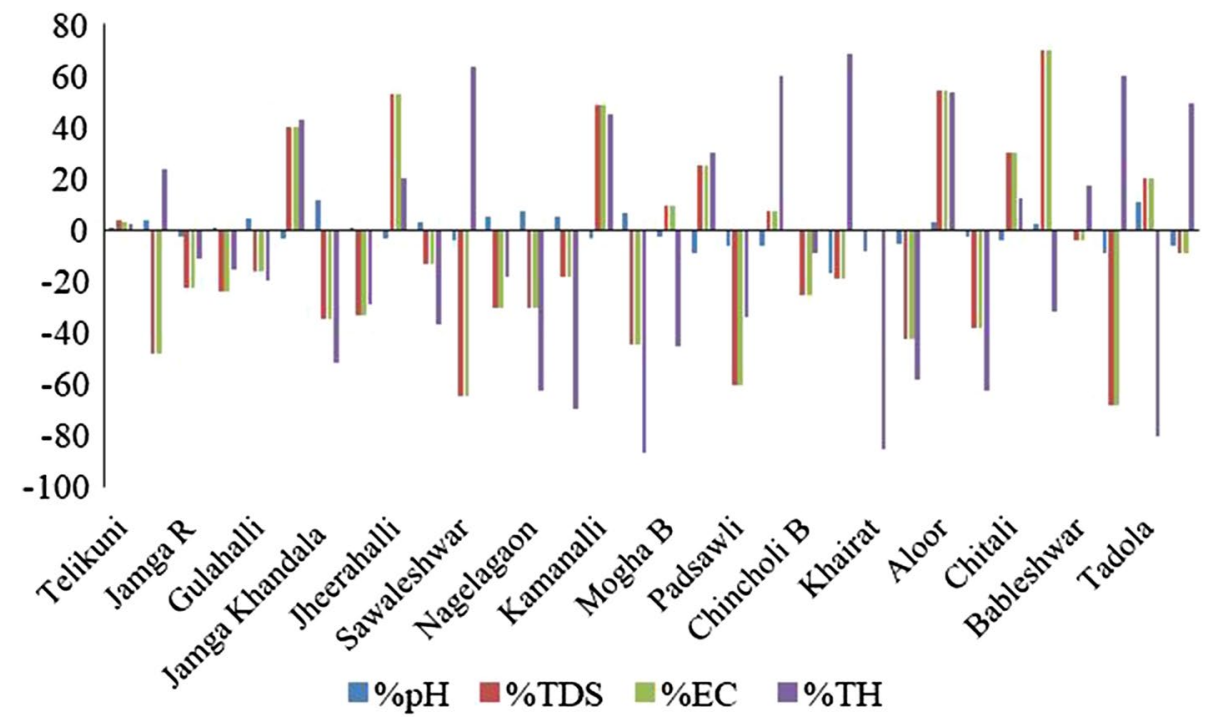

Fig. 42 Relationship between the maximum rainfall and positive ions of both the seasons

Fig. 43 Relationship between the maximum rainfall and negative ions of both the seasons
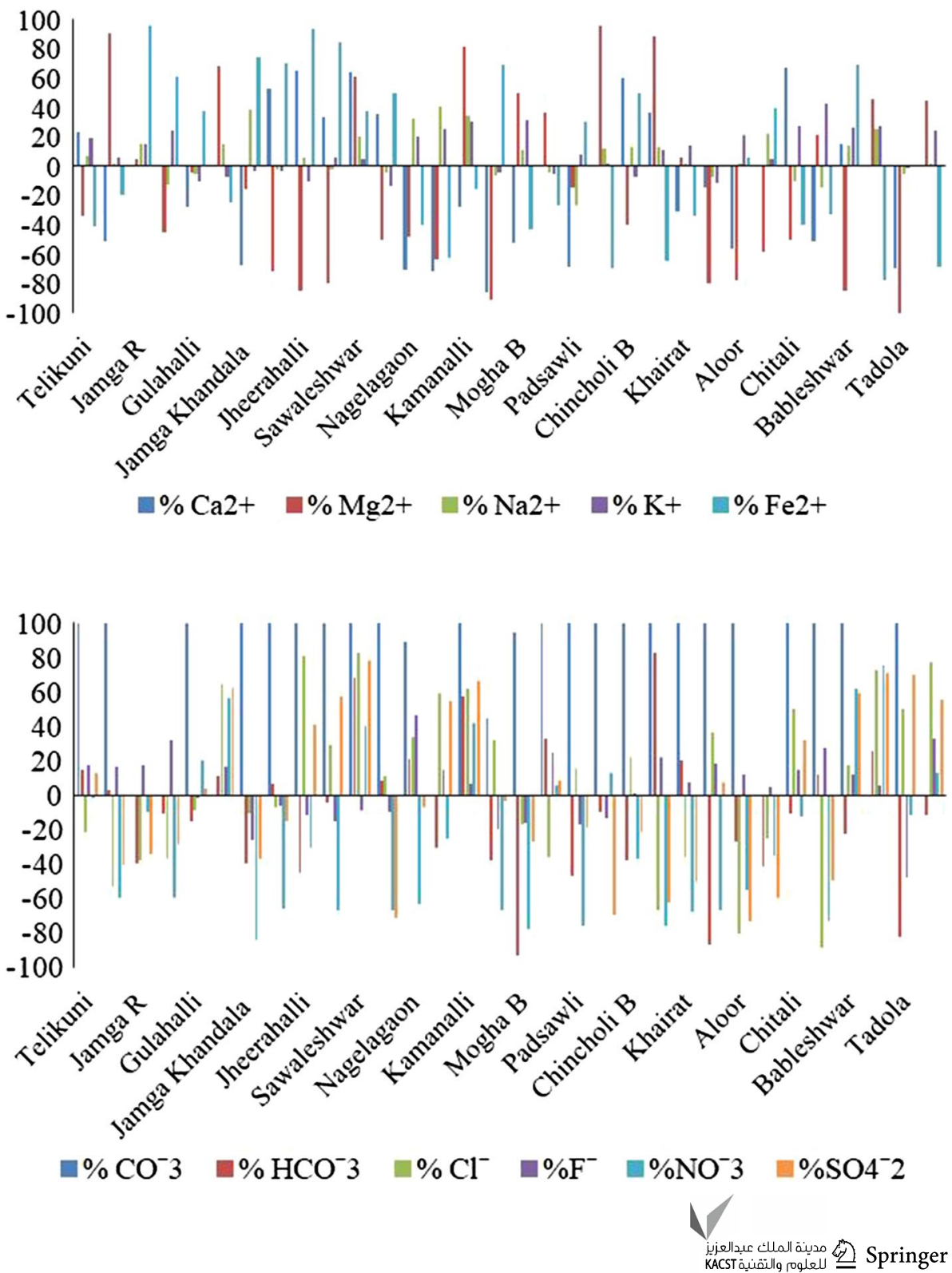
using Chadha's diagram is indicating $\mathrm{Ca}^{2+}-\mathrm{Mg}^{2+}-\mathrm{Cl}^{-}$and $\mathrm{Ca}^{2+}-\mathrm{Mg}^{2+}-\mathrm{HCO}_{3}{ }^{-}$water type for both seasons. Correlation analysis showed that water quality within the region is not influenced by rainfall which is further confirmed by Gibb's plot. Overall, the water quality analysis revealed that the groundwater quality of catchment was not good for the public health point of view. Therefore, community awareness programme and steady survey through municipalities' is needed for a safeguard public health. The lower part of the catchment requires proper management for groundwater before utilising for domestic purposes. GIS-based spatial distribution maps are useful in the better understanding of mapping the vulnerable zones of the catchment for adopting a better management strategy.

Acknowledgements The authors would like to express his special thanks to the Enrico Driol, Editor-in-Chief, for his quick response. The authors further extend their gratitude to the reviewers for their valuable comment and suggestions.

Funding The authors received no specific funding for this work.

\section{Compliance with ethical standards}

\section{Conflict of interest None.}

Open Access This article is licensed under a Creative Commons Attribution 4.0 International License, which permits use, sharing, adaptation, distribution and reproduction in any medium or format, as long as you give appropriate credit to the original author(s) and the source, provide a link to the Creative Commons licence, and indicate if changes were made. The images or other third party material in this article are included in the article's Creative Commons licence, unless indicated otherwise in a credit line to the material. If material is not included in the article's Creative Commons licence and your intended use is not permitted by statutory regulation or exceeds the permitted use, you will need to obtain permission directly from the copyright holder. To view a copy of this licence, visit http://creativecommons.org/licenses/by/4.0/.

\section{References}

Adimalla N (2019) Groundwater quality for drinking and irrigation purposes and potential health risks assessment: a case study from semi-arid region of South India. Expo Health 11:109-123. https ://doi.org/10.1007/s12403-018-0288-8

Adimalla N, Jianhua Wu (2019) Groundwater quality and associated health risks in a semi-arid region of south India: implication to sustainable groundwater management. Hum Ecol Risk Assess 25(1-2):191-216. https://doi.org/10.1080/10807 039.2018 .1546550

Adimalla N, Venkatayogi S (2017) Contamination of Fluoride in groundwater and its effect on human health: a case study in hard rock aquifers of Siddipet, Telangana State, India. Appl Water Sci 7:2501-2512. https://doi.org/10.1007/s13201-016-0441-0

Adimalla N, Venkatayogi S (2018) Geochemical characterization and evaluation of groundwater suitability for domestic and agricultural utility in semi-arid region of Basara, Telangna State,
South India. Appl Water Sci 8:44. https://doi.org/10.1007/s1320 1-018-0682-1

Badrinath SD, Raman A, Gadkari SK, Mhaisalkar VA, Despande VP (1984) Evaluation of Carbonate Stability indices for Sabarmati river water. Indian Water Assess 16:163-168

Bhardwaj V, Singh DS (2011) Surface and groundwater quality characterisation of Deoria District, Ganga Plain, India. Environ Earth Sci 63:383-395

BIS (2012). Indian Standards Specifications for drinking water. IS: 10500 2nd Revision Bureau of Indian Standards (BIS), New Delhi

Biswal AK, Kalita P (2009) Ground water scenario and its management in Shillong Urban Agglomerate, Meghalaya. In: Ramanathan AL, Bhattacharya P, Keshari AK, Bundschuh J, Chandrasekharam D, Singh SK (eds) Assessment of ground water resources and management. I K International Publishing House Pvt Ltd, New Delhi, India, pp 1-8

Camacho Suarez VV, Saraiva Okello AML, Wenninger JW, Uhlenbrook S (2015) Understanding runoff processes in a semi-arid environment through isotope and hydrochemical hydrograph separations. Hydrol Earth Syst Sci 19(10):4183-4199

Carroll D (1962) Rainwater as a chemical agent of geologic processes: a review. USGS Water Supply Paper, p 1535. https://pubs.usgs. gov/wsp/1535g/report.pdf

Chadha DK (1999) A proposed new diagram for geochemical classification of natural waters and interpretation of chemical data. Hydrogeol J 7:431-439

Devi OJ, Belagali SL, Balasubramanian A, Bose S, Senthilkumar G, Ramaswamy SN, Ramanathan AL (2009) Evaluation of Groundwater quality for irrigation and drinking purposes in selected taluks of Dakshina Kannada district in Karnataka, India. International Society of Groundwater for Sustainable Development, Special Publication, pp 301-318

Dissanayake CB, Niwas JM, Weerasooriya SVR (1987) Heavy metal pollution of the mid canal of Kandis; An environmental case study from Sri Lanka. Environ Res 42:24-35

Doneen LD (1964) Notes on water quality in agriculture. Published as a water science and engineering paper, 4001. Department of water science and engineering, University of California

Durfor CN, Becker E (1964) Public water supplies of the 100 largest cities in the United States. Geological survey water supply, vol 1812. U.S. Government Printing Office, Washington, p 364

Eaton FM (1950) Significance of carbonate in irrigation water. Soil Sci 69:123-133

Fewtrell L, Prüss-Ustün A, Bos R, Gore F, Bartram J (2007) Water, sanitation and hygiene: quantifying the health impact at national and local levels in countries with incomplete water supply and sanitation coverage. World Health Organization, Geneva

Gibbs RJ (1970) Mechanisms controlling worlds water chemistry. Science 170:1088-1090

Groundwater Information Booklet, Gulbarga District, Karnataka (2012) South-western Region. Bangalore. http://cgwb.gov.in/District_ Profile/karnataka/2012/Gulbarga-2012.pdf

Handa BK (1969) Description and classification of media for hydrogeochemical investigations. In: Symposium on ground water studies in arid and semiarid regions, Roorkee

Hem JD (1985) Study and interpretation of the chemical characteristics of natural water, 2nd edn. UG Geol Surv Water Supply Paper 2254:363

Huzefa S, Himanshu G, Ajaykumar K, Bhavana U (2020) Hydrochemical characterisation of groundwater from semi-arid region of western India for drinking and agricultural purposes with special reference to water quality index and potential health risks assessment. Appl Water Sci 10:204. https://doi.org/10.1007/s1320 $1-020-01287-z$ 
Joshi DM, Kumar A, Agrawal N (2009) Studies on physicochemical parameters to assess the water quality of river Ganga for drinking purposes in Hardiwar district. Rasayan J Chem 2(1):195-203

Kadam AK, Umrikar BN, Sankhua RN (2020) Assessment of recharge potential zones for groundwater development and management using geospatial and MCDA technologies in a semi-arid region of Western India. SN Appl Sci 2(2):312. https://doi.org/10.1007/ s42452-020-2079-7

Kelly WP (1940) Permissible composition and concentration of irrigation waters. Proc Am Soc Civ Eng 66:607-613

Lehr JH, Gass TE, Pettyjohn WA, DeMarre J (1980) Domestic Water Treatment. McGraw-Hill Book Company, New York

Li P, He X, Guo W (2019) Spatial groundwater quality and potential health risks due to nitrate ingestion through drinking water: a case study in Yan'an City on the Loess Plateau of northwest China. Hum Ecol Risk Assess Int J 25(1-2):11-31

Mohammad Muqtada AK, Kishan Raj PM, Aina M, Zakiyah AK, Hafzan EM (2018) Evaluating the suitability of shallow aquifer for irrigational purposes in some parts of Kelantan, Malaysia. Bull Geol Soc Malays 66:57-64

Mohammed-Aslam MA, Lakshmanadinesh K, Nallusamy B, Bharathkumar L, Asokan A (2016) Hydrogeochemical characteristics and classification of groundwater of Chikballapur Taluk, Karnataka. Environ Geochem 19(1-2):25-30

Nagaraju A, Muralidhar P, Sreedhar Y (2016) Hydrogeochemistry and groundwater quality assessment of Rapur Area, Andhra Pradesh, South India. J Geosci Environ Prot 4:88-99. https://doi. org/10.4236/gep.2016.44012

Ravikumar P, Venkatesharaju K, Prakash KL, Somashekar RK (2011) Geochemistry of groundwater and groundwater prospects evaluation, Anekal Taluk, Bangalore urban district, Karnataka, India. Environ Monit Assess 193:93-112

Raymond AD, Uday P (2011) Occurrence of fluoride in the drinking water sources from Gad River Basin, Maharashtra. J Geol Soc India 77:167-174

Richards LA (1954) Diagnosis and improvement of saline-alkali soils, Agriculture, handbook, vol 150. US Department of Agriculture, Washington, p 60

Rizvi SS, Aslam M (2018) Estimation of hypsometric integral and groundwater potential zones of Amarja Reservoir Catchment, Karnataka, India using SRTM data and geospatial tools. Int J Econ Environ Geol 9(2):75-85
Rizvi SS, Mohammed A (2019) Microbiological quality of drinking water in Amarja Reservoir Catchment, Aland Taluk, Karnataka, India. Curr Sci 117(1):114-121. https://doi.org/10.18520/cs/v117/ i1/114-121

Sadashivaiah C, Ramakrishnaiah CR, Ranganna G (2008) Hydrochemical analysis and evaluation of groundwater quality in Tumkur Taluk, Karnataka State, India. Int J Environ Res Public Health 5(3):158-164

Selvakumar S, Ramkumar K, Chandrasekar N, Magesh NS, Kaliraj S (2014) Groundwater quality and its suitability for drinking and irrigational use in the Southern Tiruchirappalli District, Tamil Nadu, India. Appl Water Sci 7(1):411-420

Sharath RB, Channabasappa K, Sethi C, Mohammed-Aslam MA (2018) Physical-chemical characterisation and water quality index (WQI) assessment of Bhusnoor Area, Kalaburagi District, Karnataka. J Appl Geochem 20(4):474-481

Simpson TR (1946) Saline Basin Investigation Bull Calif. Div. Water Resource, Sacramento, 52:230

Subba Rao N, Krishna Rao G (1991) Groundwater quality in Vishakhapatnam urban area, Andhra Pradesh. Indian J Environ Health 33(1):25-30

Szabolcs I, Darab C (1964) The influence of irrigation water of high sodium carbonate content of soils. In: Proceedings of 8th international congress of ISSS, Trans, vol II, pp 803-812

US Salinity Laboratory (1954) Diagnosis and improvement of salinity and alkaline soil. USA Hand Book no. 60, Wasington DC

Wilcox LV (1955) Classification and use of irrigation waters. USDA, Circular 969, Washington

World Health Organization (WHO) (2011) Valuing water, valuing livelihoods: guidance on social cost-benefit analysis of drinkingwater interventions, with special reference to small community water supplies. In: Cameron John, Hunter Paul, Jagals Paul, Pond Katherine (eds) London. England, IWA

Publisher's Note Springer Nature remains neutral with regard to jurisdictional claims in published maps and institutional affiliations. 